\title{
FISH POPULATION STATUS IN EIGHT MAJOR LAKES IN THE CLEARWATER RIVER DRAINAGE, MONTANA, 1995-2002
}

By: Rodney K. Berg

Fisheries Biologist

Montana Fish, Wildlife \& Parks
STATE DOC,IMENTS COLLETIO:

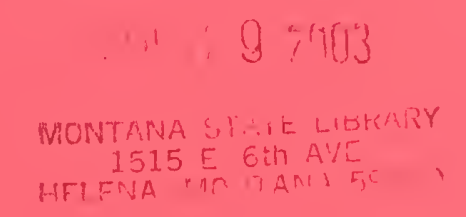

Federal Aid

Project Number: F-113-R1

F-113-R2

Project Title: Statewide Fisheries Management

Job Title: Clearwater River Drainage Fisheries Management

Date: May, 2003 


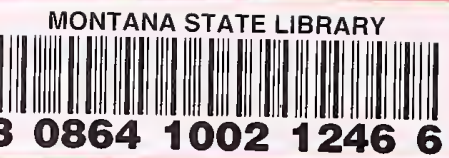




\begin{abstract}
Fish populations have been monitored on eight major lakes in the Clearwater River drainage in west central Montana since 1995. The eight major lakes include Clearwater, Rainy, Marshall, Alva, Inez, Seeley, Placid and Salmon lakes. The lakes have a combined surface area of 3,888 acres, and they support a significant and heavily utilized sport fishery.

The bulk of the sport fishery in these lakes historically was provided by kokanee, westslope cutthroat trout, brown trout, yellow perch and largemouth bass. An unwanted illegal introduction of northern pike occurred in the drainage in the late 1980's or early 1990 's. This introduction has had a profound negative impact on the fishery, reducing densities of other desirable fish species by 70 to over 90 percent. Problems and strategies associated with management of the sport fishery in the presence of northern pike population expansion are discussed.
\end{abstract}


Digitized by the Internet Archive in 2015 


\section{INTRODUCTION}

A basic inventory is essential in formulating management plans for maintaining and utilizing a fishery. Seldom is this information complete for an entire area or drainage. Streams and lakes in the Clearwater River drainage in west central Montana support a significant and heavily utilized sport fishery. Prior to this study, basic data on the aquatic resources of this area were lacking.

Unwanted illegal fish introductions, increasing subdivision and human encroachment on lands adjacent to streams and lakes, and increasing fishing and recreational use of all waters were beginning to affect fish populations in the Clearwater River drainage. For these reasons the Montana Department of Fish, Wildlife and Parks (MFWP) initiated this study on July 1, 1995. Without basic inventory data, little could be done to evaluate conflicting resource demands and minimize adverse impacts on the aquatic resource.

\section{DESCRIPTION OF STUDY AREA}

The Clearwater River drainage lies in west central Montana, and is the principal tributary of the Blackfoot River. Eight major lakes in the drainage are commonly referred to as the "Clearwater Chain of Lakes". These lakes include Clearwater, Rainy, Marshall, Alva, Inez, Seeley, Placid and Salmon lakes (Figure 1). Principal streams in the drainage include the Clearwater River, which originates at the outlet of Clearwater Lake, East and West Forks of the Clearwater River, and Morrell, Owl, Placid, Deer, Trail and Blanchard creeks. Important smaller lakes in the drainage include Harpers, Blanchard, Elbow, Elsina, Dinah, Spook and Hidden lakes.

\section{TECHNIQUES}

\section{Lake Morphometry}

Morphometric data was collected on the eight major lakes in the Clearwater River drainage during the ice free period in 2002. Bathymetric maps were developed for each lake with $5 \mathrm{ft}$ contour intervals using hydroacoustic and GPS instrumentation. Physical characteristics measured for each lake included surface area, lake volume, aquatic weed surface area, maximum depth and elevation.

\section{Gill Nets}

Fish were sampled with standard "Montana" experimental floating and sinking nylon or monofilament gill nets $6 \times 125 \mathrm{ft}$ with graduated mesh size from $3 / 4$ to 2 inches square measure. Overnight stationary sets with these nets generally produced good catches of a wide variety of fish species. The nets were equally distributed around the entire perimeter of each lake each year to produce a representative catch. 



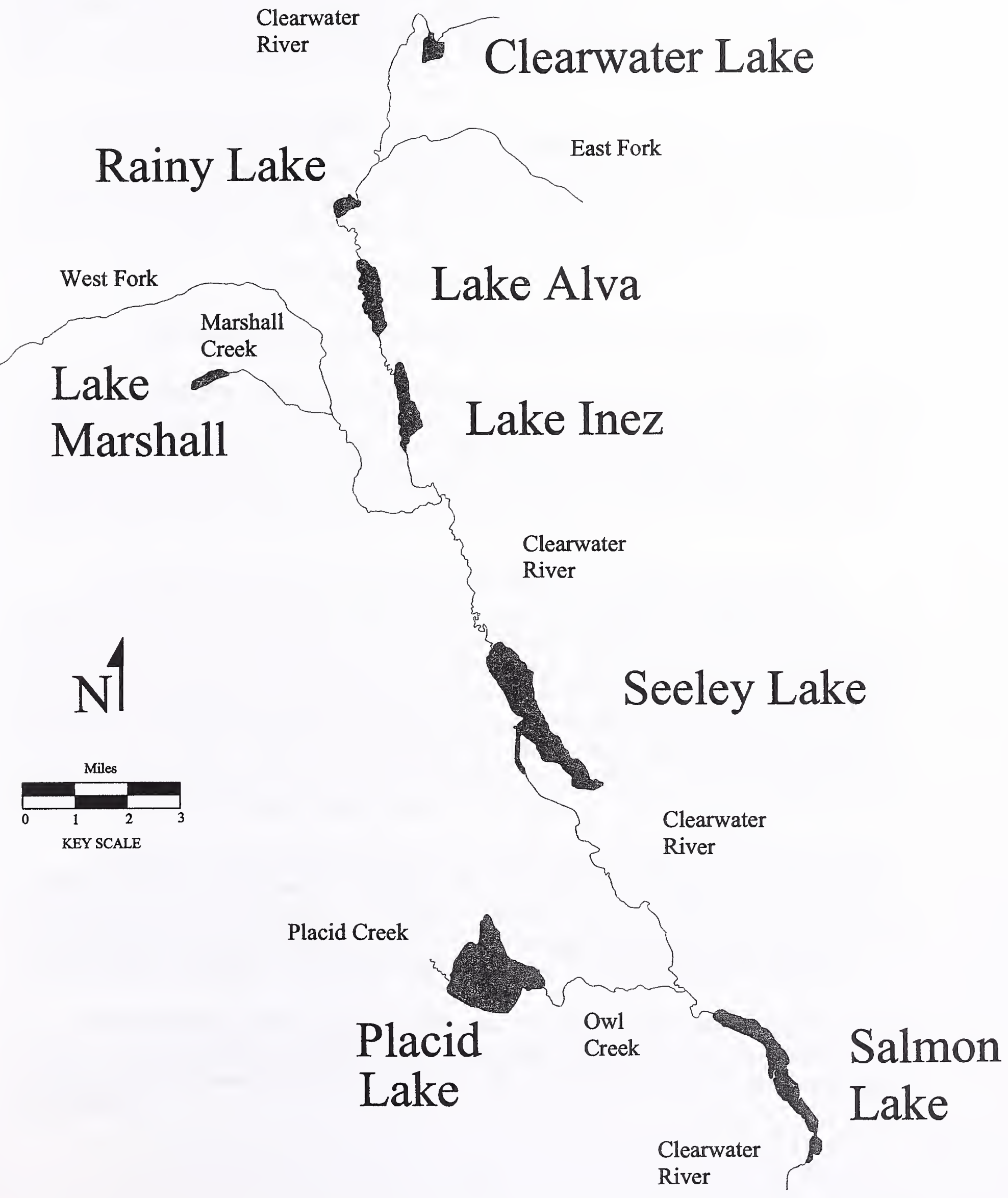

Figure 1. A map of the Clearwater River drainage depicting the location of the eight major lakes. 

During the present study 15 to 60 gill net sets were made each year in each lake. The number of gill nets set in each lake depended on the size and complexity of the lake. Gill netting was continued each year on each lake until catch statistics stabilized around a mean. The locations of each gill net set were marked on USGS topographic maps each year. In addition, GPS coordinates for each gill net set were recorded for future reference.

\section{Fish Sample Processing and Tagging}

Sampled fish were measured to the nearest millimeter in total length, and weighed to the nearest 10 grams. Sex and spawning condition (gravid, ripe or spawned) were recorded for fish captured during their spawning period. Several game fish species were marked with individually numbered Floy T-tags to evaluate growth rate, movement and angler harvest.

\section{FINDINGS, RESULTS AND DISCUSSION}

\section{Lake Morphometry, Physical Characteristics and Limnological Conditions}

The eight major lakes in the Clearwater River drainage have a combined surface area of 3,888 acres (Table 1). Placid Lake, the largest lake in the drainage has a surface area of 1,300 acres and a volume of 64,215 acre-ft. The smallest of the eight major lakes, Rainy Lake, is 81 acres in surface area and 1,420 acre- $\mathrm{ft}$ in volume. Maximum lake depths range from $125 \mathrm{ft}$ in Seeley Lake to $29.4 \mathrm{ft}$ in Rainy Lake. Lake elevations range from 4,786 ft MSL at Clearwater Lake to 3,909 $\mathrm{ft}$ MSL at Salmon Lake.

The eight major lakes are becoming increasingly more eutrophic due to nutrient enrichment associated with an increasing human population residing and recreating in the drainage. Rooted aquatic vegetation enhanced by nutrient enrichment presently occupies 265.32 acres, or 6.8 percent, of the total surface area of the lakes. Long time local residents indicate rooted aquatic weeds have consistently increased over time in the past 40 to 50 years. Summer algae blooms have been increasing particularly in Inez, Placid and Salmon lakes and to some extent in Seeley Lake. Winter fish kills associated with dissolved oxygen depletion related to weed and algae decomposition occur in Placid Lake. Toxic algae blooms have resulted in fish kills in Salmon and Inez lakes in late summer and early fall.

Bathymetric maps developed in 2002 for the eight major lakes in the Clearwater River drainage are shown in Appendix 1. Mapping of rooted aquatic vegetation reveals its growth occurs only in depths of up to 20 feet. Aquatic vegetation densities will be reevaluated next year to determine how much of each lake's surface area less than 20 feet in depth is occupied by rooted aquatic vegetation. This will provide a better index of eutrophication for each lake.

Since human population densities and nutrient enrichment continue to increase, little can be done to retard increased growths of unwanted aquatic weeds and algae. Improvement of septic systems for human dwellings in close proximity to lakes and streams would help mitigate the problem. 

Table 1. Physical characteristics of the eight major lakes in the Clearwater River drainage.

\begin{tabular}{|l|c|c|c|c|c|}
\hline \multicolumn{1}{|c|}{ Lake } & $\begin{array}{c}\text { Surface } \\
\text { Acres }\end{array}$ & $\begin{array}{c}\text { Volume } \\
\text { Acre-Feet }\end{array}$ & $\begin{array}{c}\text { Weed Area } \\
\text { Acres }\end{array}$ & $\begin{array}{c}\text { Maximum } \\
\text { Depth Feet }\end{array}$ & $\begin{array}{c}\text { Elevation } \\
\text { Feet MSL }\end{array}$ \\
\hline Clearwater & 103 & 2,087 & 12.33 & 42 & 4786 \\
\hline Rainy & 81 & 1,420 & 8.97 & 29.4 & 4094 \\
\hline Marshall & 85 & 2,700 & 5.21 & 57 & 4751 \\
\hline Alva & 314 & 15,477 & 8.45 & 90.1 & 4074 \\
\hline Inez & 298 & 11,577 & 17.1 & 74 & 4061 \\
\hline Seeley & 1,047 & 58,853 & 62 & 125 & 3993 \\
\hline Placid & 1,300 & 64,215 & 120.65 & 92.6 & 4123 \\
\hline Salmon & 660 & 20,341 & 30.61 & 64.8 & 3909 \\
\hline \multicolumn{1}{|c|}{ TOTAL } & 3,888 & 176,670 & 265.32 & & \\
\hline
\end{tabular}



Fish Population Status and Management

Relative abundances of fish populations in the eight major lakes in the drainage have been monitored since 1995 by experimental gill netting. Results of these surveys are shown in Figures 2 through 14, Tables 2 through 7 and Appendix 2.

The bulk of the sport fishery in these lakes historically was provided by kokanee, westslope cutthroat trout, brown trout, yellow perch and largemouth bass along with a few bull and rainbow trout. Mountain whitefish provided an underutilized sport fishery. An unwanted illegal introduction of northern pike occurred in the drainage in the late 1980's or early 1990's. Expansion of the pike population has had a detrimental impact on the diverse sport fishery which existed prior to their introduction. In several lakes, including Salmon, Inez and Seeley, northern pike are providing an increasing or dominant proportion of the sport fishery.

Northern pike were detected in gill net surveys at high densities at the onset of studies initiated in 1995 on Salmon and Inez lakes (Figures 5 and 8) and at a low density in Lake Alva (Figure 11). Following a relatively high water year in 1997, northern pike moved into Seeley Lake as a result of upstream movement in the Clearwater River from Salmon Lake and/or downstream movement in the Clearwater River from Lake Inez (Figures 2 and 3). Northern pike reproduction was detected 1999, and the population is presently established in Seeley Lake at a high density.

Northern pike population density increases in Seeley, Salmon and Inez lakes have had profound negative impacts on other game and nongame species (Figures 4,7 and 10). Northern pike predation depleted populations of other species which provided their food supply by 1995 in Salmon and Inez lakes and, in response to depletion of their food supply, northern pike declined in density in each subsequent year through 1999 (Figures 5 and 8). Recovery of kokanee, trout and other species densities in these lakes occurred as northern pike declined in abundance, but this, in turn, has led to a recovery and subsequent increase in northern pike densities.

It is apparent that population densities of northern pike and other species in Salmon, Inez and Seeley lakes will vary significantly as northern pike go through cycles of population expansion and contraction related to availability of their food supply which, in part, consists of other game fish species of considerable importance to anglers.

Westslope cutthroat trout and kokanee populations in the Clearwater drainage lakes are presently enhanced by hatchery supplementation. Hatchery plants were significantly decreased or eliminated in the pike infested lakes, including Salmon, Inez and Seeley, during northern pike population density expansion periods. Some hatchery supplementation was resumed as pike reached significantly reduced densities in Salmon and Inez lakes to determine whether a diverse fishery could be provided periodically in these lakes. Additional sampling and data analysis are needed to evaluate this management strategy. 

Northern pike were illegally introduced into Lake Alva prior to the inception of this study. Pike were detected at very low densities in gill net surveys conducted in 1995 and 1998, but have not been observed in sampling since 1998. It appears northern pike population survival has failed in Lake Alva, probably due to failure of the population to reach a critical mass and successfully reproduce. Suitable habitat exists for northern pike population expansion in Lake Alva, and the lake could eventually succumb to fishery degradation if northern pike are reintroduced by human endeavor (bucket biologists) or movement upstream in the Clearwater River from Lake Inez. Movement of northern pike and other species from Lake Inez to Lake Alva through the Clearwater River is presently severely hindered, if not precluded, by extensive beaver dams. A high flood breaching these dams could result in movement of northern pike from Lake Inez to Lake Alva, the expansion of northern pike in Alva and the collapse of the exceptionally valuable kokanee/westslope cutthroat trout fishery which presently exists in this lake.

Placid Lake is presently free of northern pike due, in part, to the outlet structure on the lake which precludes movement of northern pike from Salmon or Seeley lakes through the Clearwater River and Owl Creek and into Placid Lake. However, the outlet structure on Placid Lake will be breached during a high flood at some time in the future, and northern pike could be introduced into Placid Lake at that time. Feasibility of a man-made barrier to northern pike passage in the bypass channel around the outlet structure should be evaluated to eliminate or reduce the potential for an undesired introduction of northern pike into Placid Lake by movement of fish from infested lakes.

Clearwater, Rainy and Marshall lakes are also presently pike free. A man-made fish barrier in the Clearwater River downstream from Rainy Lake, commonly referred to as the Rainy Lake fish barrier, precludes movement of northern pike from lower elevation lakes into Rainy and Clearwater lakes. Natural fish barriers prevent northern pike movement into Marshall Lake. These three lakes are presently managed as westslope cutthroat/bull trout fisheries, and they are the only three of the eight major lakes which do not contain kokanee.

In the 1960's MFWP installed two fish barriers in the Clearwater River drainage. The lower barrier, on the Clearwater River downstream of Lake Inez, is commonly referred to as the Lake Inez fish barrier. The upper, or Rainy Lake fish barrier, is located on the Clearwater downstream of Rainy Lake. The barriers, in conjunction with chemical rehabilitation of lakes upstream of the barriers, constituted an attempt to eliminate yellow perch, then considered an undesirable species, and enhance salmonid populations. This reclamation effort was not successful in eradication of yellow perch, but it was unintentionally successful in eliminating northern pikeminnows and peamouth in lakes upstream from the barriers.

Westslope cutthroat trout survival and population densities are presently substantially enhanced in Inez, Alva, Rainy, Marshall and Clearwater lakes apparently due to lack of predation by or food competition with northern pikeminnows and peamouth (Tables 2 through 7). Inez, Alva and Clearwater lakes are presently supplemented with hatchery westslope cutthroat trout which significantly enhances natural recruitment. Westslope cutthroat trout in Rainy and Marshall 

lakes persist entirely due to natural reproduction, but their present densities appear low when compared to hatchery supplemented lakes. In an attempt to improve westslope cutthroat trout densities in Rainy and Marshall lakes, hatchery supplementation was resumed in these lakes in 2003.

\section{CONCLUSIONS}

An unwanted illegal introduction of northern pike is, by far, the largest factor impairing fish populations in lakes in the Clearwater River drainage. Northern pike population expansions in Inez, Salmon and Seeley lakes have reduced other desirable fish species densities by 70 to over 90 percent.

Of particular concern are westslope cutthroat trout and bull trout. Currently, bull trout are listed as a Threatened Species under the Endangered Species Act, and westslope cutthroat trout are considered a sensitive species by Region 1 of the Forest Service and a Species of Special Concern by MFWP. While westslope cutthroat populations in lakes in the Clearwater River drainage can be supported by hatchery supplementation, this management option is not available for bull trout. Bull trout have been reduced in density by over 90 percent in Inez and Seeley lakes, and they are nearly extinct in Salmon Lake due to northern pike predation and competition.

Northern pike presently occupy three lakes, Salmon, Inez and Seeley, which collectively constitute 2,005 acres, or 52 percent, of the total lake surface area in the Clearwater River drainage. Alva and Placid lakes are vulnerable to northern pike introduction during a high runoff year due to upstream movement of pike from infested lakes. If this were to occur, northern pike would occupy 3,619 acres, or 93 percent, of the total lake surface area in the drainage. Little could be done to provide a diverse fishery under these circumstances. Significant efforts should be made to insure northern pike introduction does not occur in Placid and Alva lakes.

Angler preference and creel surveys have been conducted in the Clearwater drainage. These surveys indicate anglers strongly prefer the diverse sport fishery which exists in pike free lakes and which existed previously in lakes now infested with northern pike. For these reasons, fishing pressure has shifted significantly from pike infested lakes, Seeley, Salmon and Inez, to pike free lakes, Placid, Alva, Clearwater, Rainy and Marshall.

Hatchery supplementation of westslope cutthroat trout has been resumed or increased in all of the pike free lakes in an effort to accommodate increased fishing pressure and maintain angler satisfaction. For the same reasons hatchery supplementation of kokanee has been increased in Alva and Placid lakes to maintain angler satisfaction for this highly sought after species.

Kokanee do not occur and have never been planted in Clearwater, Rainy or Marshall lakes. It would not be prudent to ever plant kokanee in these lakes since they may not be large enough to support desirable populations. In addition, and more importantly, kokanee appear to suppress westslope cutthroat trout population densities due to competition for food, primarily zooplankton, 

at early life stages. Additional data, analysis and conclusions pertaining to kokanee/westslope cutthroat trout relationships will be presented in a future report.

Increased fishing pressure on all of the pike free lakes in the drainage has become increasingly problematic in recent years, and is particularly evident on Rainy and Clearwater lakes. Kokanee and westslope cutthroat trout population densities and angler catch rates can be maintained up to a certain point by increased hatchery supplementation. However, angler satisfaction with any fishery is also dependent on whether anglers feel over crowded. Over crowding is becoming an increasingly significant issue on Rainy and Clearwater lakes. Use of these lakes has been restrained to some extent by Forest Service efforts which have included minimizing road signs identifying the lakes and not increasing the size of parking areas. These management policies should be continued.

In summary, northern pike introductions in the Clearwater drainage have created significant fishery and recreational management problems. MFWP will continue to endeavor to provide a diverse fishery in an effort to meet recreational expectations through use of hatchery supplementation, salmonid habitat protection or enhancement, efforts to prevent additional unwanted introductions of exotic species, and other management strategies. 



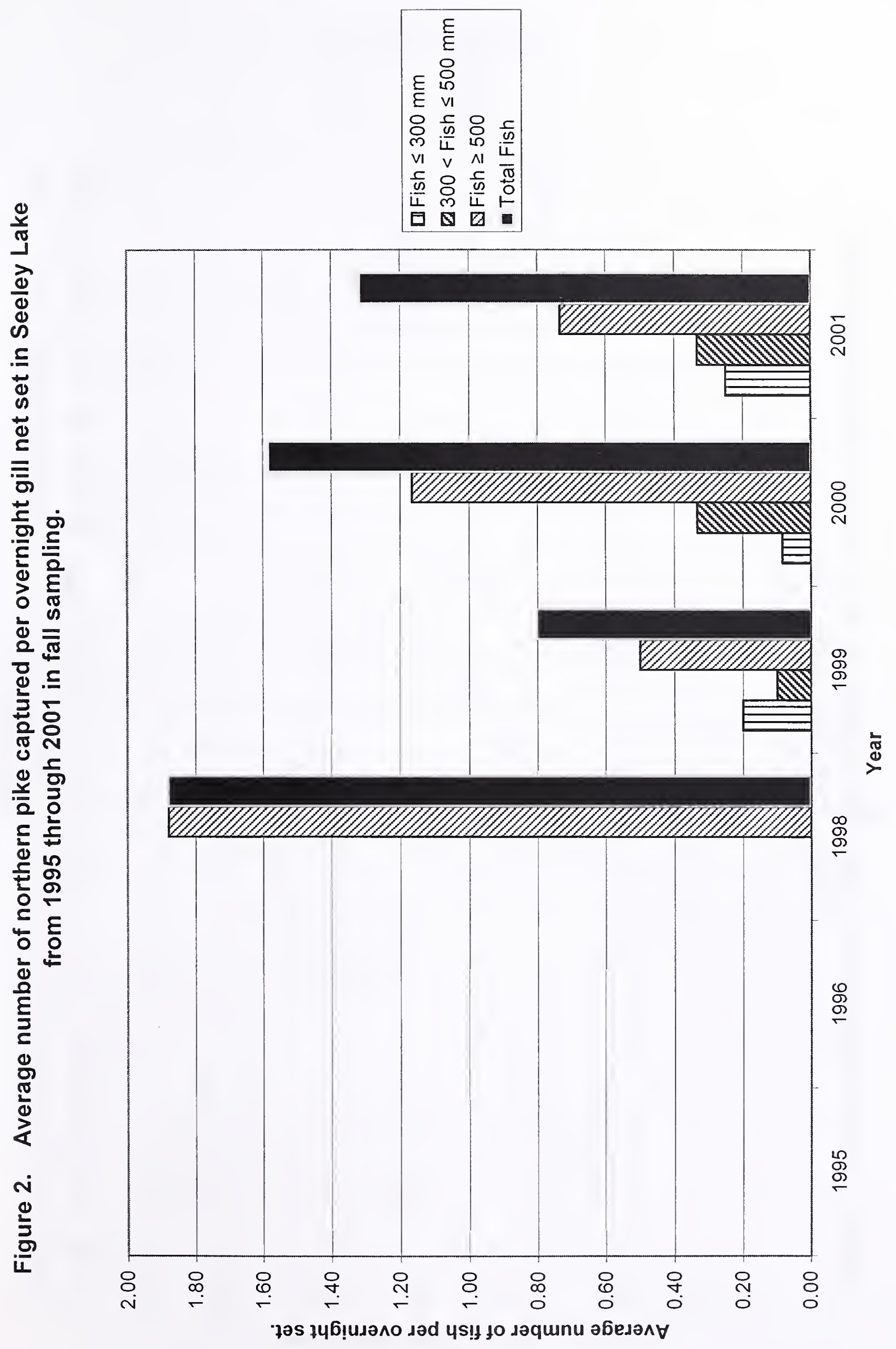




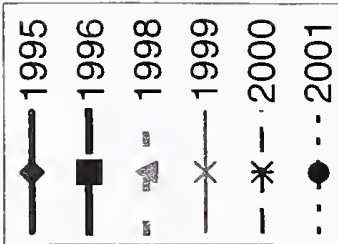

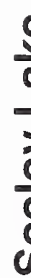

등

을

Ф

하

$\bar{\pi}$

드

웅

这

(1)

으

든

흥 는

吅

추

ฮ

ซ్

등

लं

는

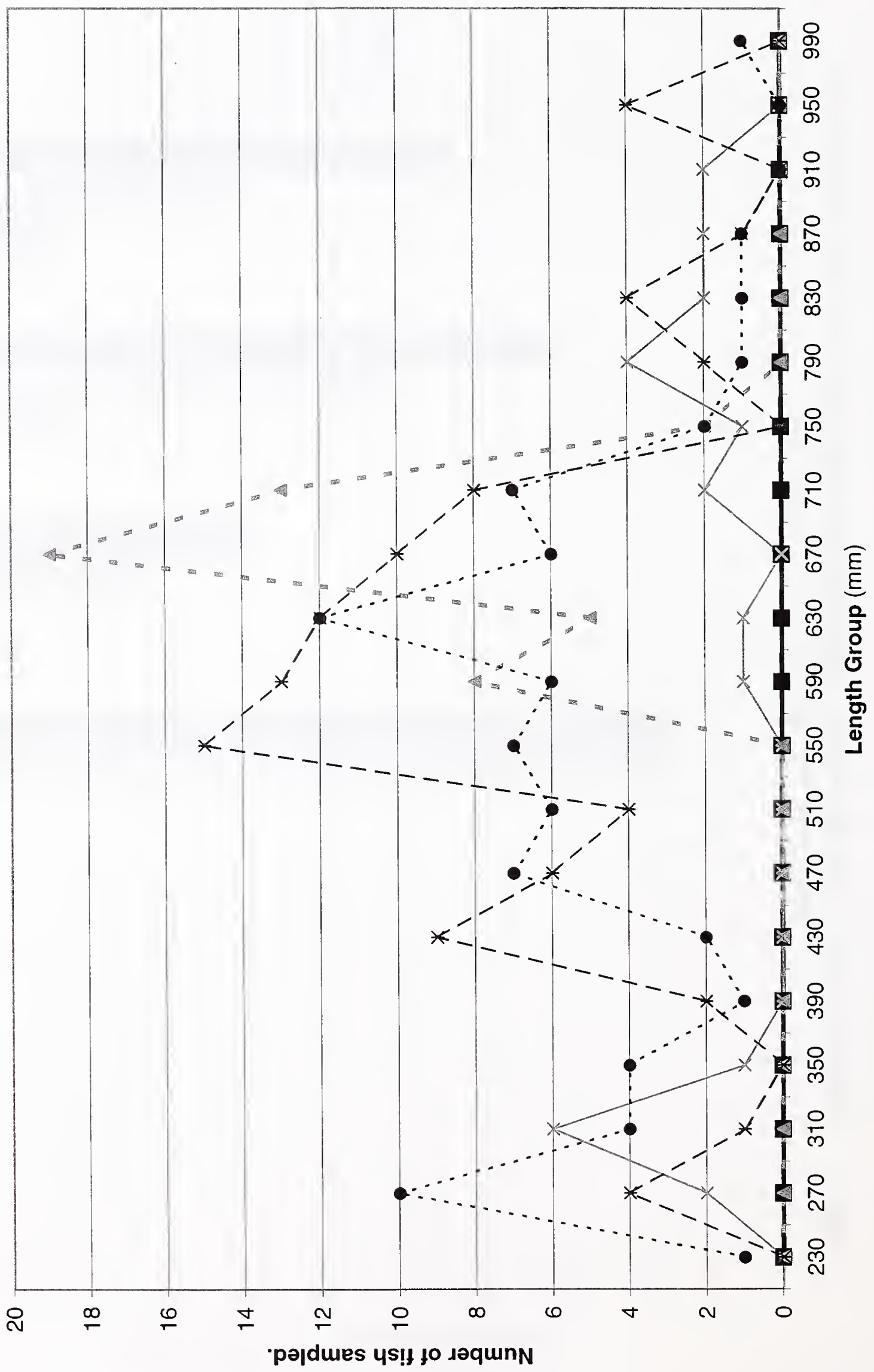




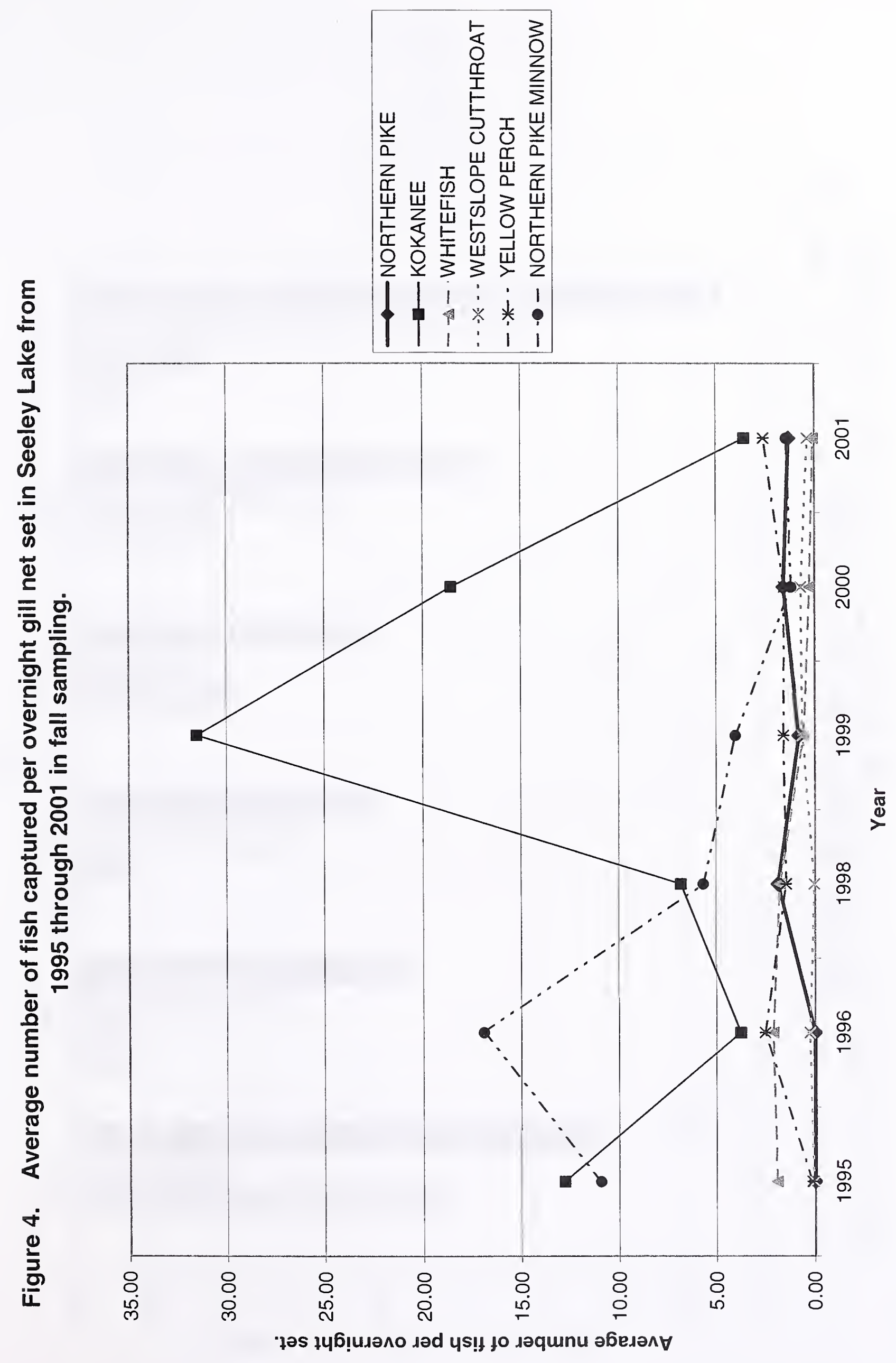




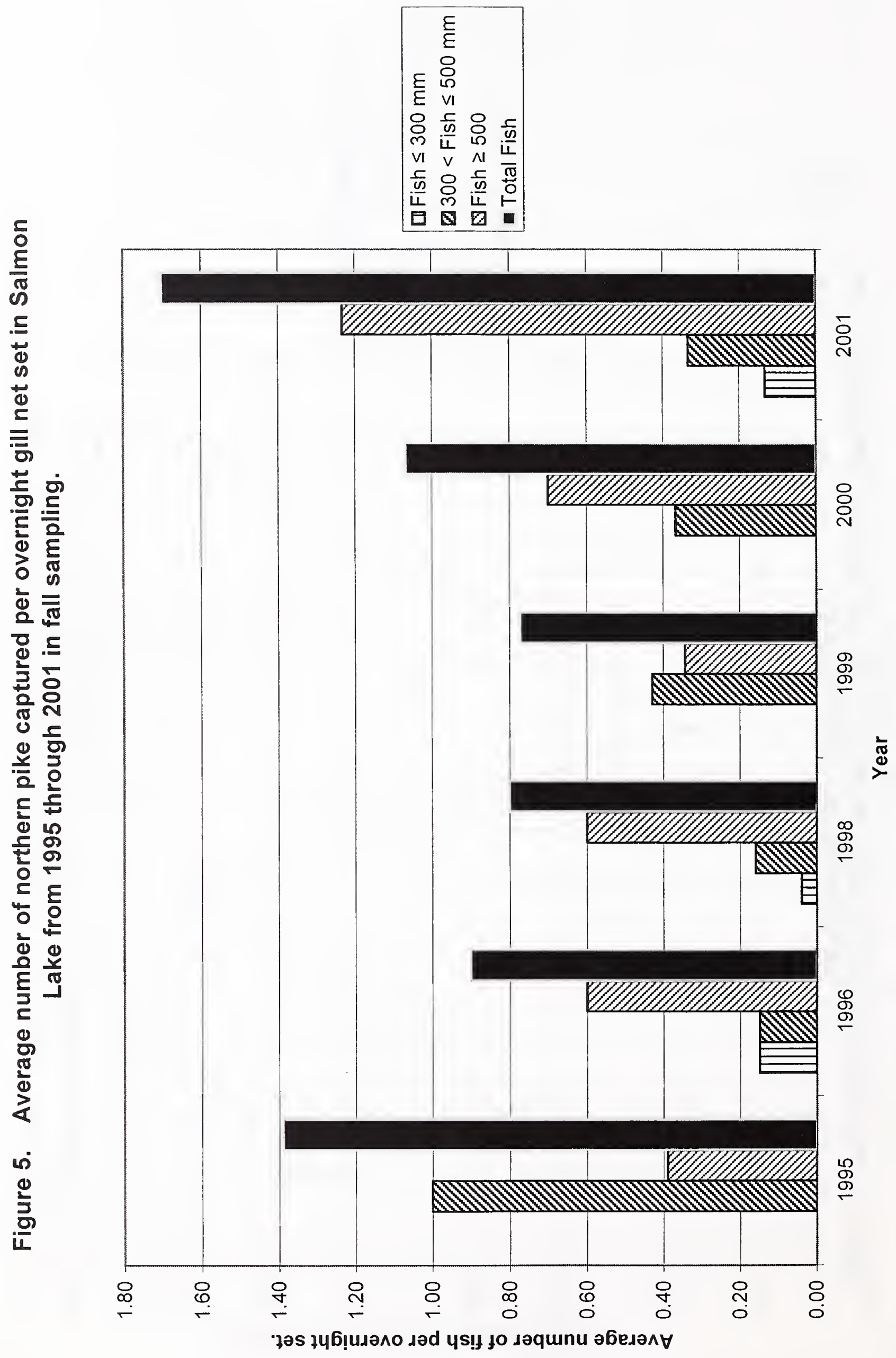



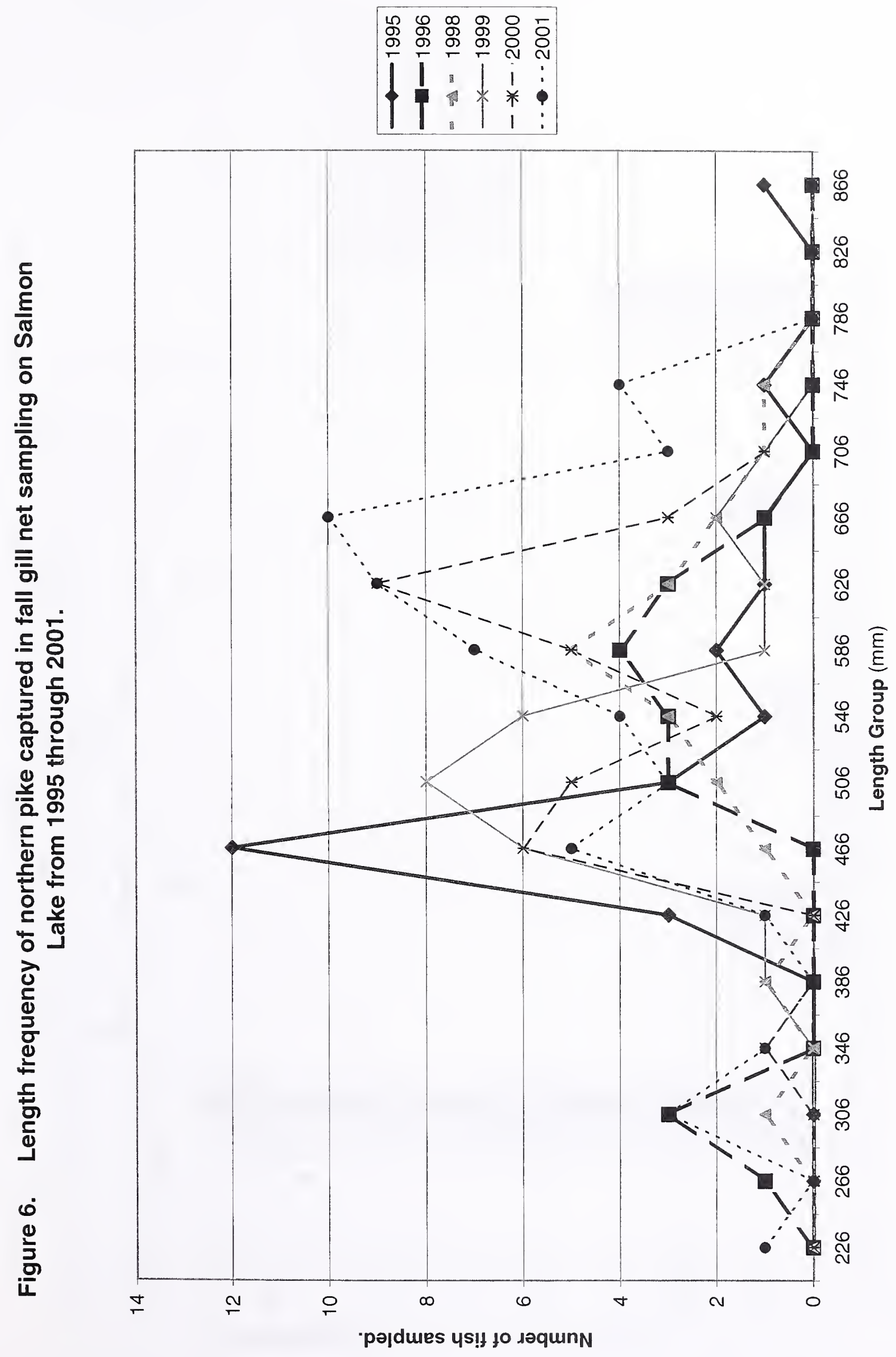


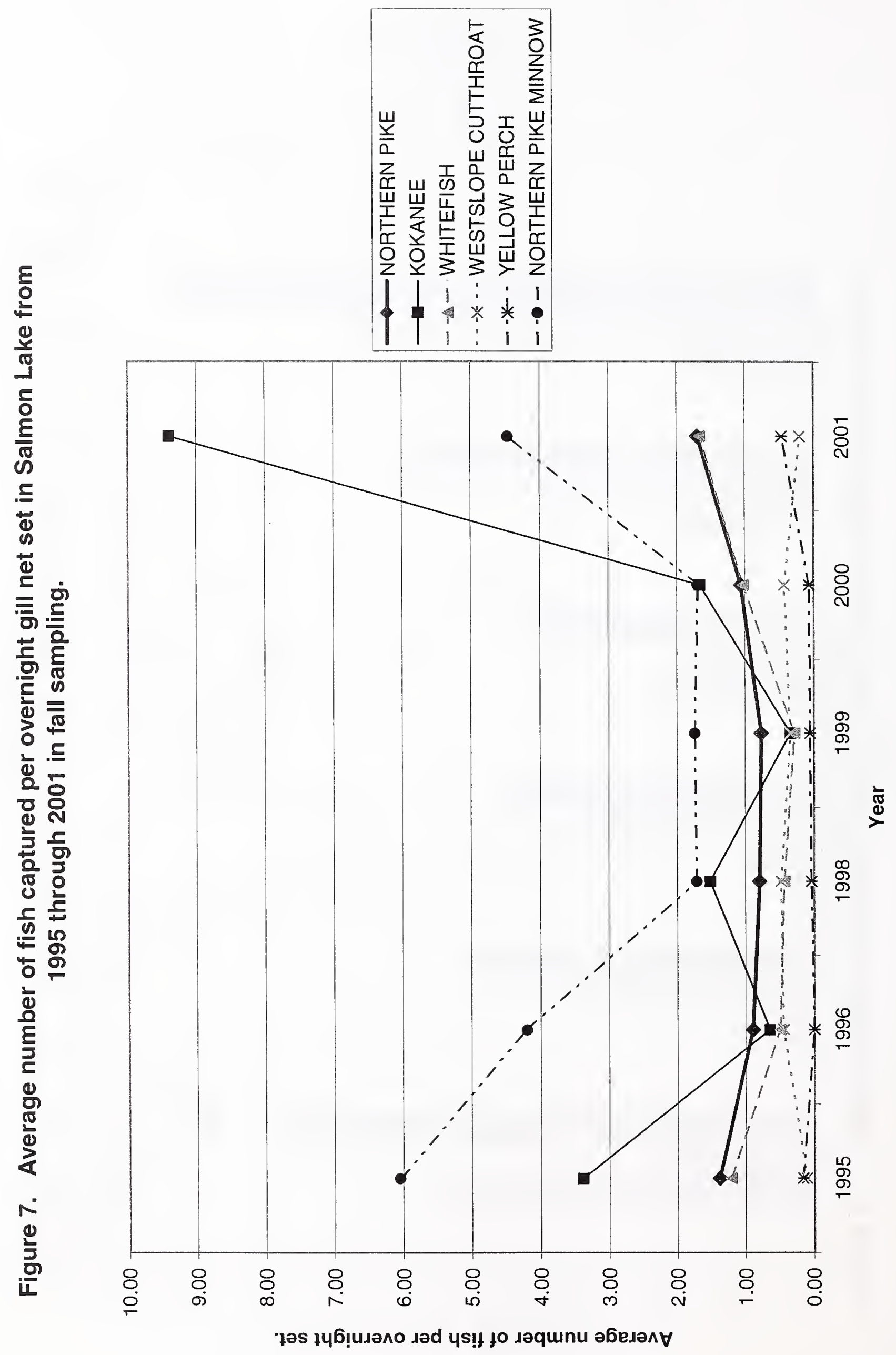




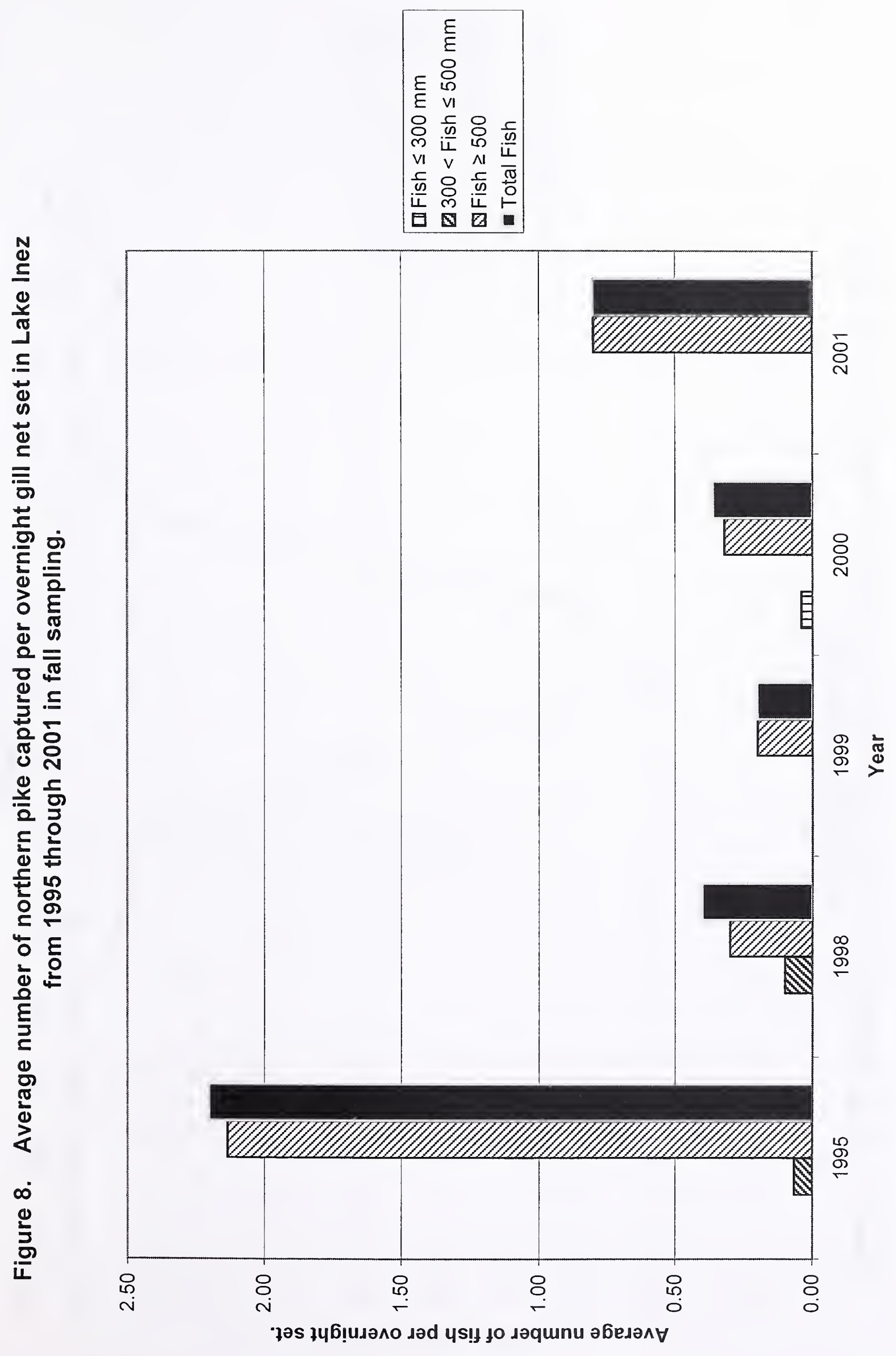



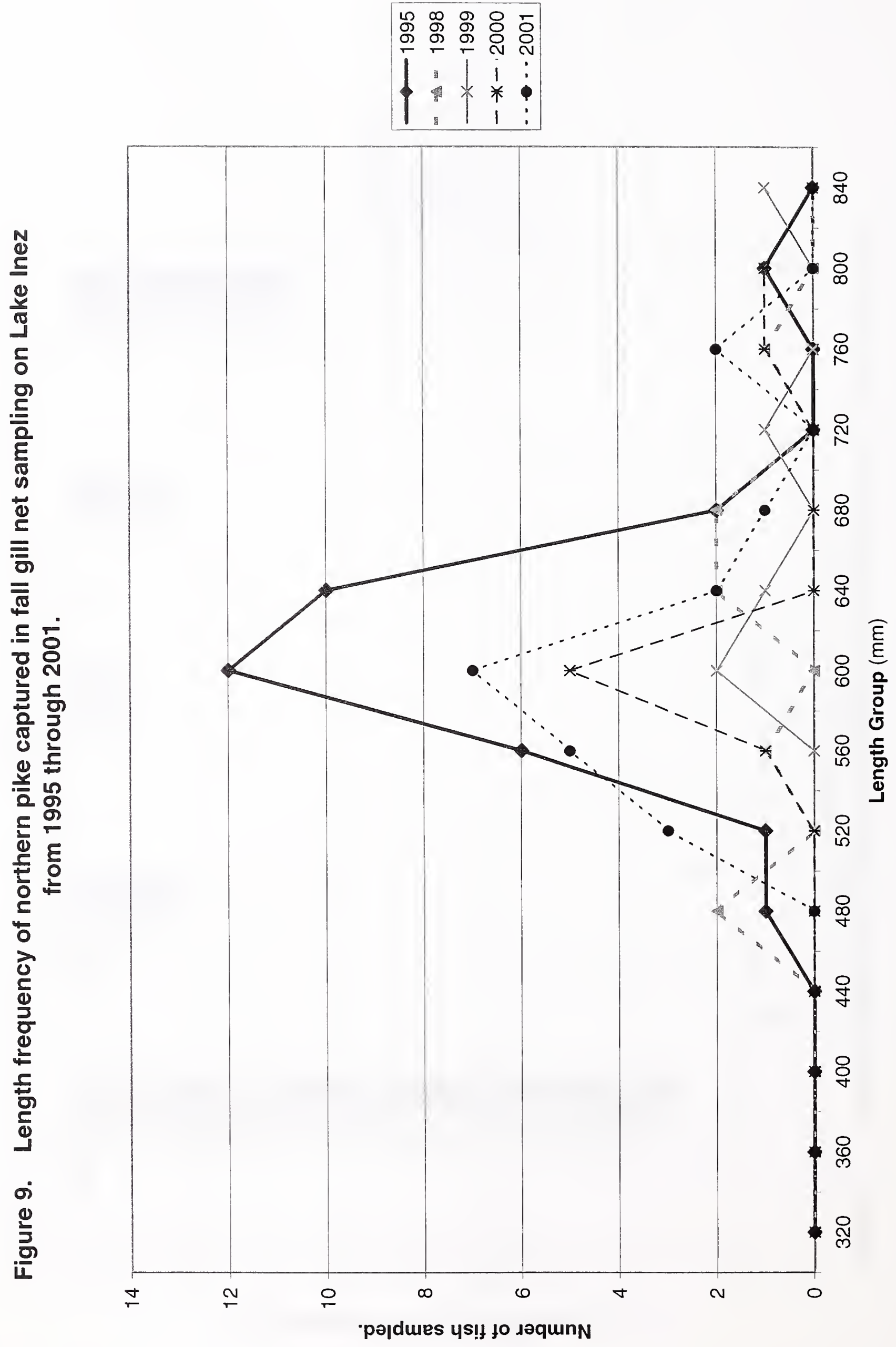


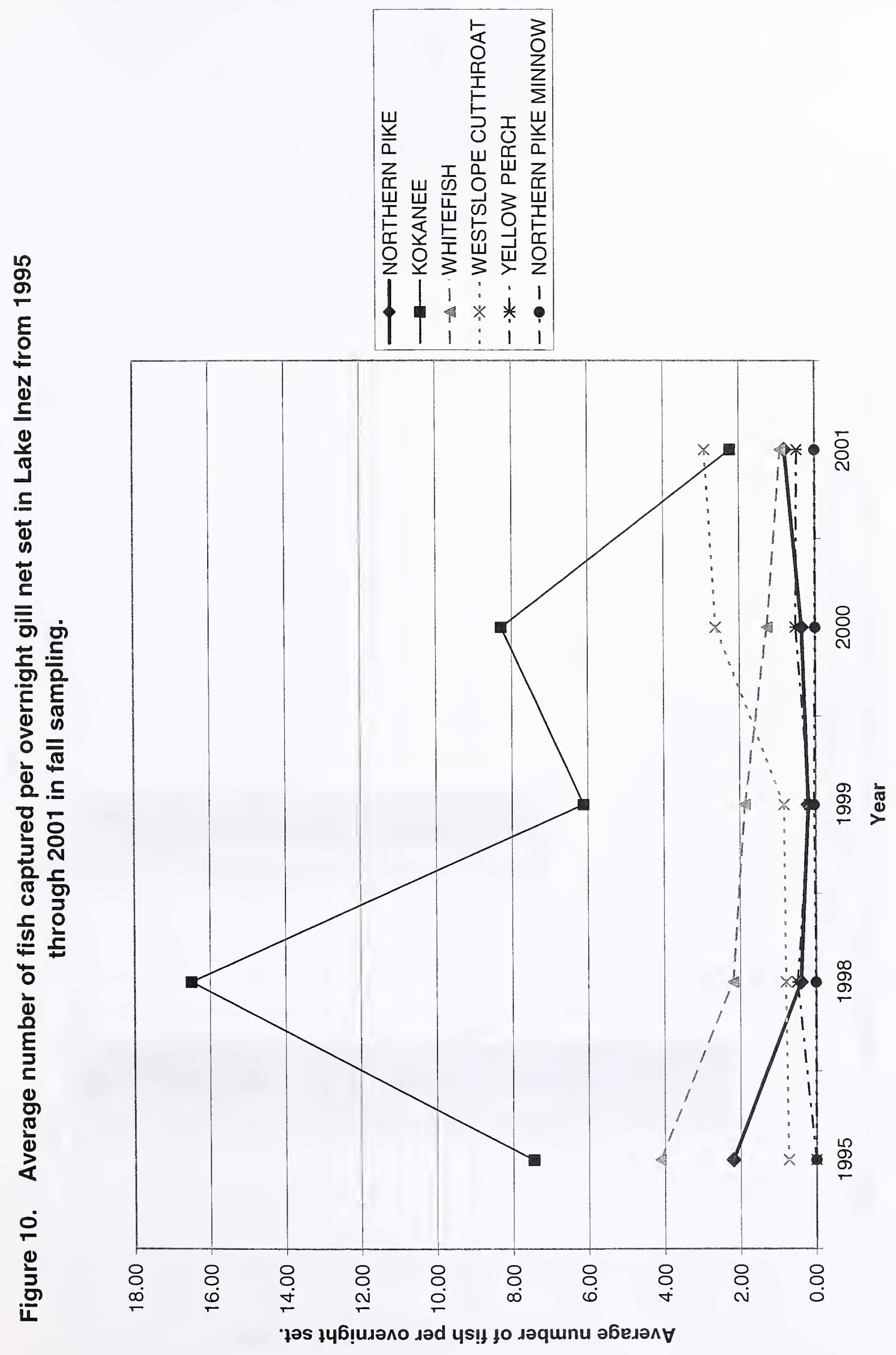




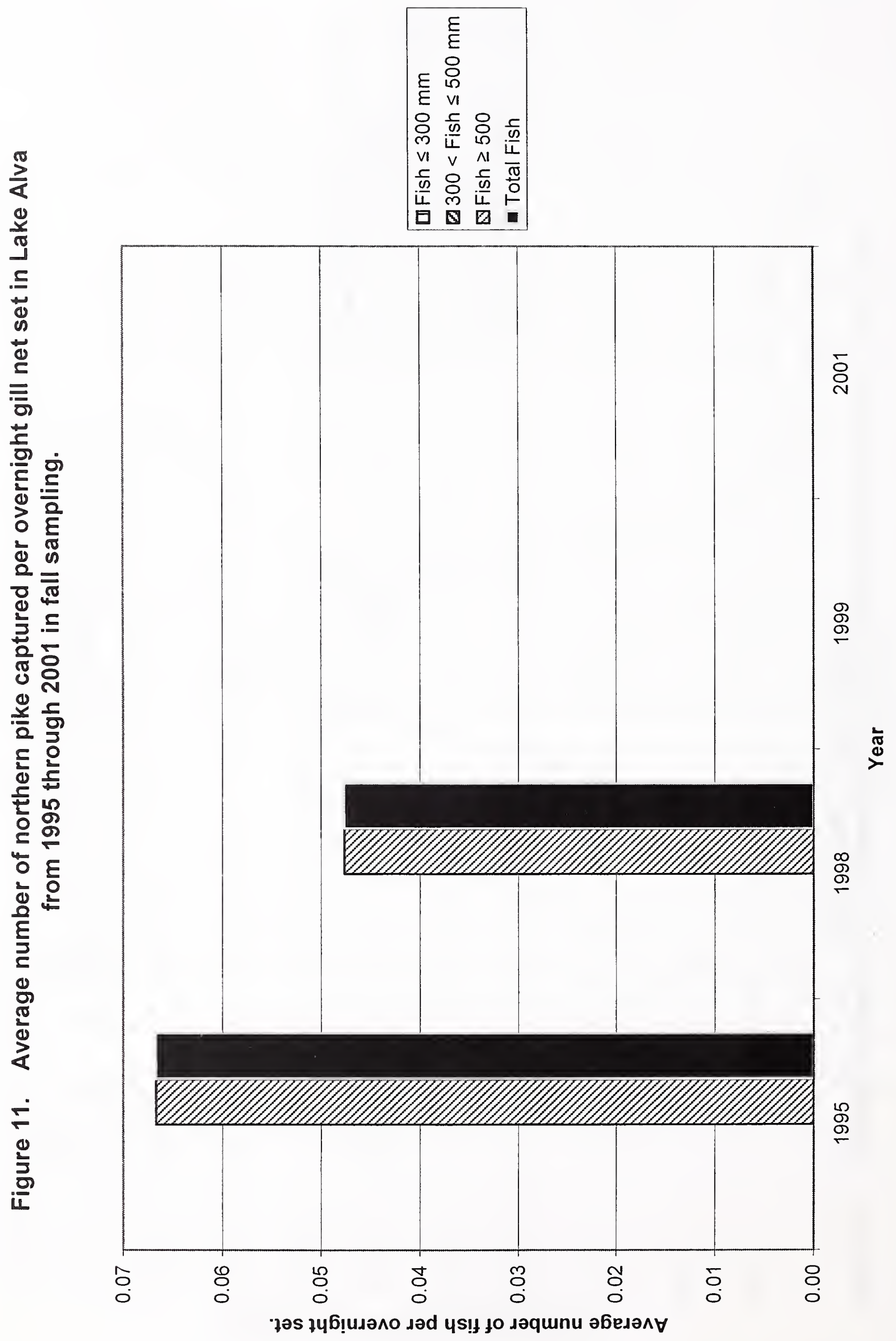



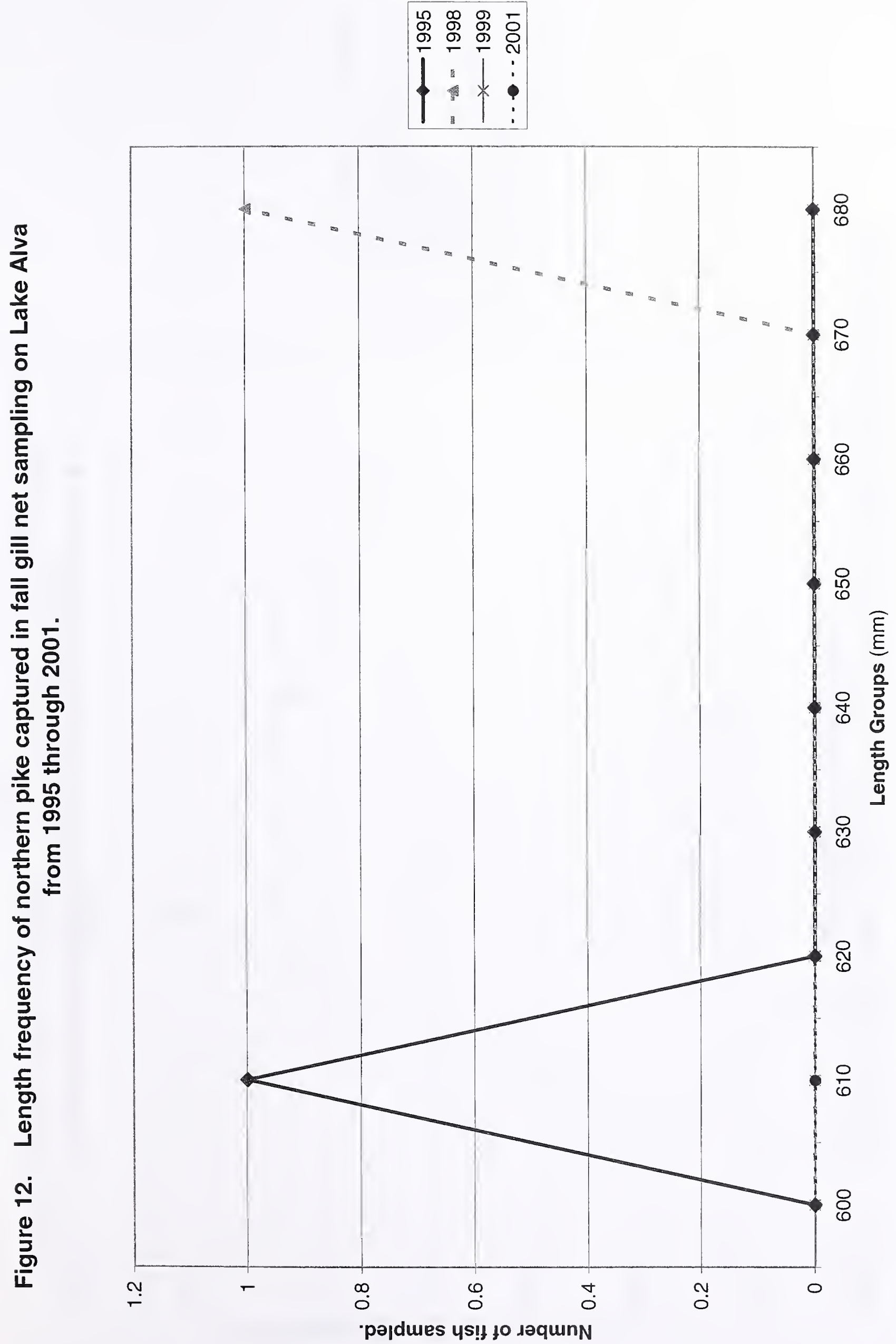


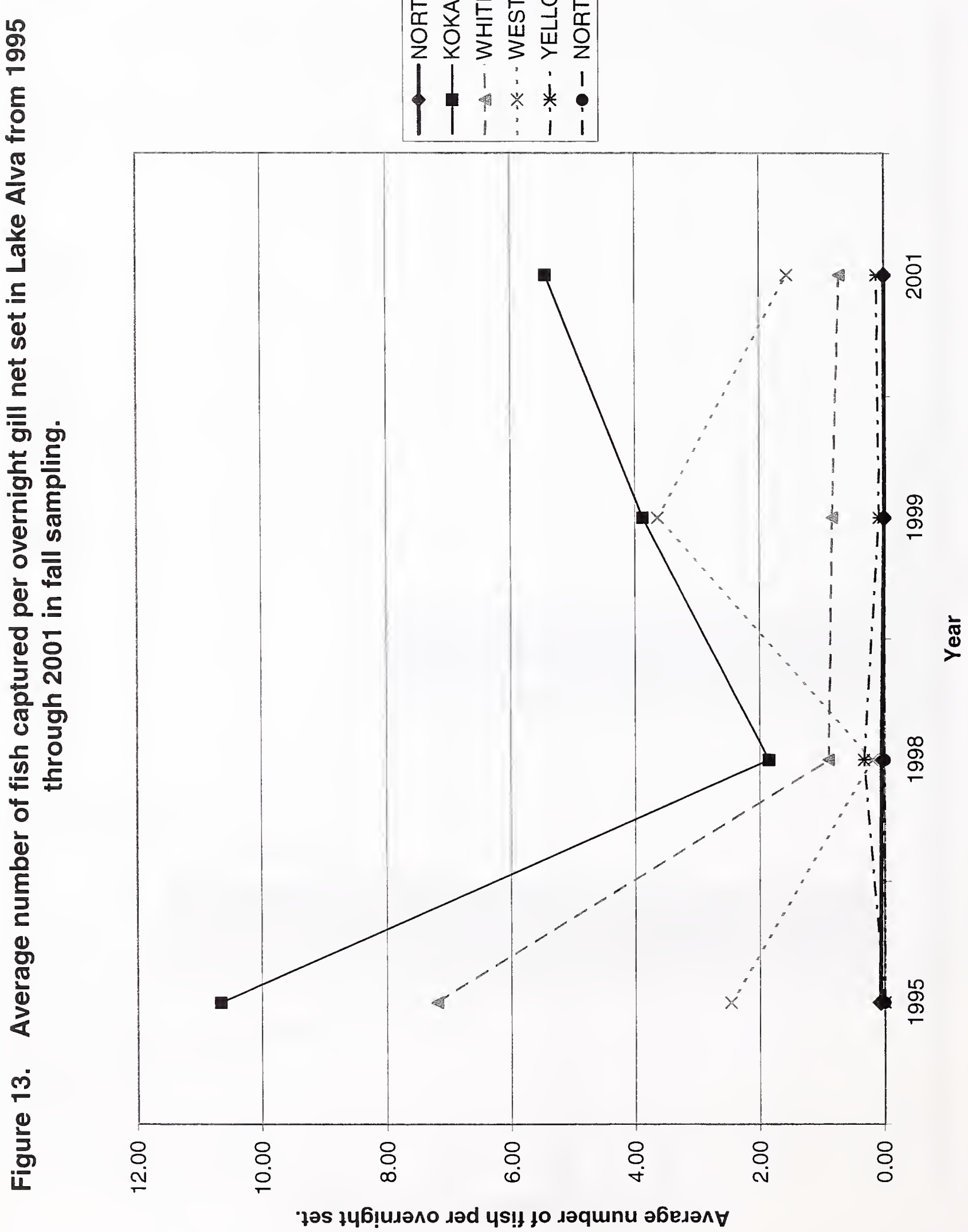




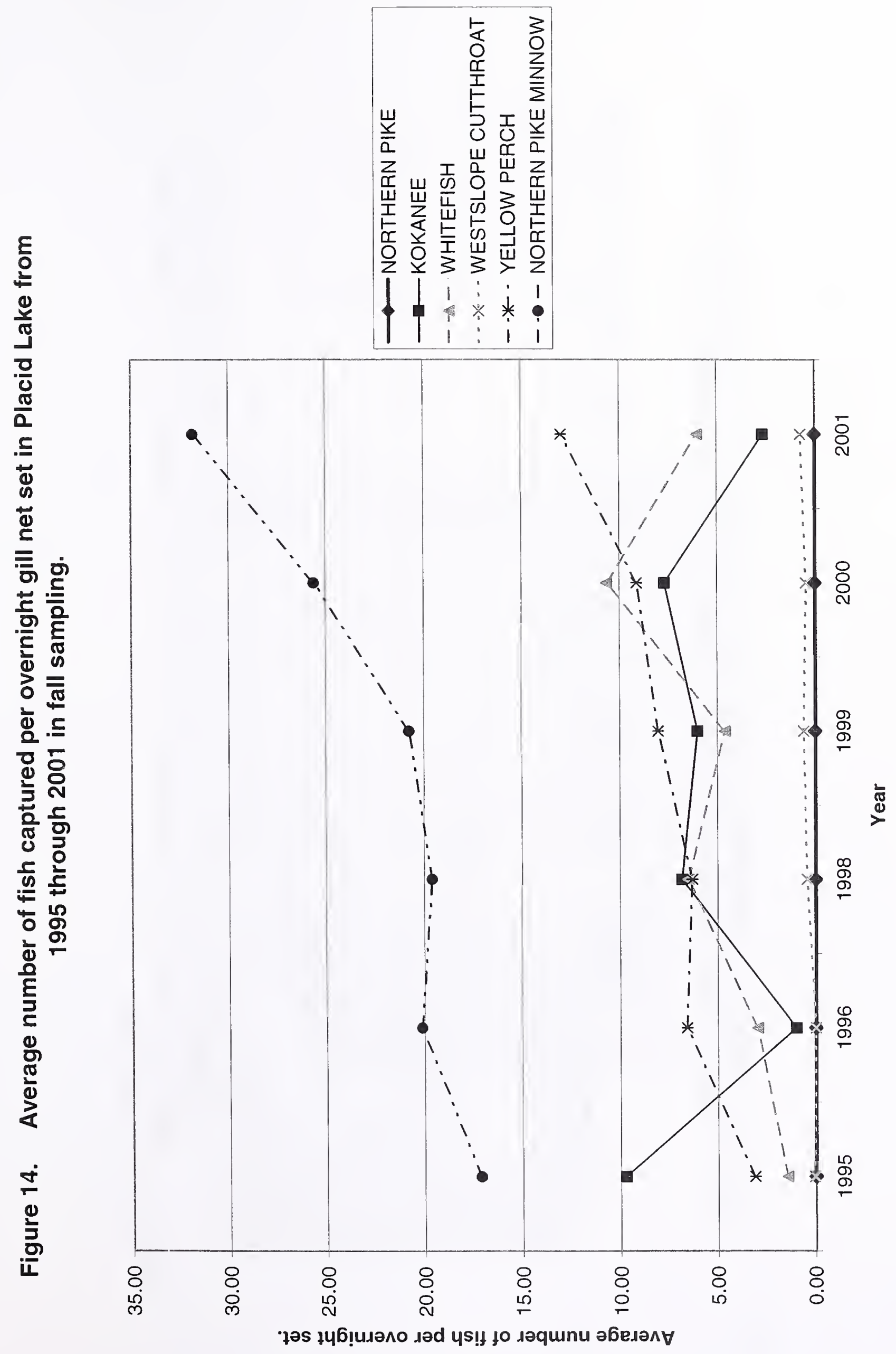




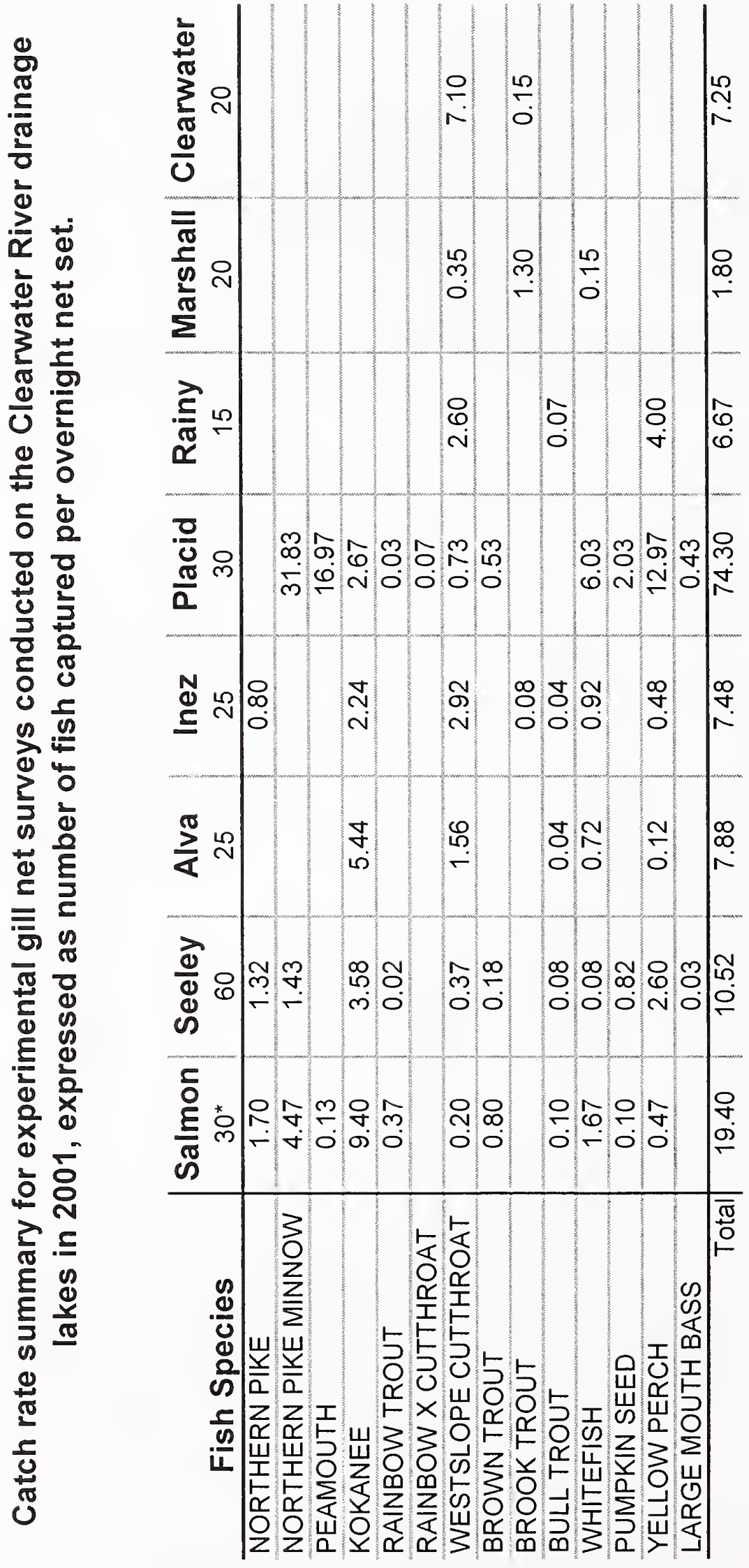

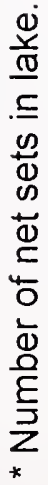

$\frac{\mathfrak{N}}{\frac{0}{0}}$ 


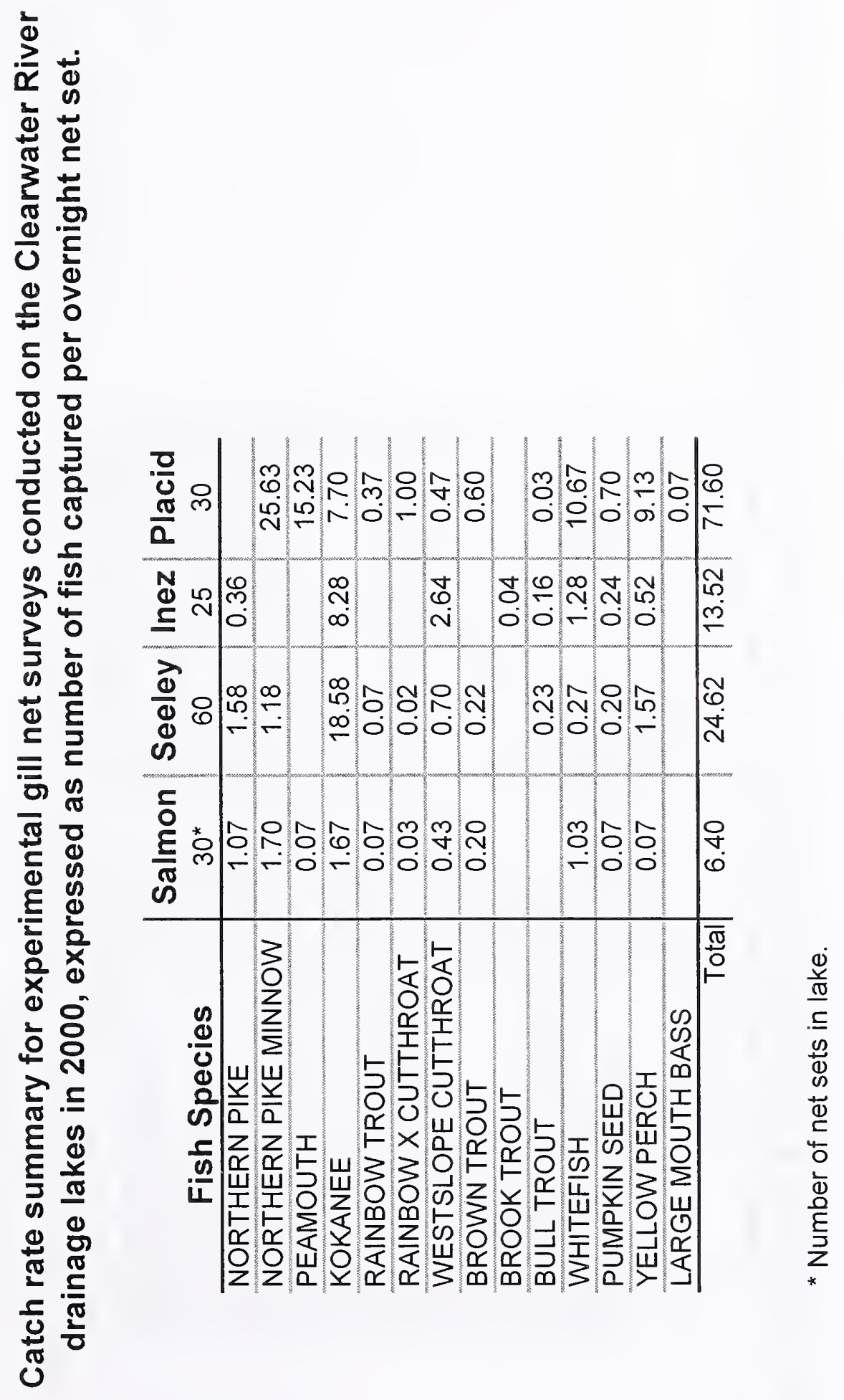

$\frac{\dot{\theta}}{\frac{1}{0}}$ 


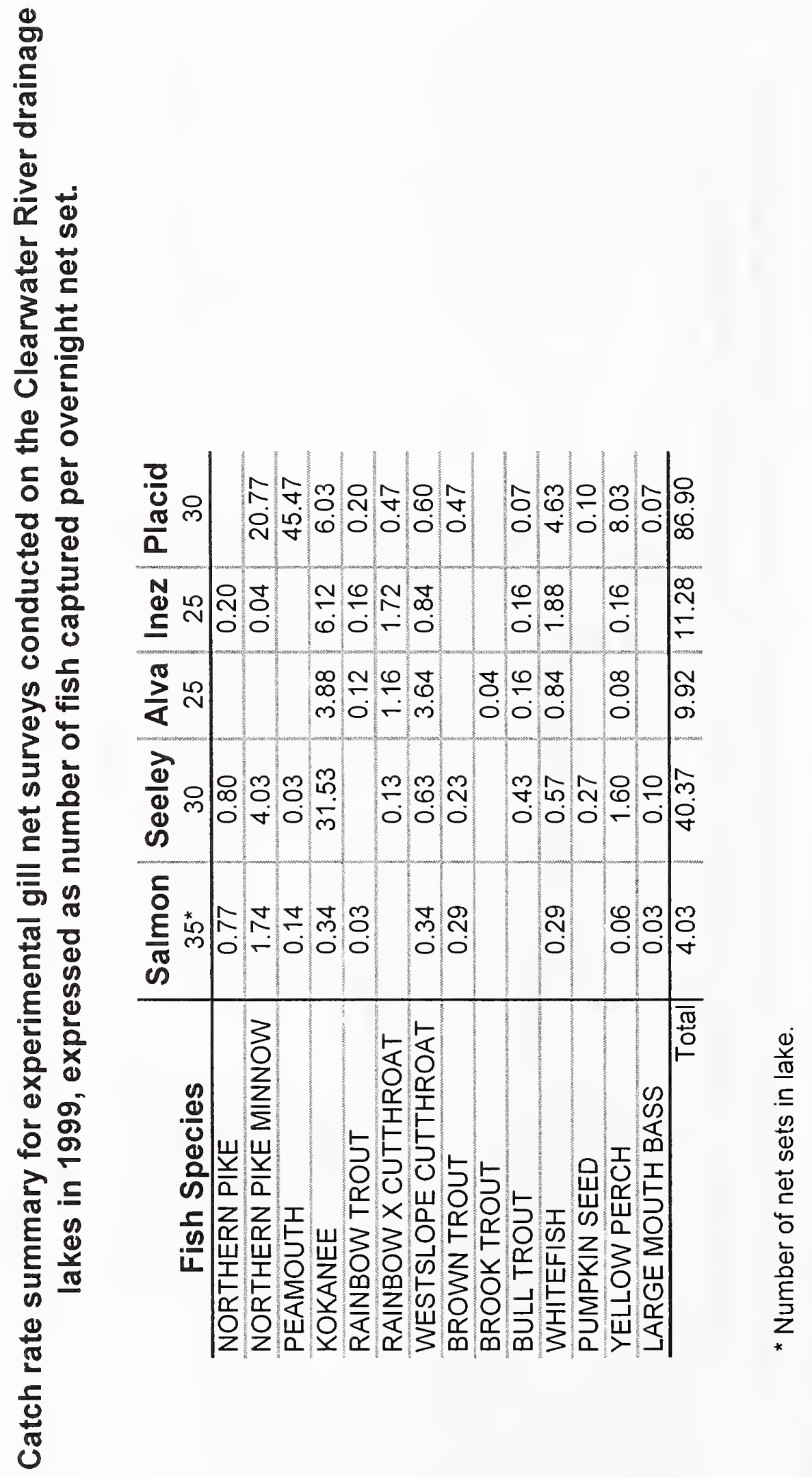

$\dot{0}$
$\frac{0}{0}$
$\frac{10}{6}$ 


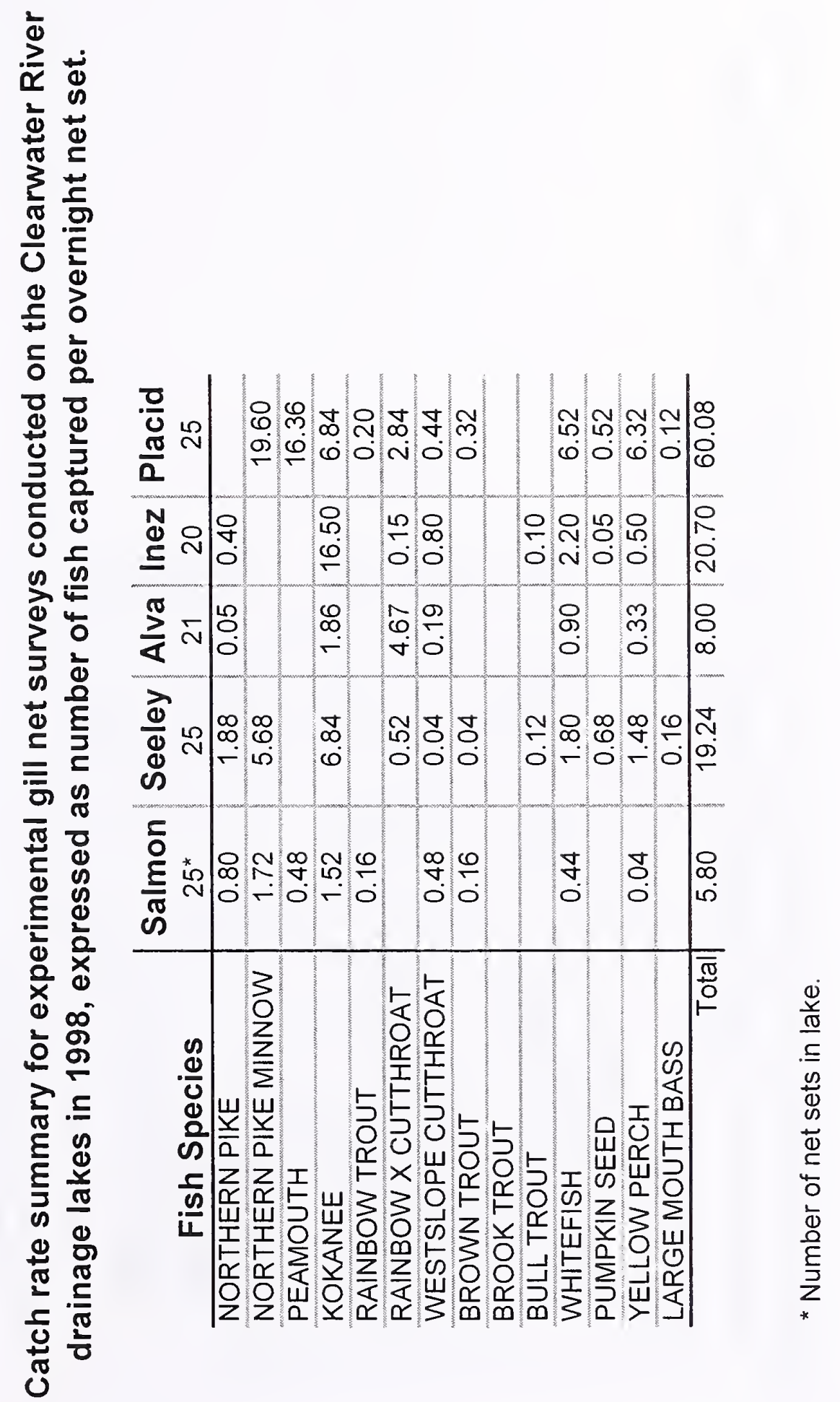




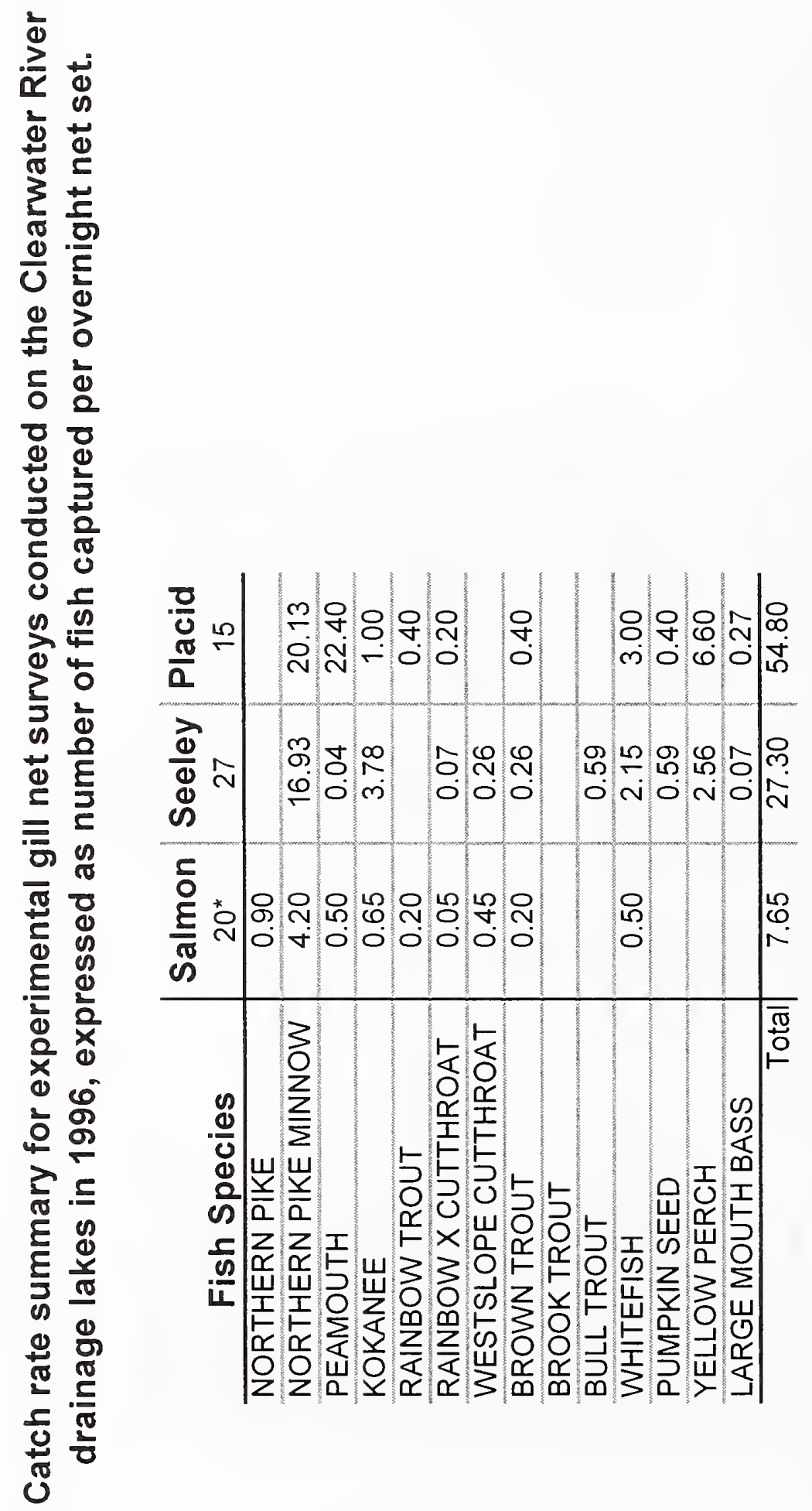

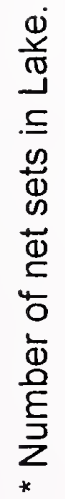

$\frac{\infty}{\frac{1}{0}}$ 


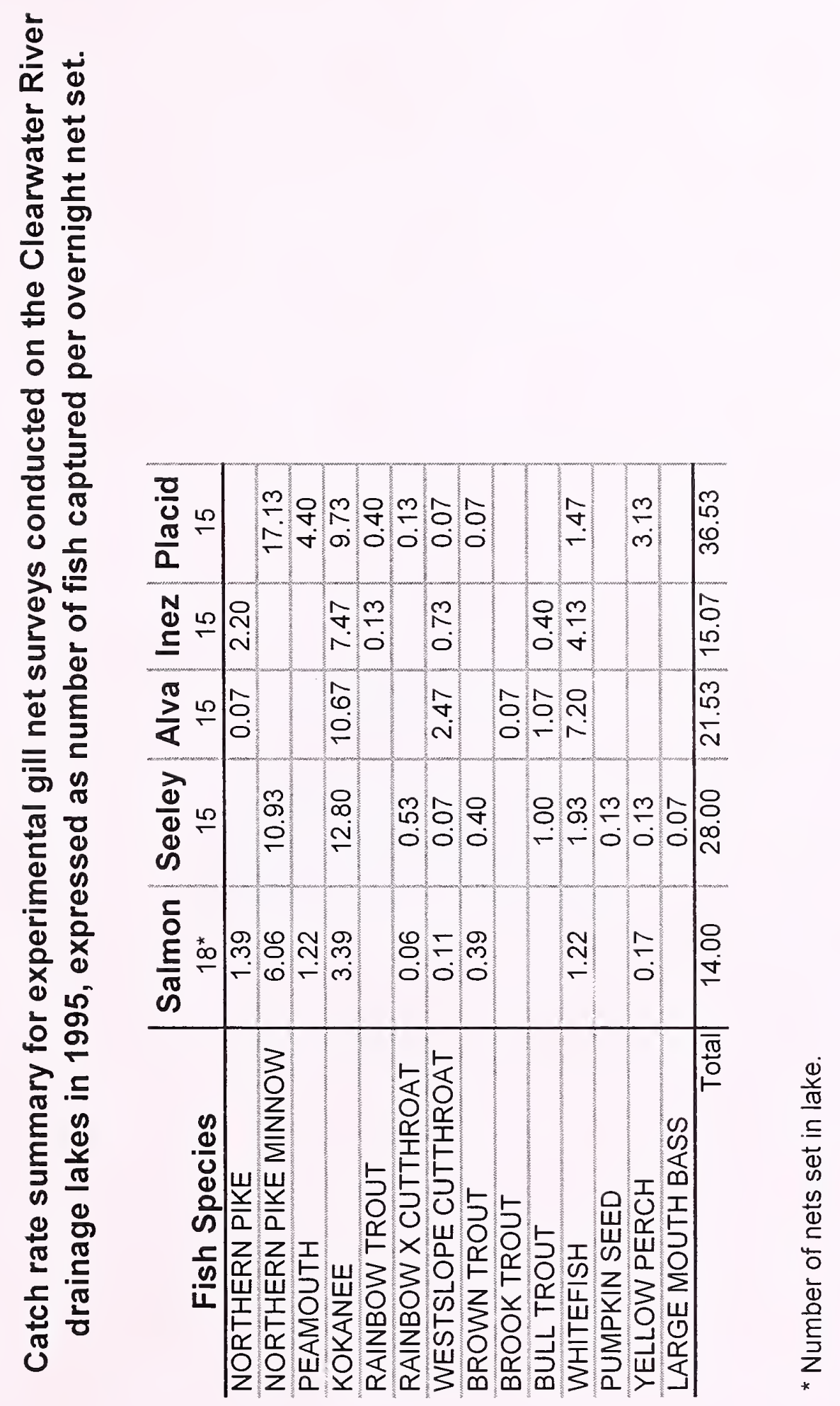





\section{APPENDIX 1}

Bathymetric Maps of

Eight Major Lakes in the

Clearwater River Drainage 



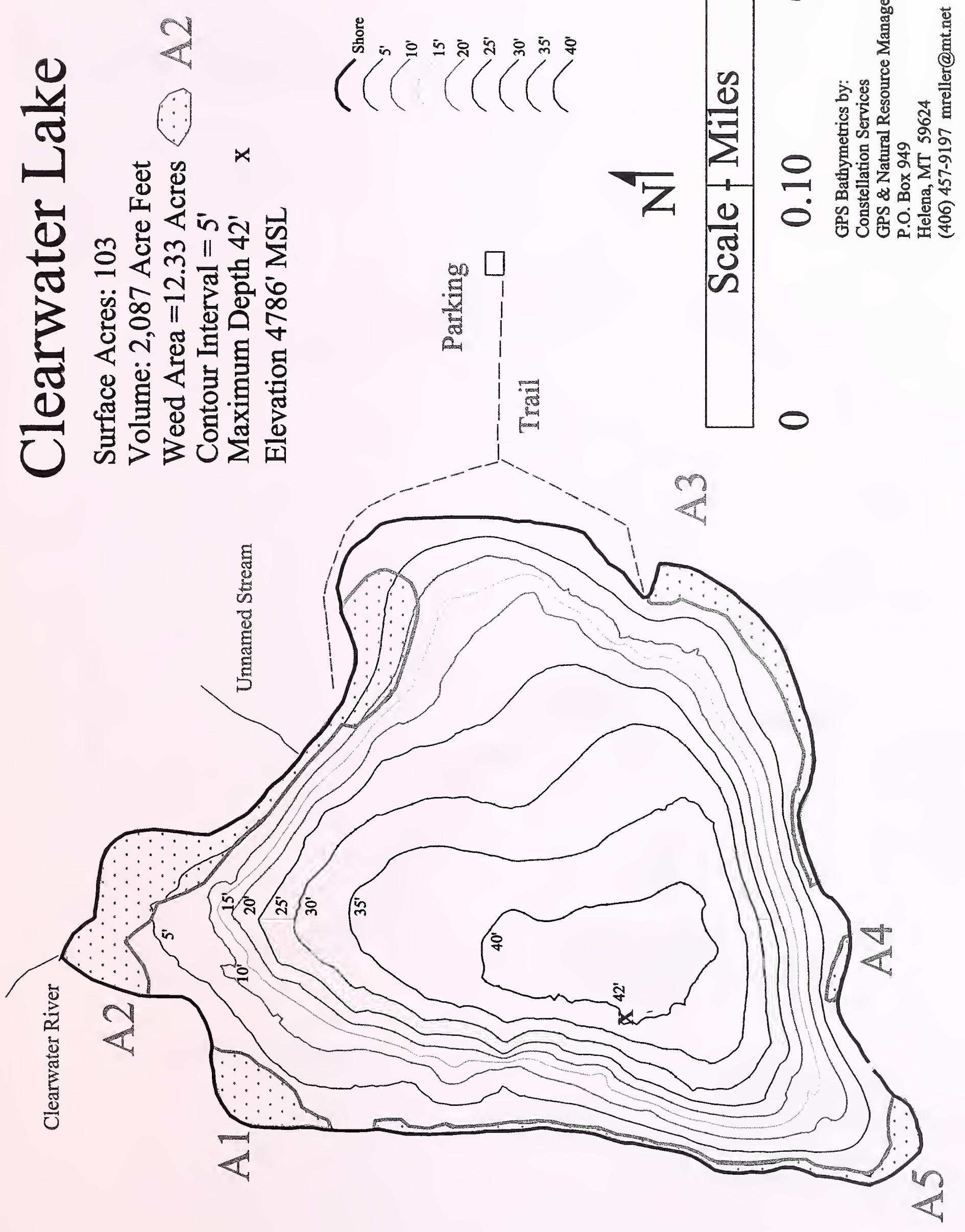





\section{Rainy Lake}

Surface Acres: 81

Volume: 1,420 Acre Feet

Weed Area $=8.97$ Acres $9 \mathrm{~A} 5$

Contour Interval $=5^{\prime}$

Maximum Depth 29.4' X

Elevation 4094' MSL

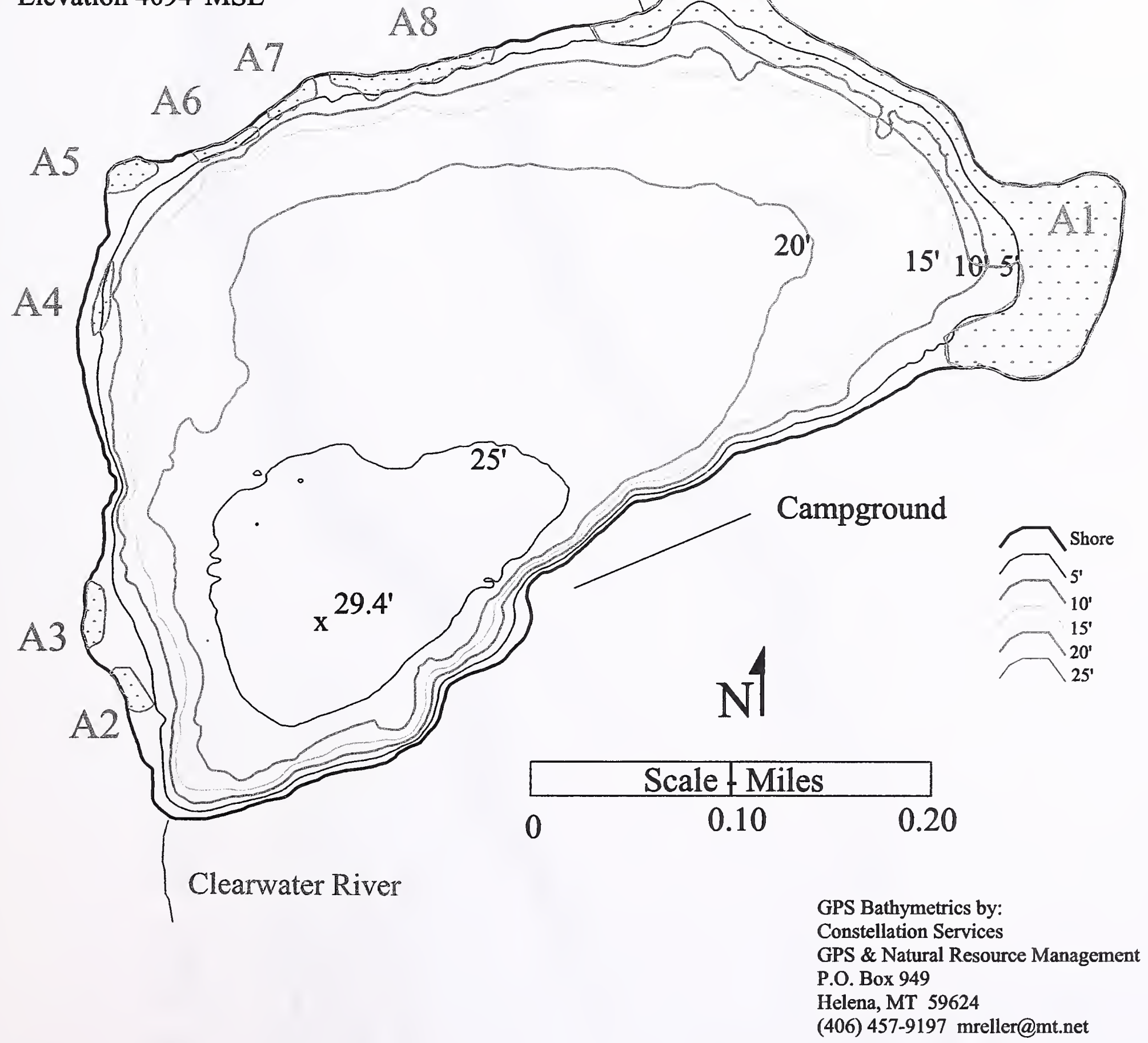





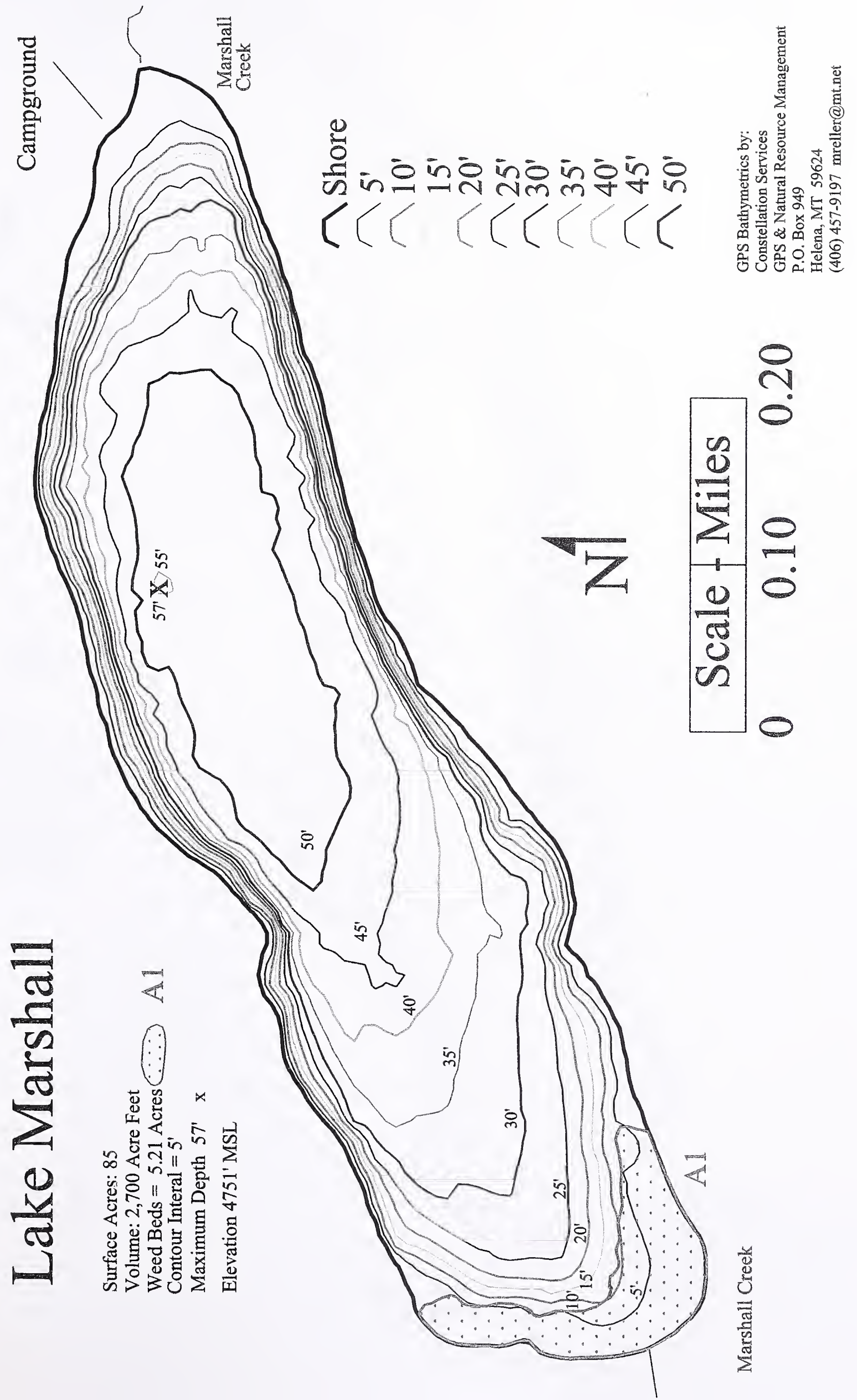





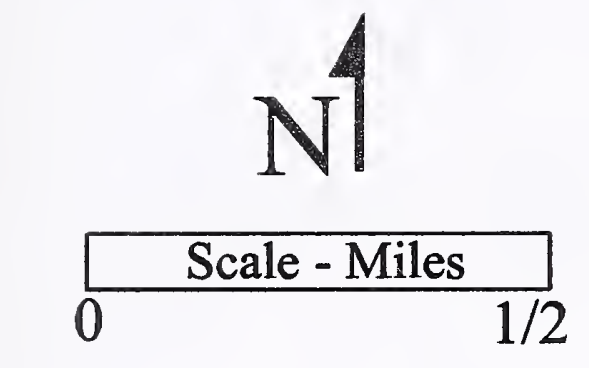

\section{Lake Alva}

Surface Acres: 314

Volume: 15,477 Acre Feet

Weed Beds $=8.45$ Acres $\mathrm{A}_{4}$

Contour Interval $=10^{\prime}$

Maximum Depth 90.1' $\quad \mathrm{x}$

Elevation 4074' MSL

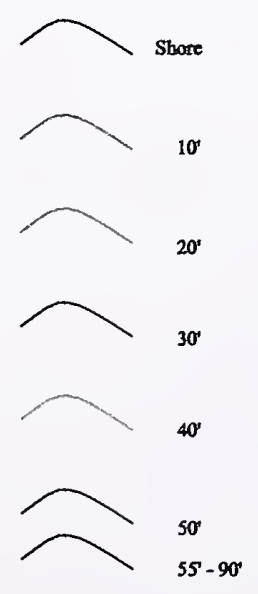

메 세

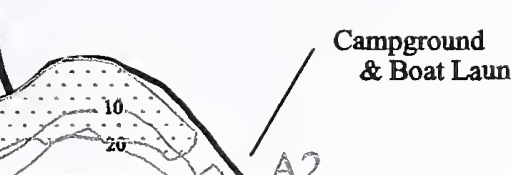

/ Richmond Creek 


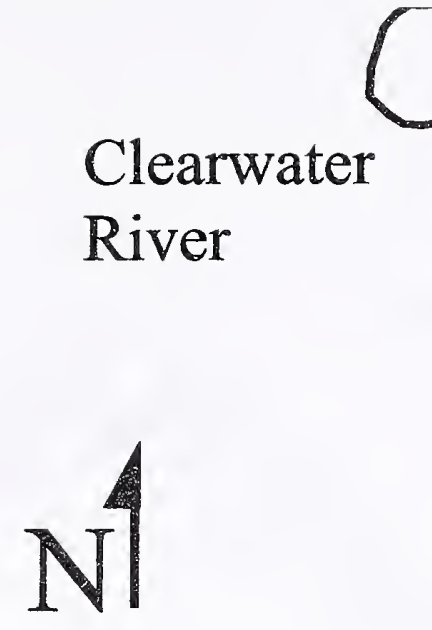

\section{Scale - Miles}

\section{$0 \quad 1 / 2$ \\ Lake Inez}

Surface Acres $=298$

Volume $=11,577$ Acre feet

Weed Area $=17.1$ Acres

Countour Interval $=10^{\prime}$

Maximum Depth 74' $\mathrm{x}$

Elevation 4061' MSL

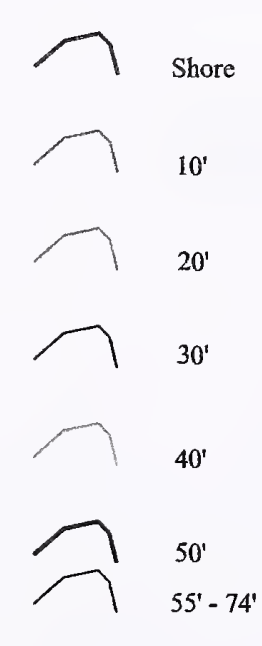

$\mathrm{x}$

Elevation 4061 MSL

Clearwater River

2 



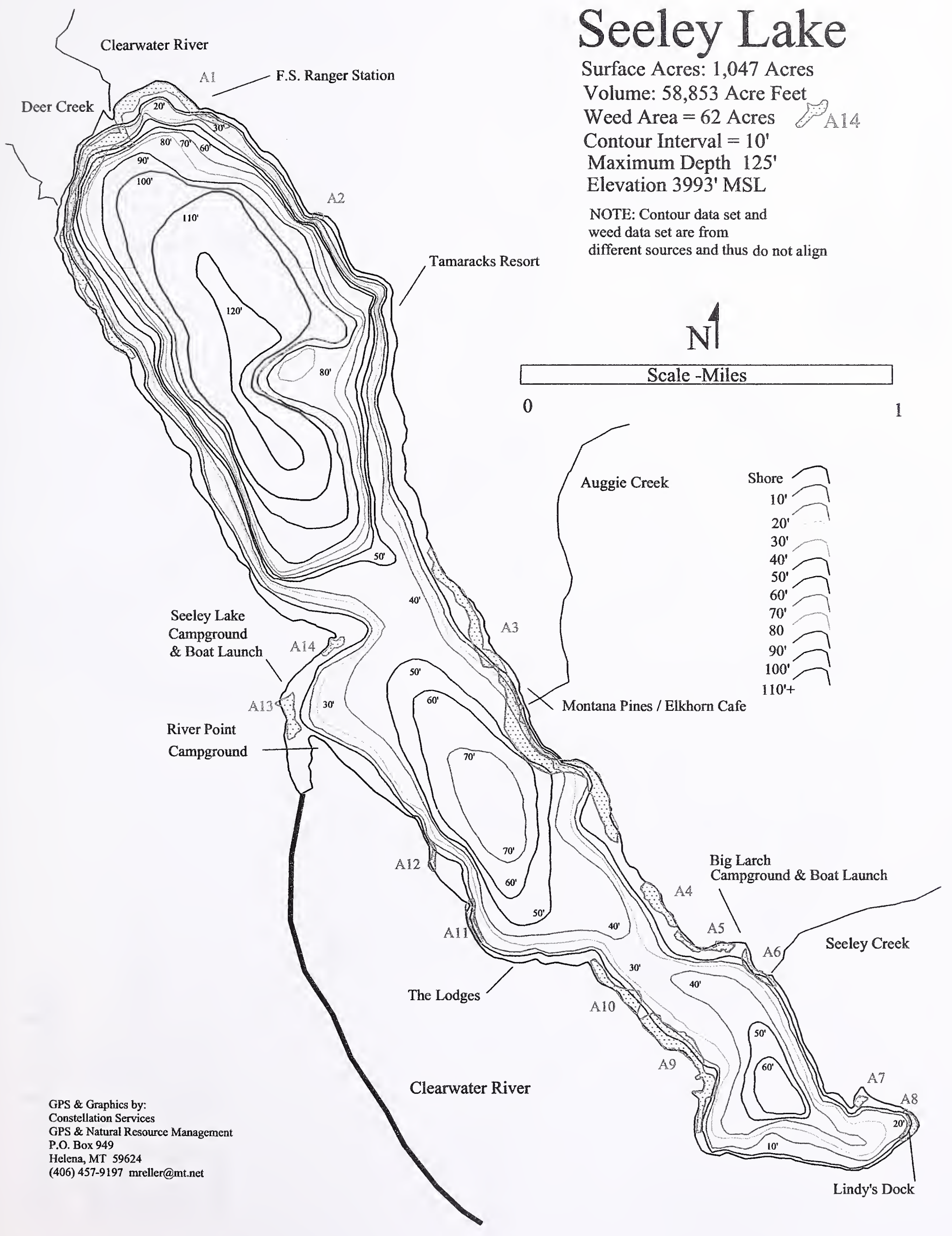





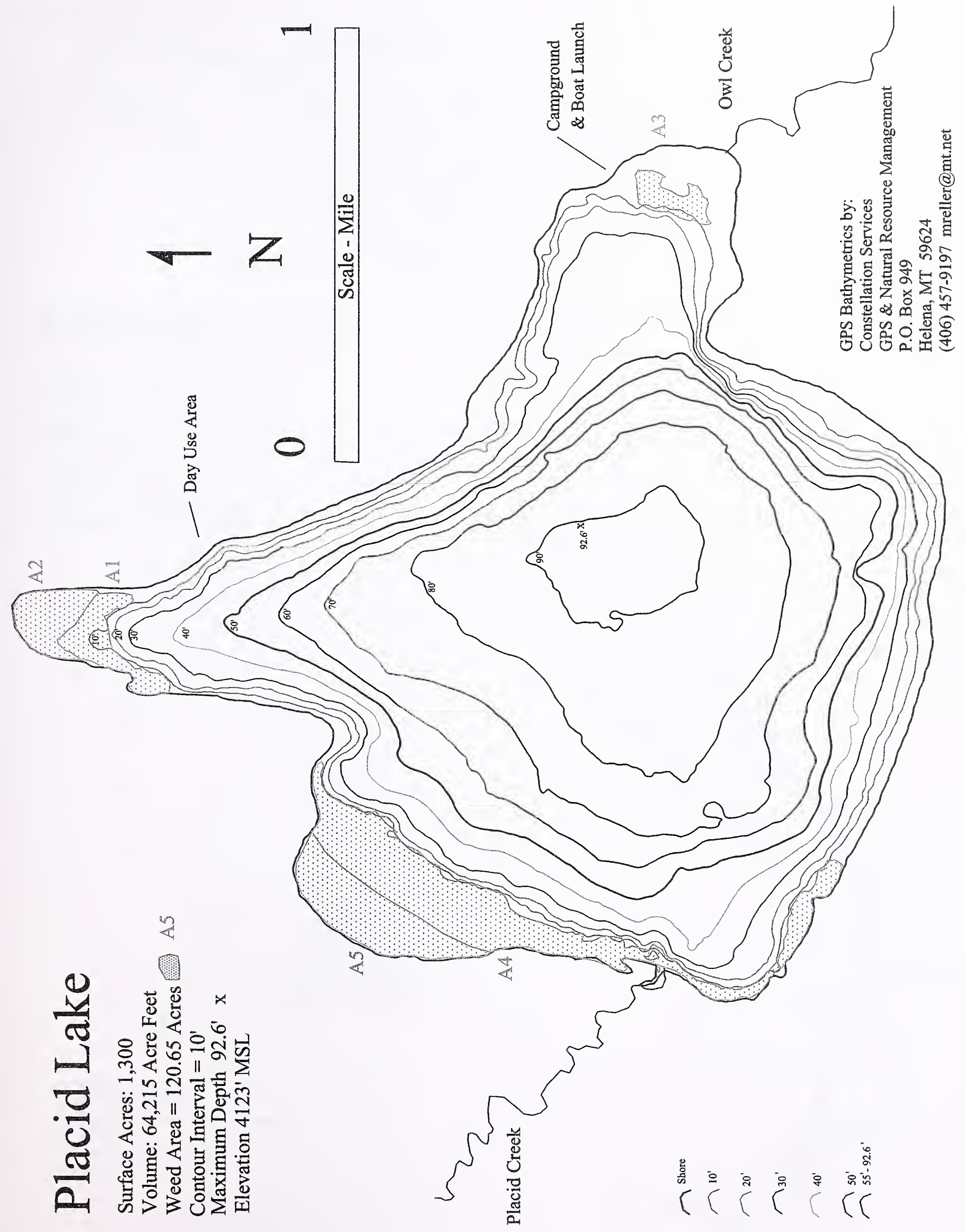






\section{APPENDIX 2}

Tabular Summaries of Gill Net Surveys

Conducted in

Clearwater River Drainage Lakes

Since 1995 


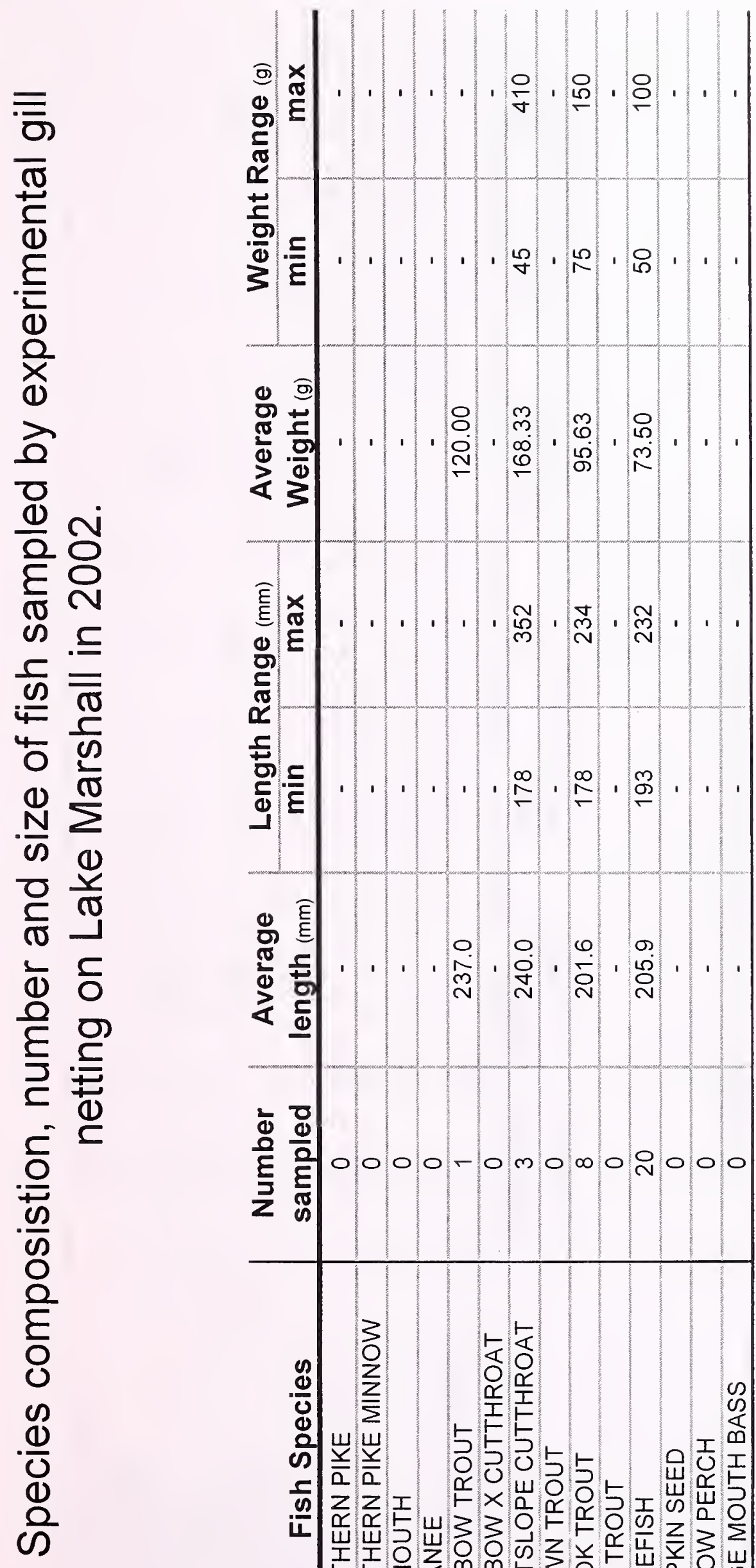

它

담

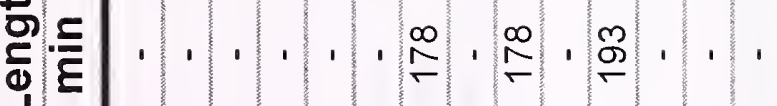

$\frac{1}{0}$
$\frac{0}{0}$
$\frac{x}{0}$
$\frac{1}{0}$
0
$\frac{0}{0}$

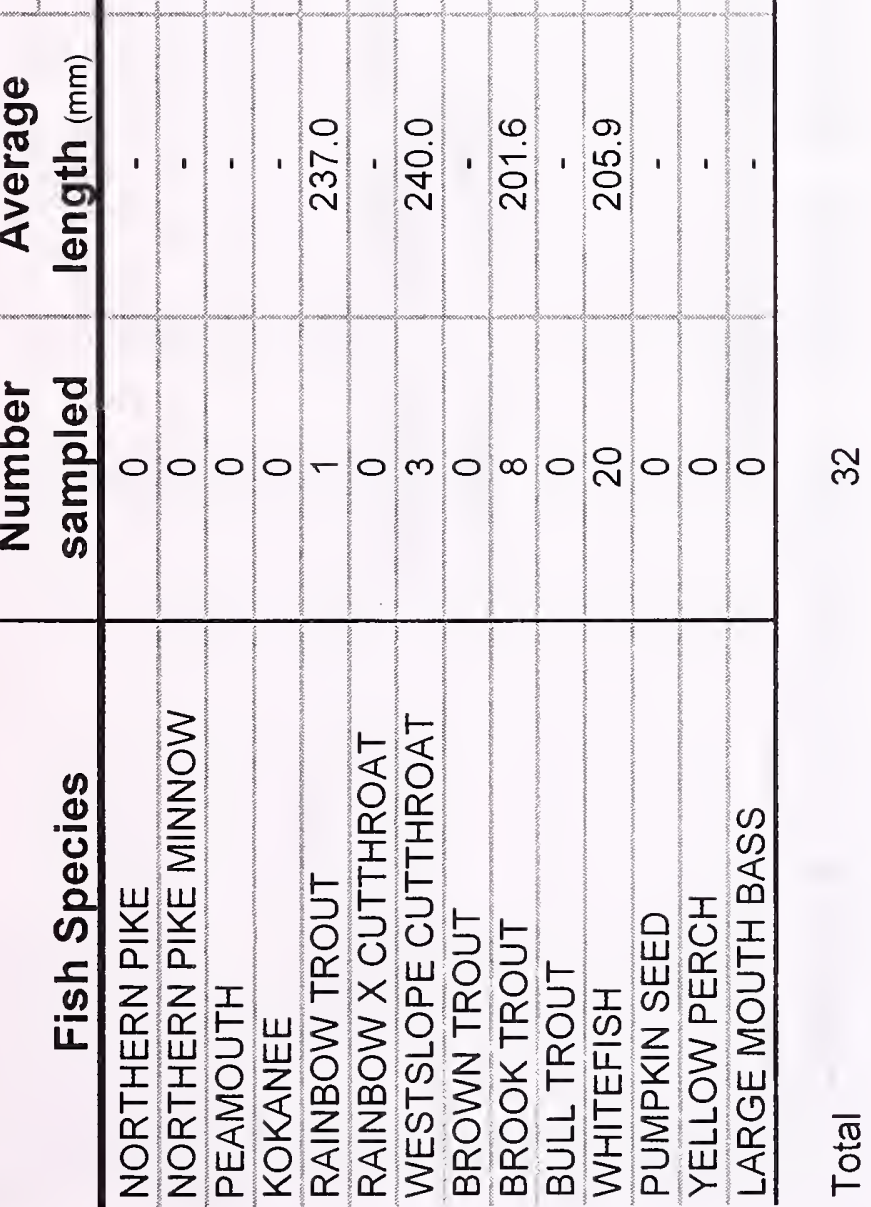




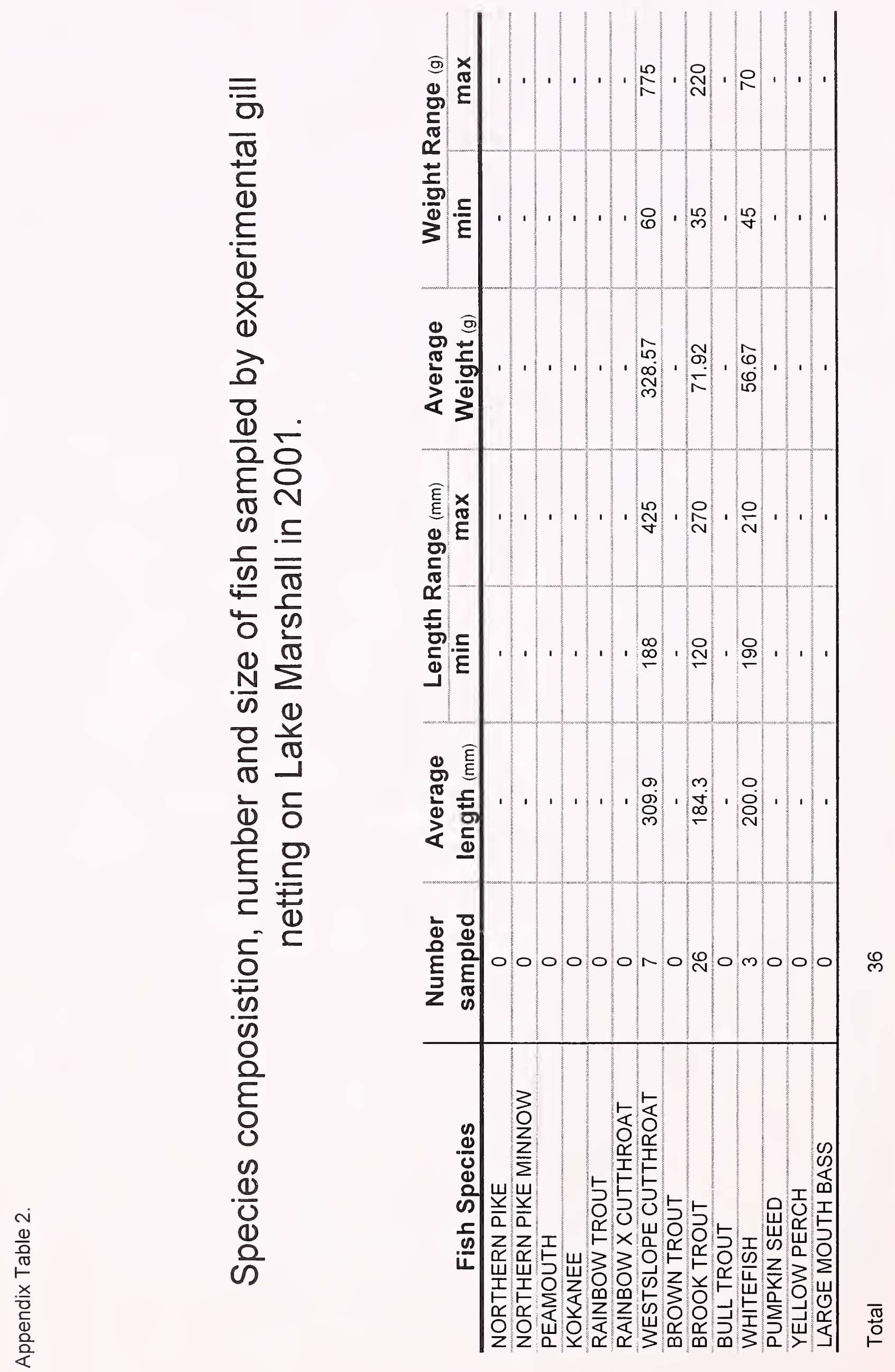




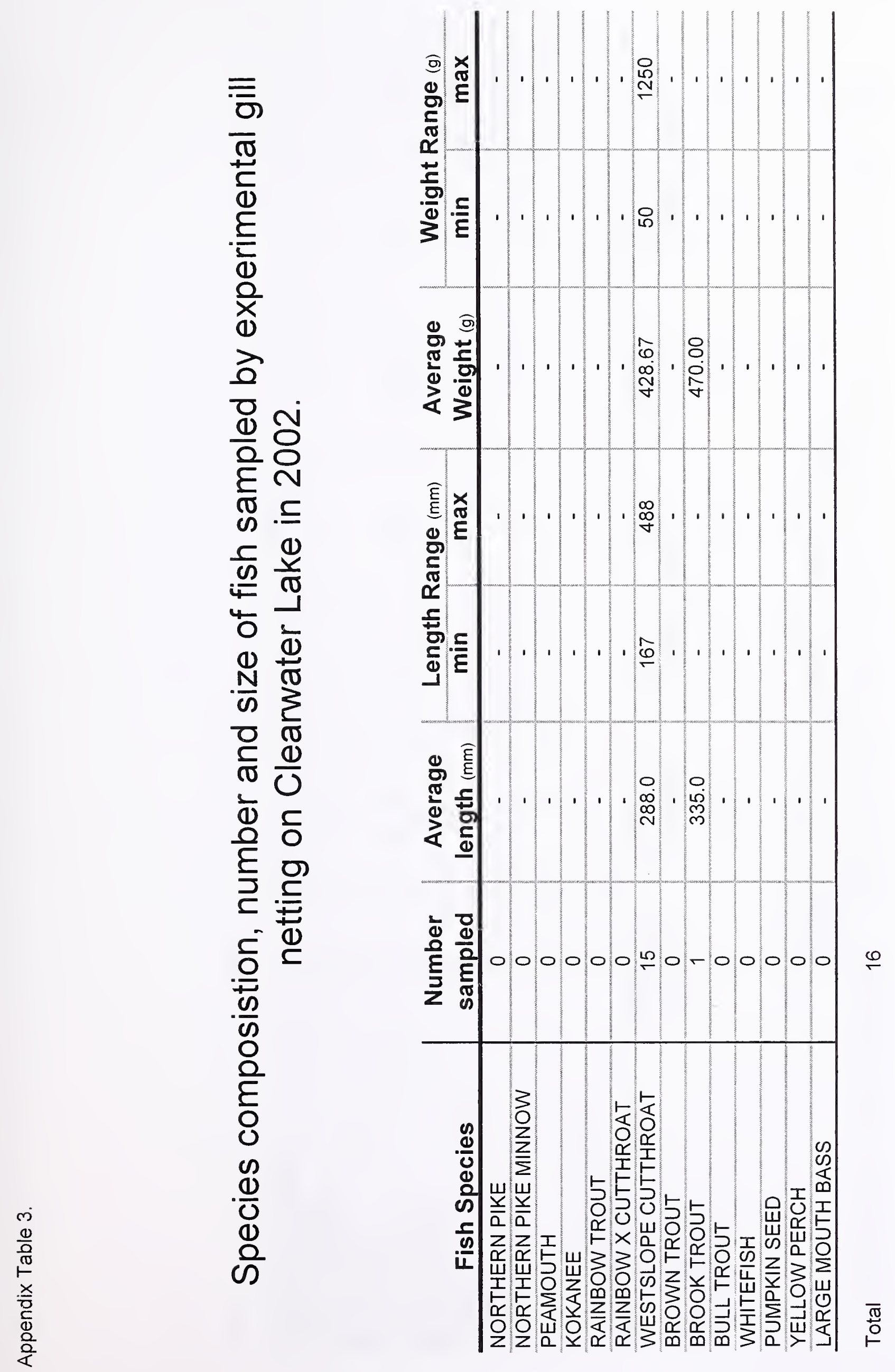




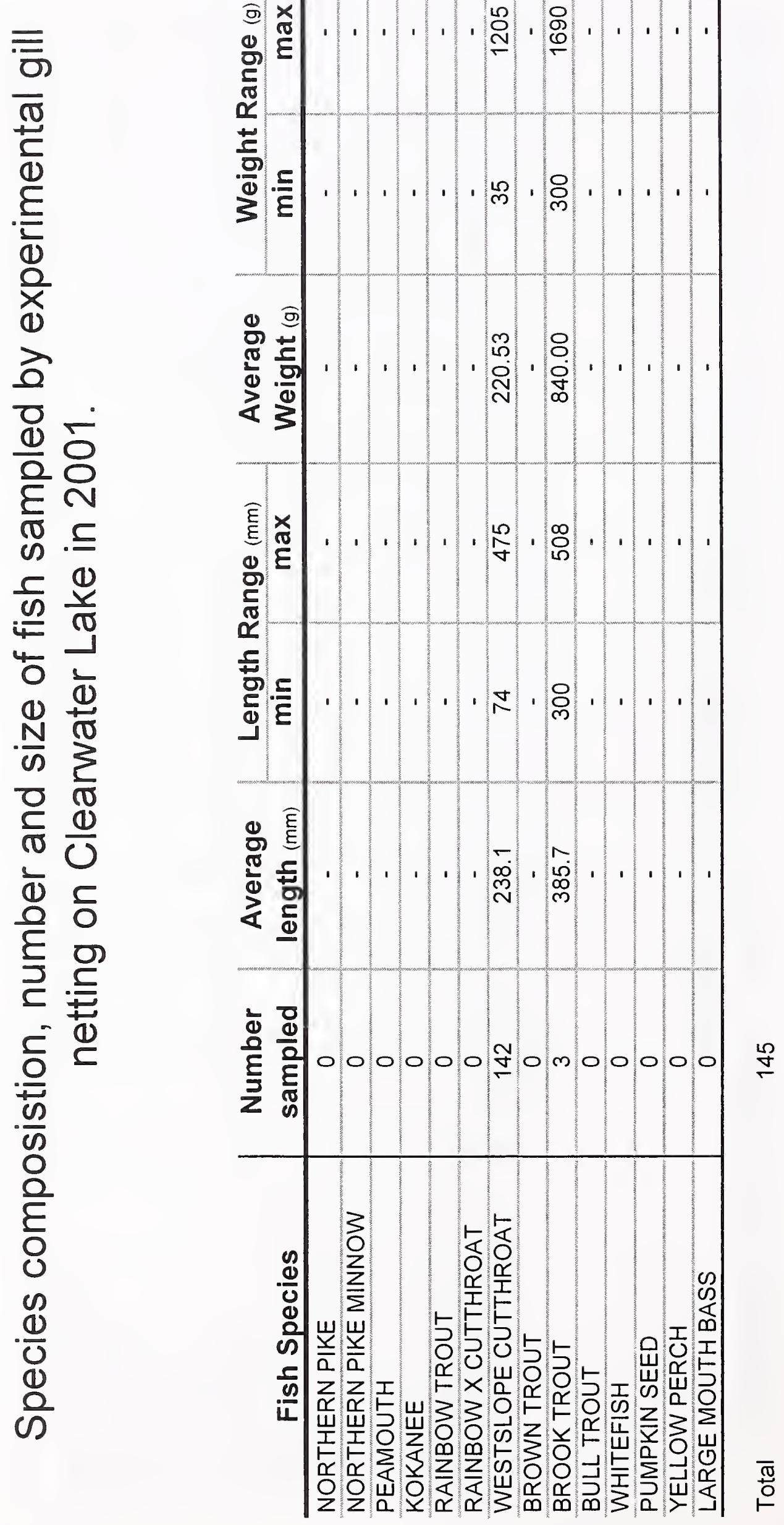




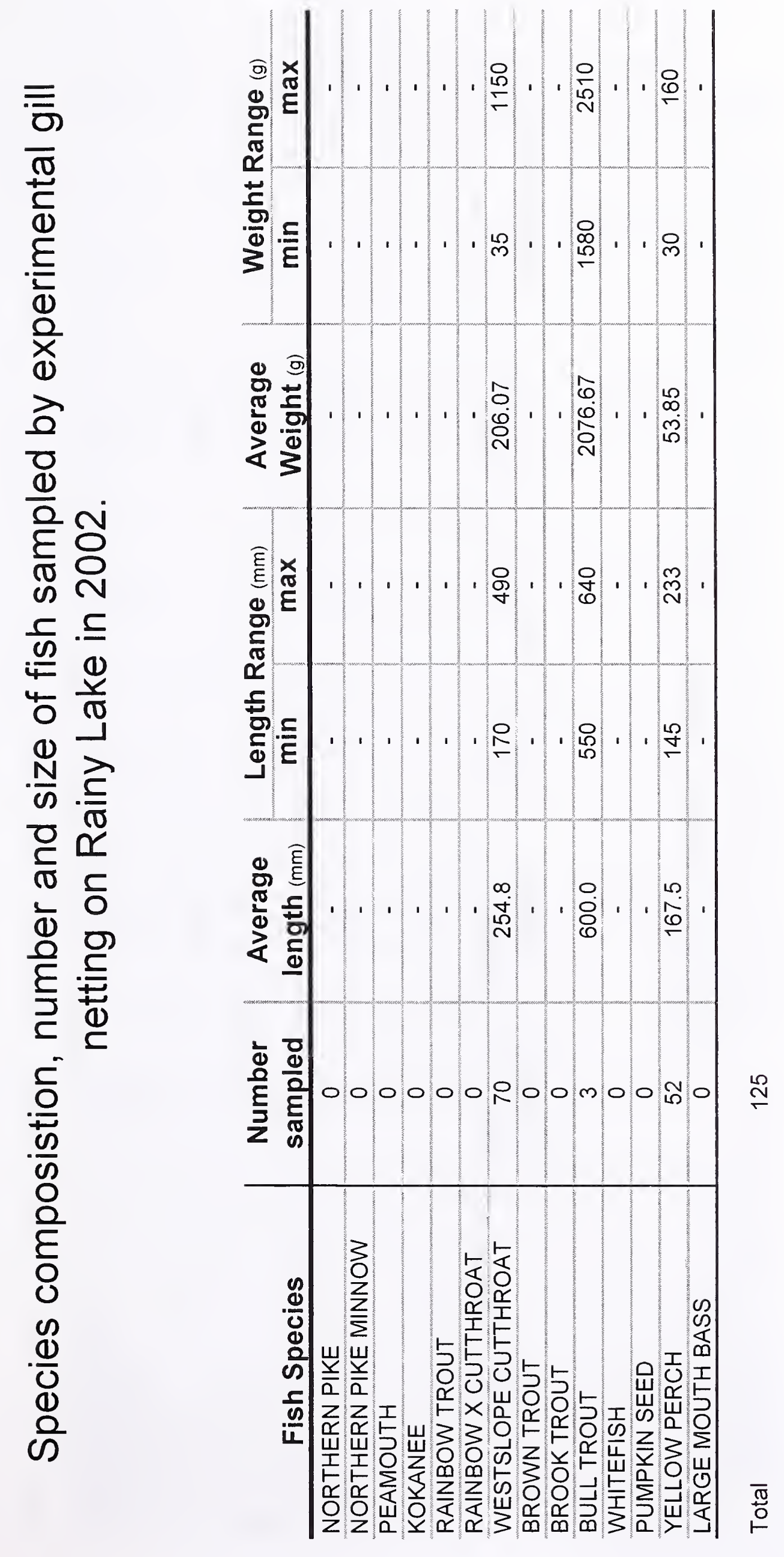




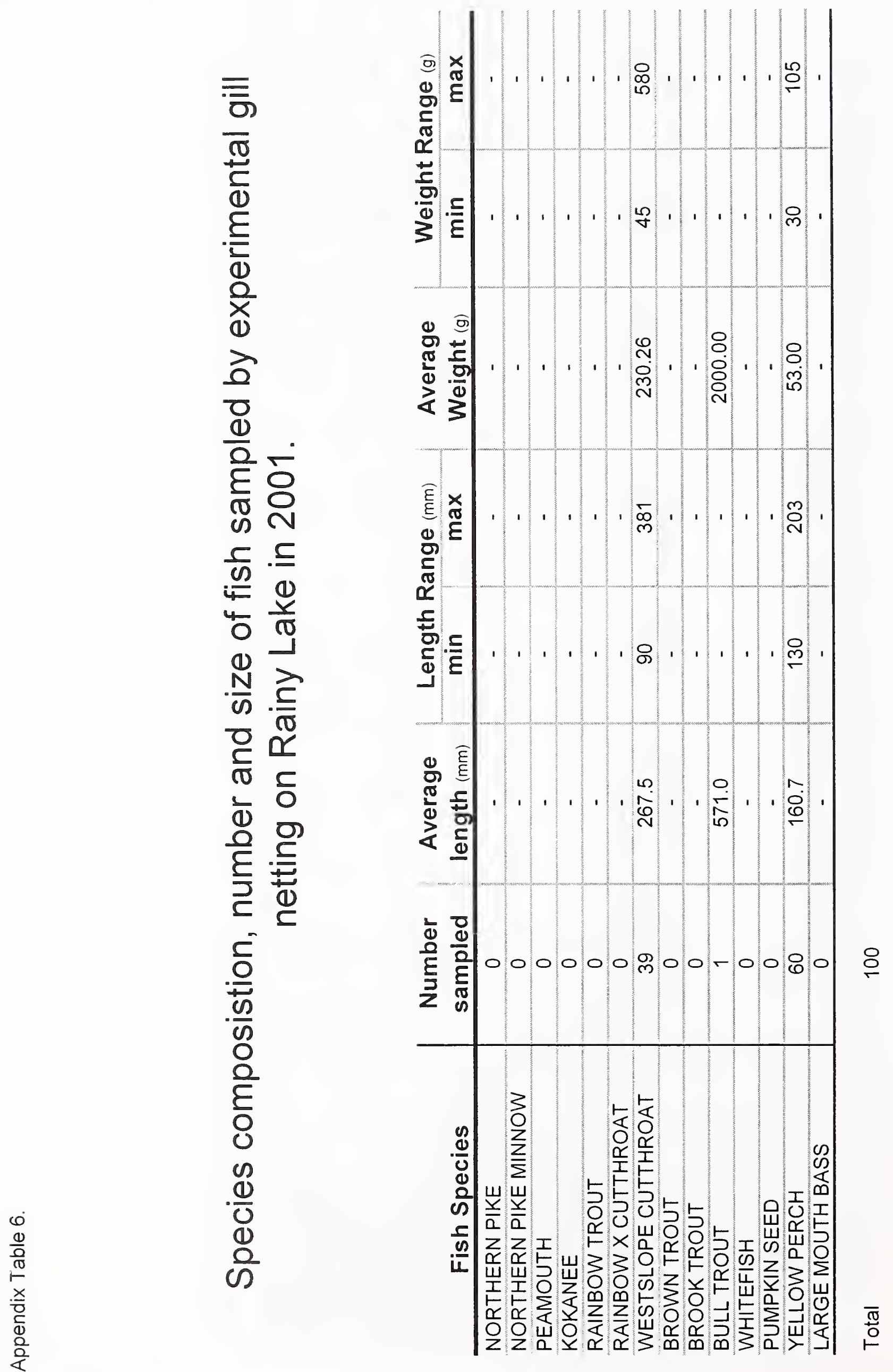




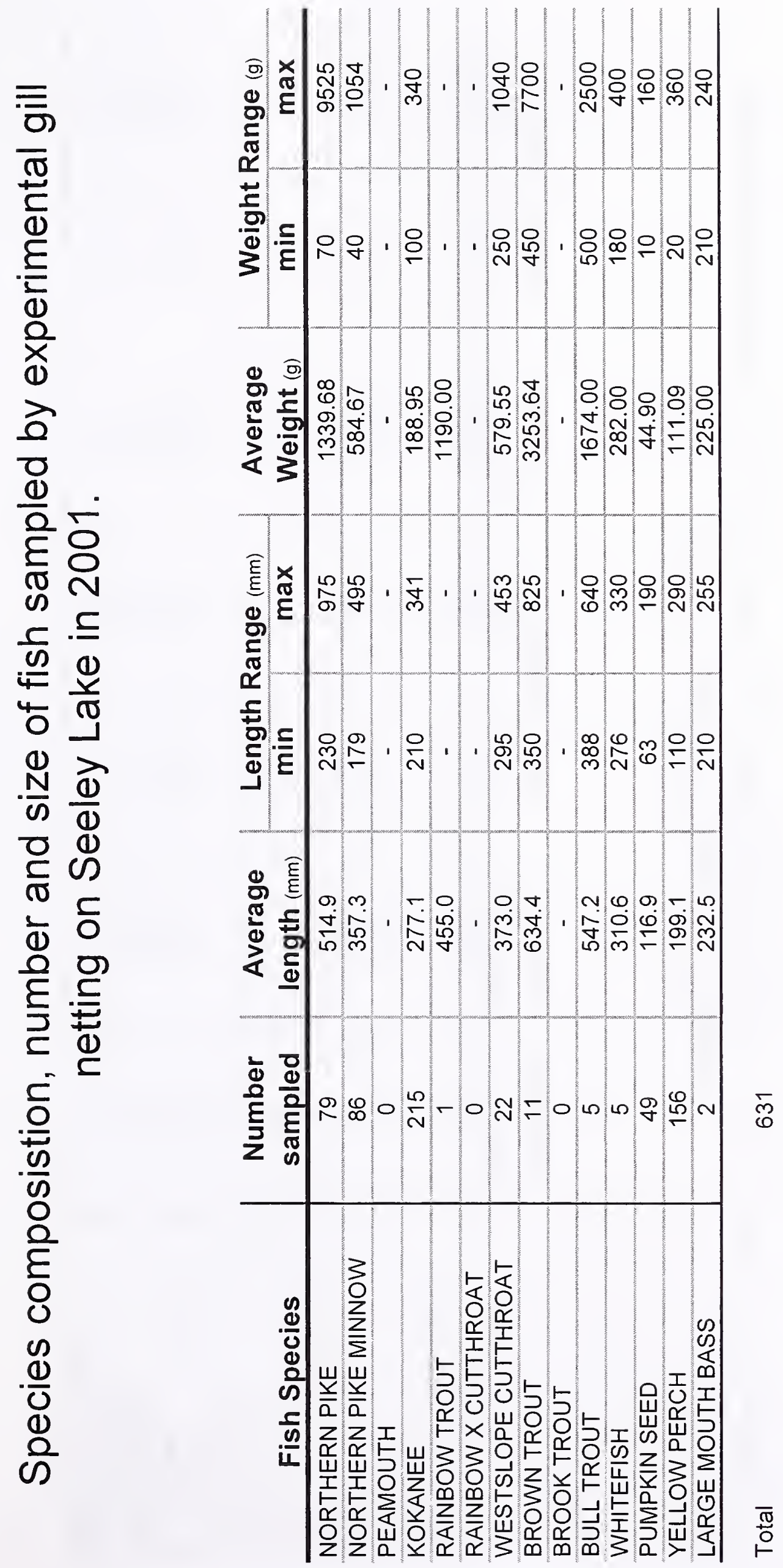




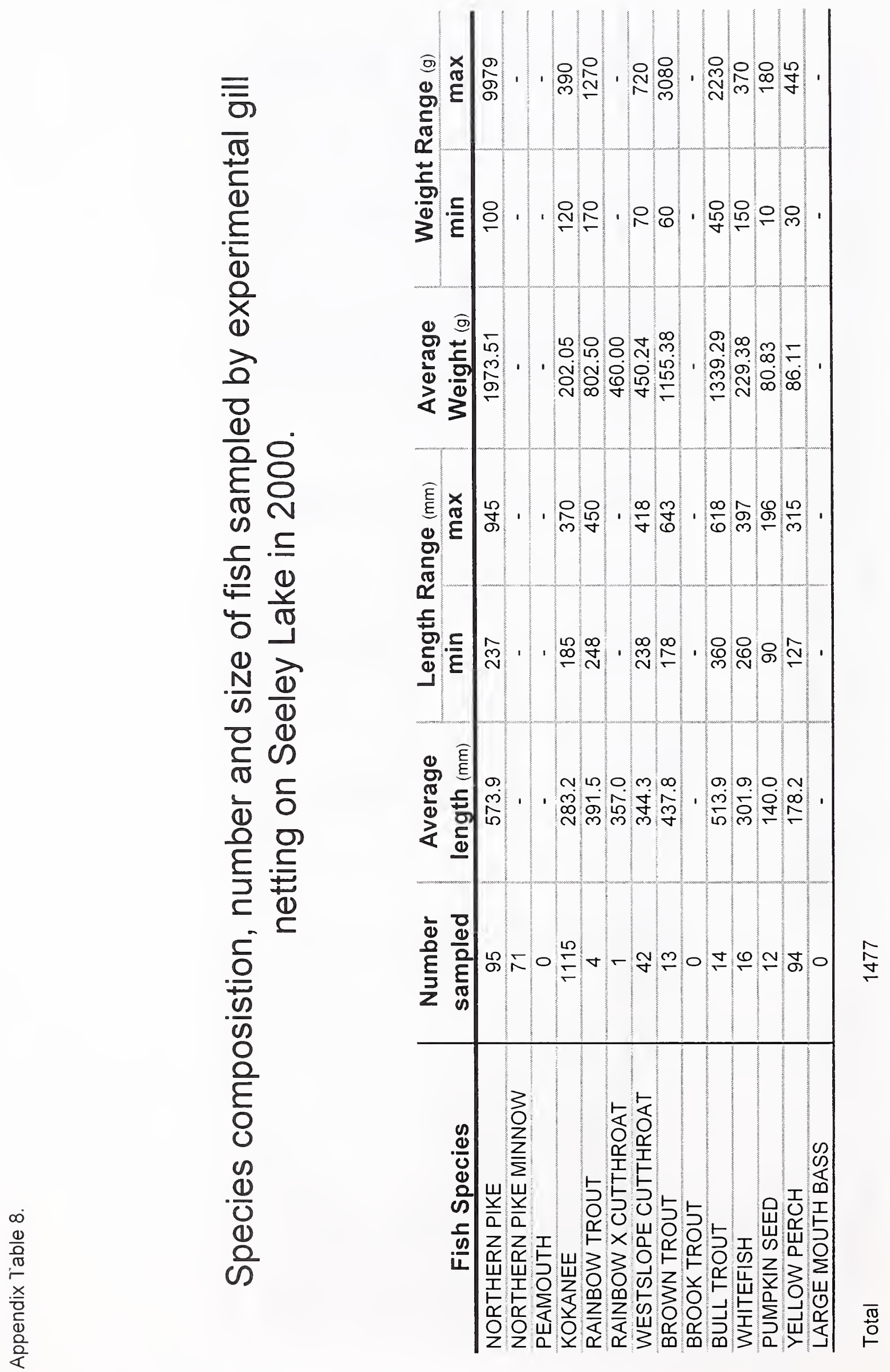




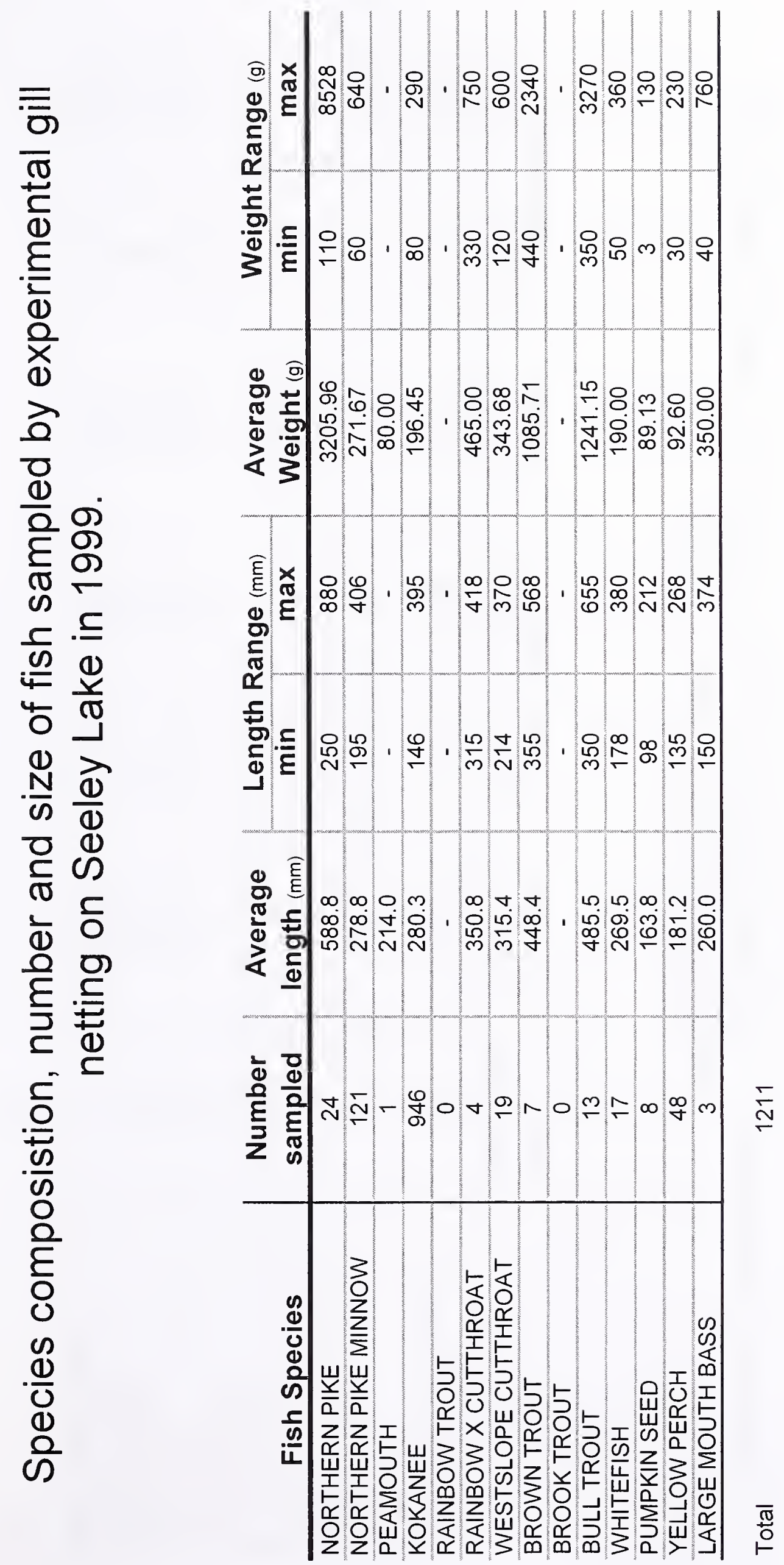




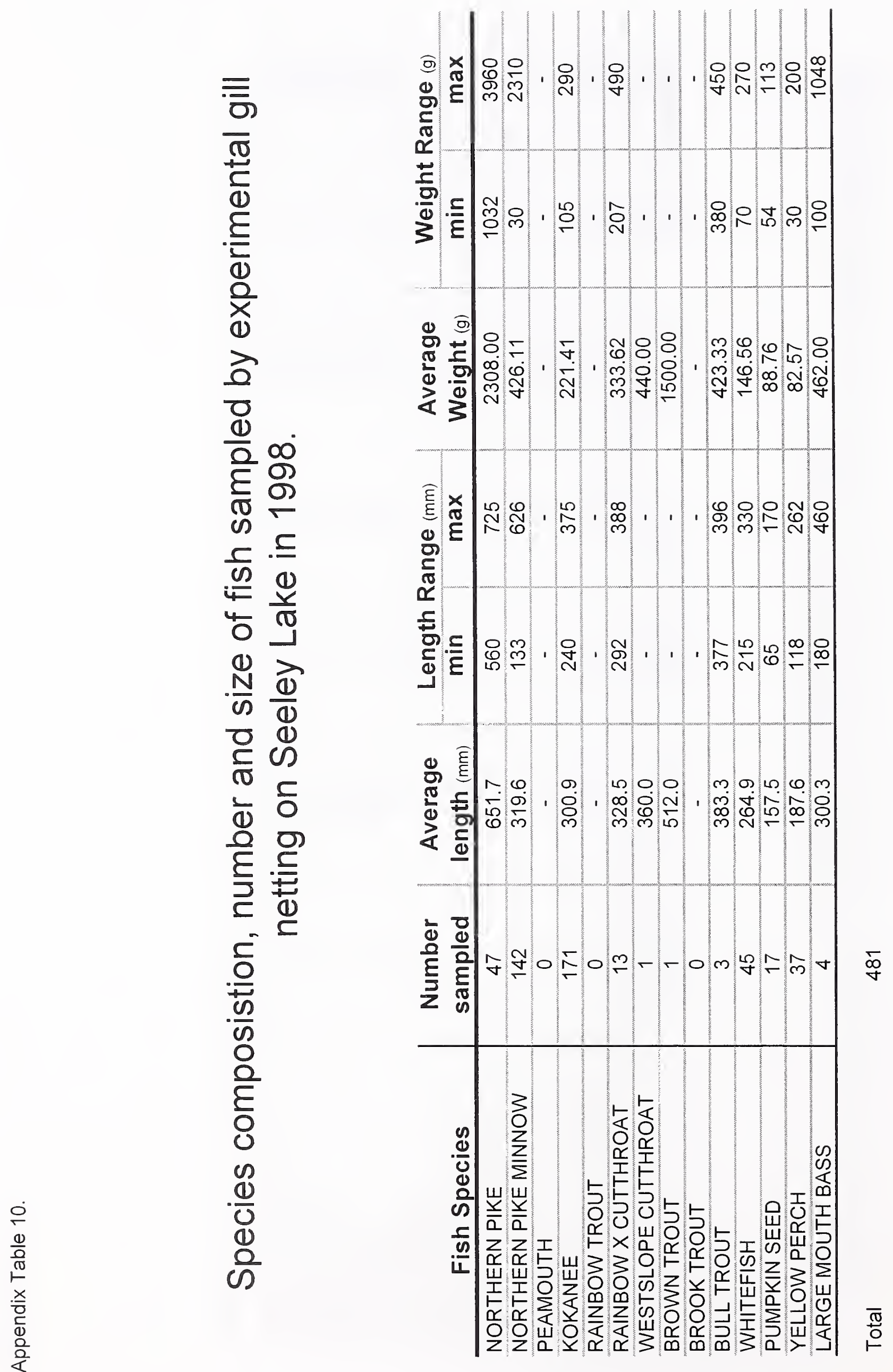



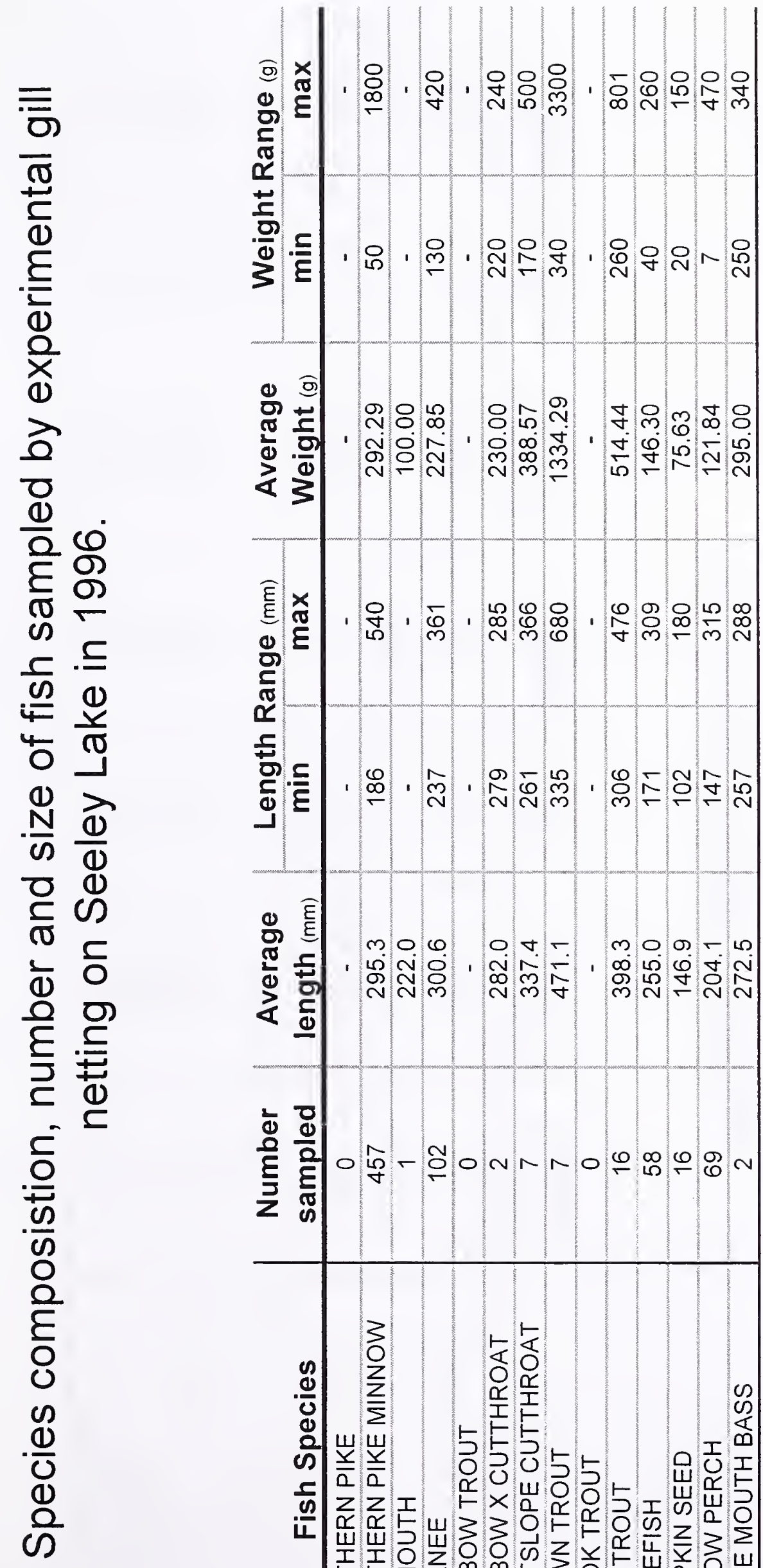

$\frac{\sigma}{\sigma}$
$\frac{0}{0}$
$\frac{0}{\circ}$
$\frac{x}{0}$
$\frac{1}{0}$
$\frac{0}{0}$

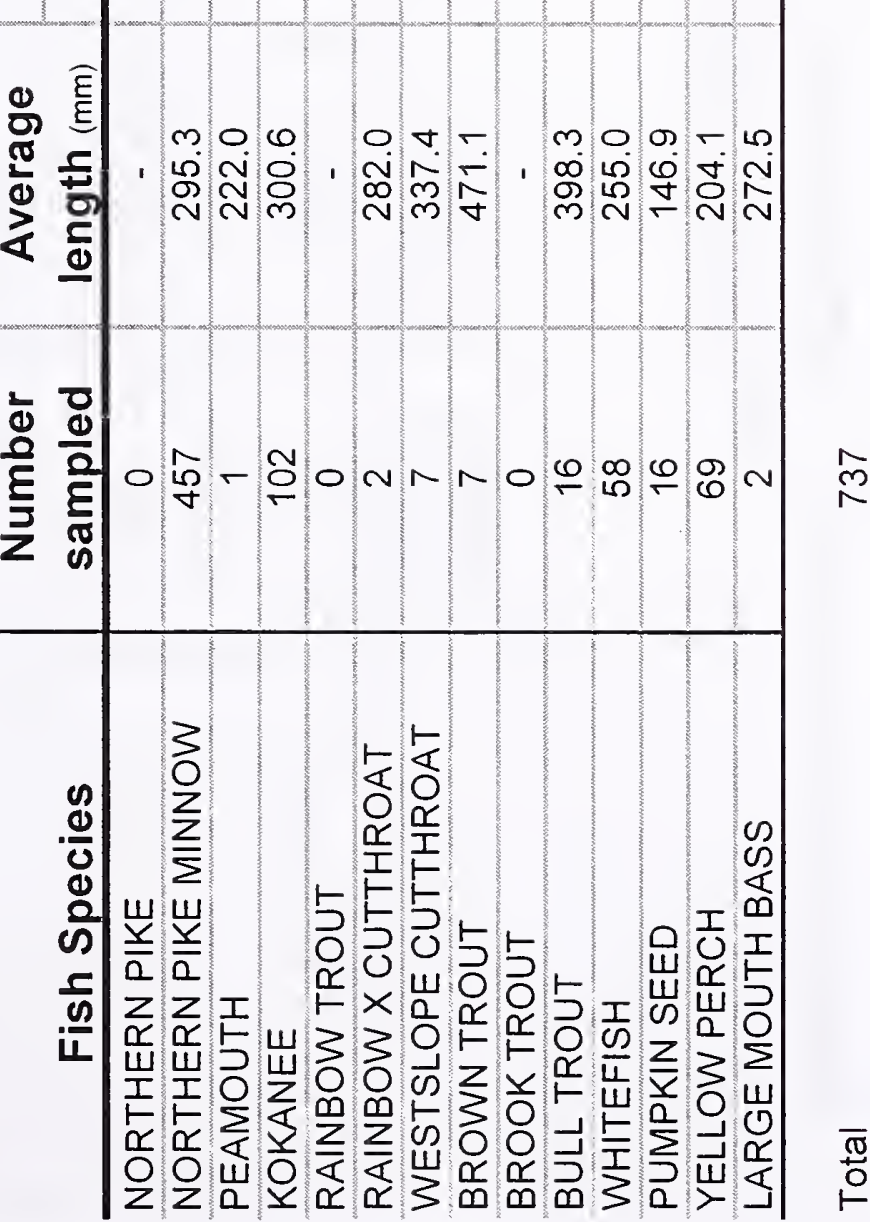




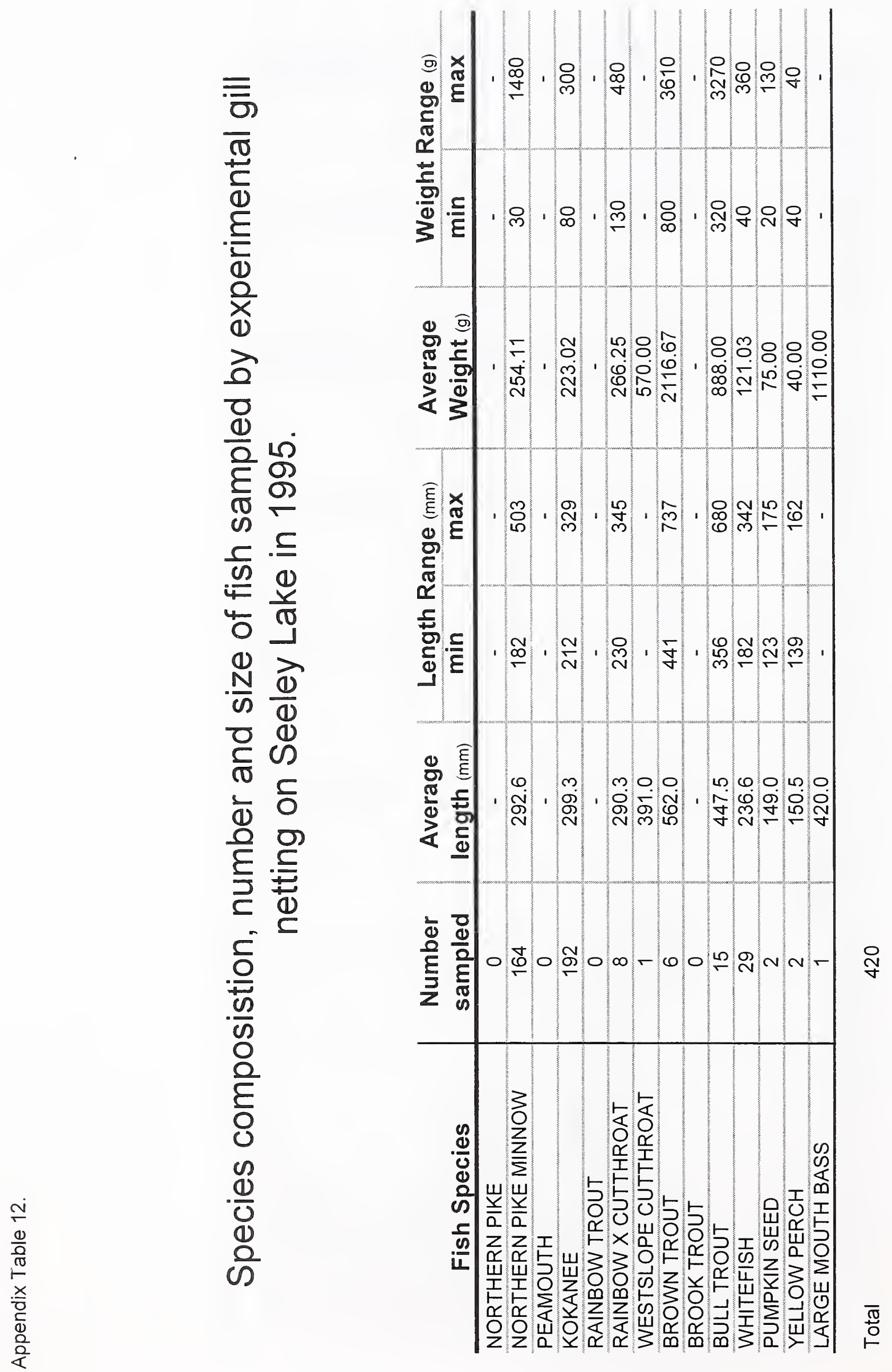



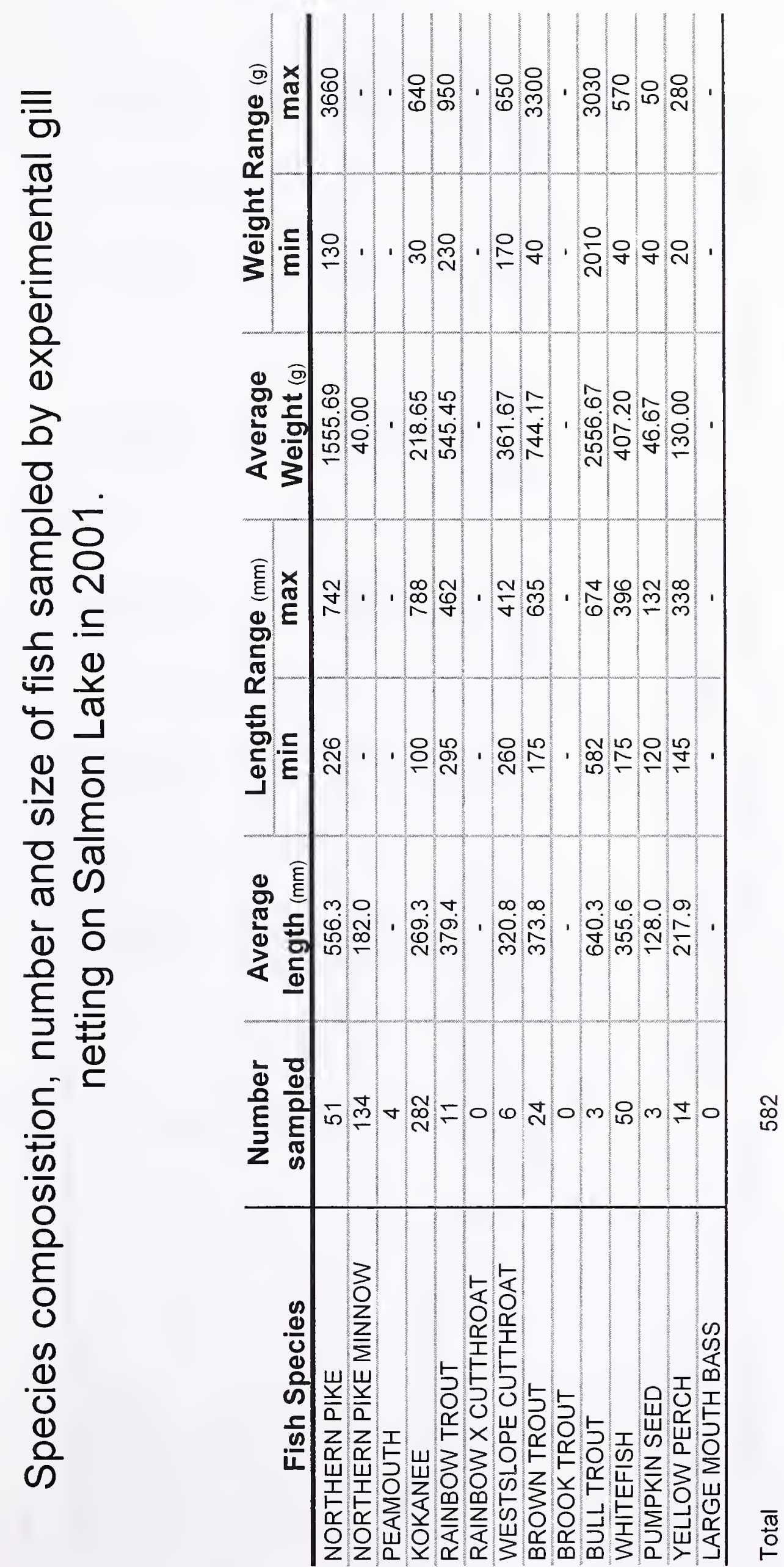


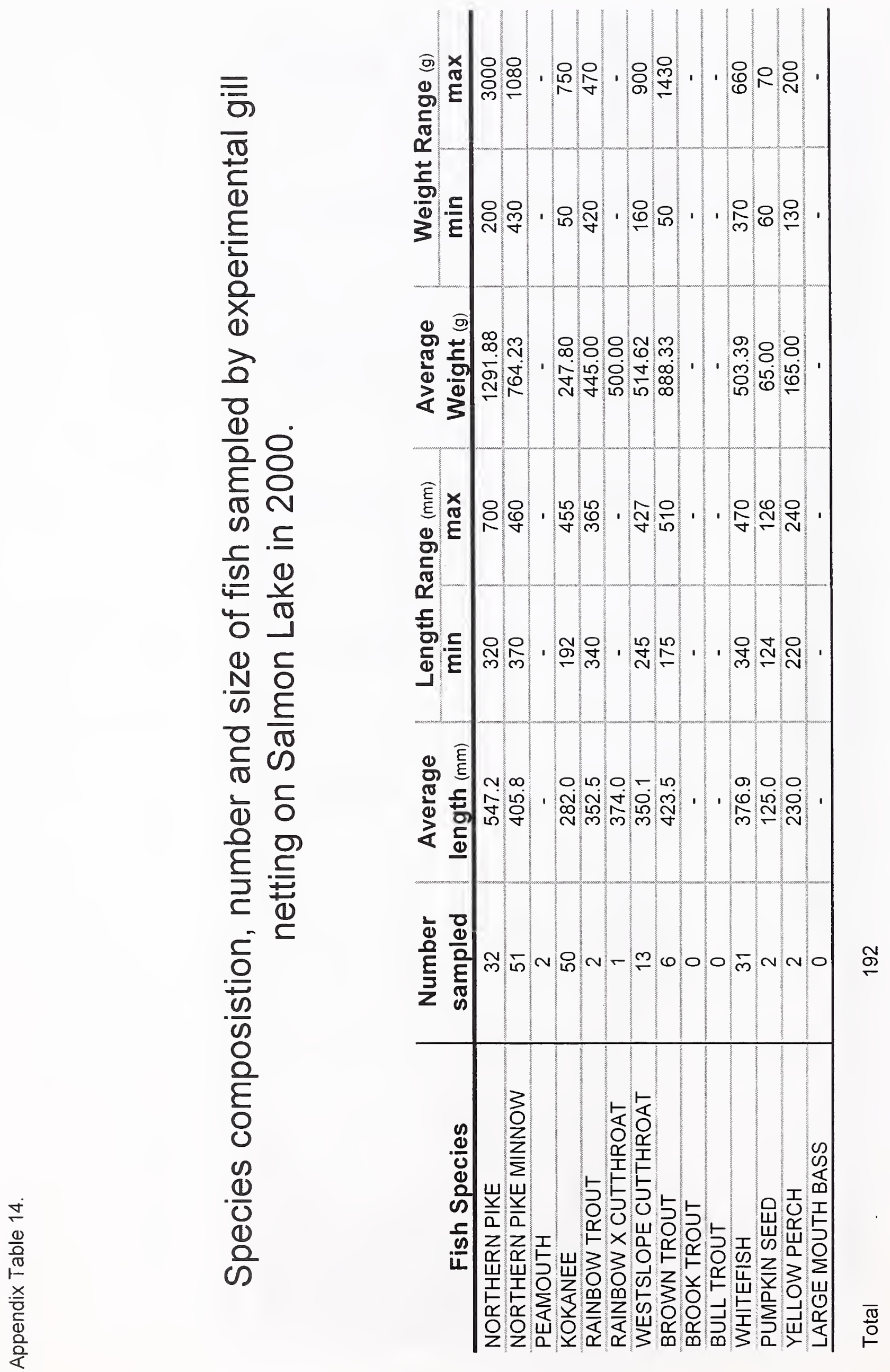



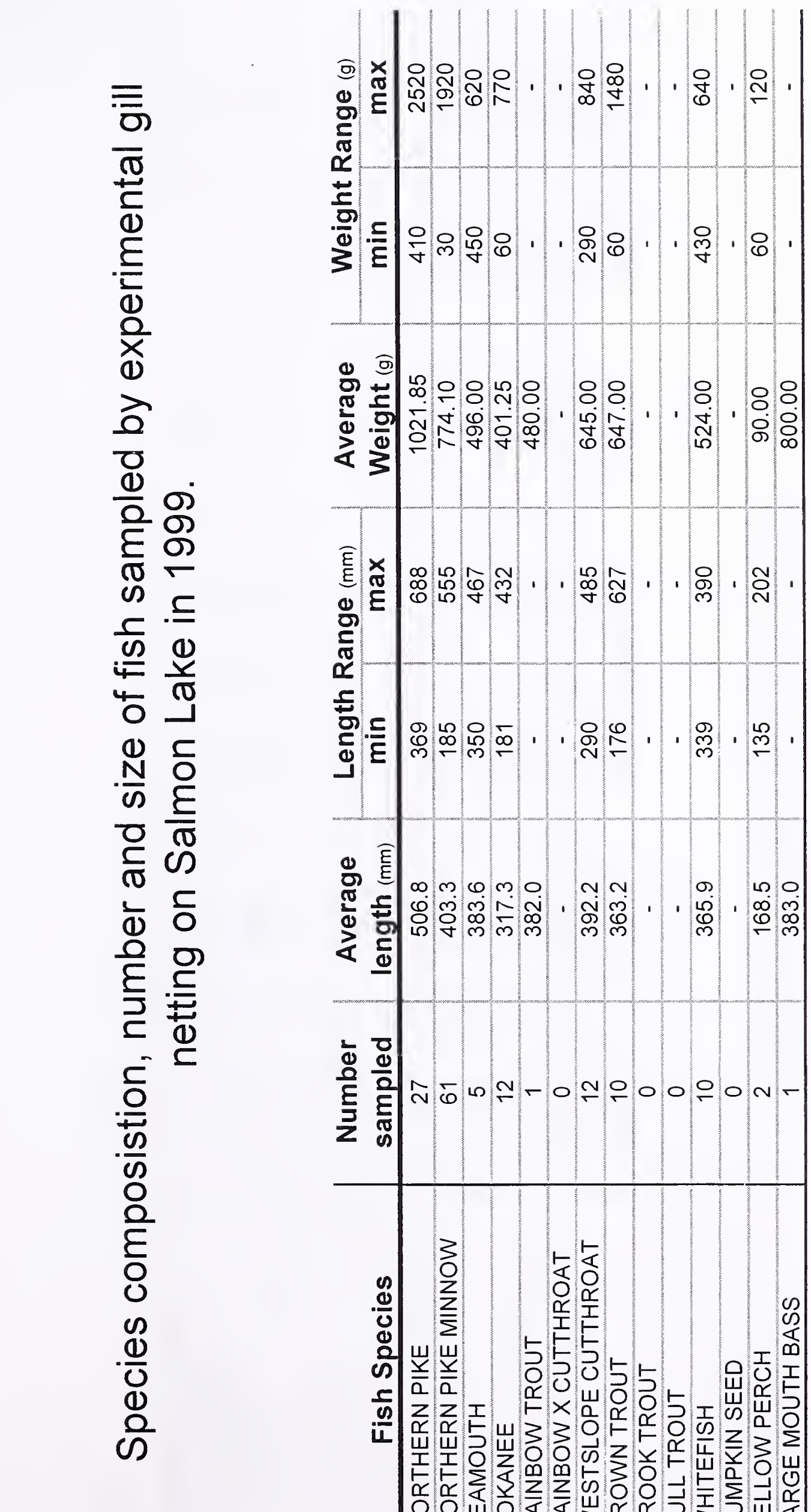

Ð

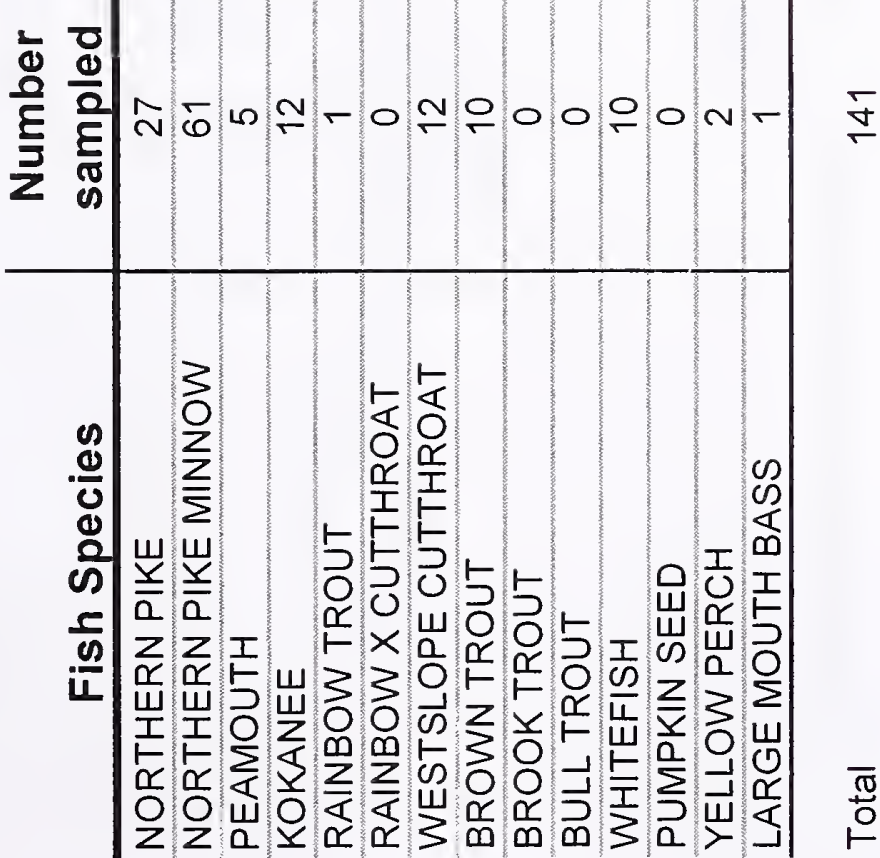




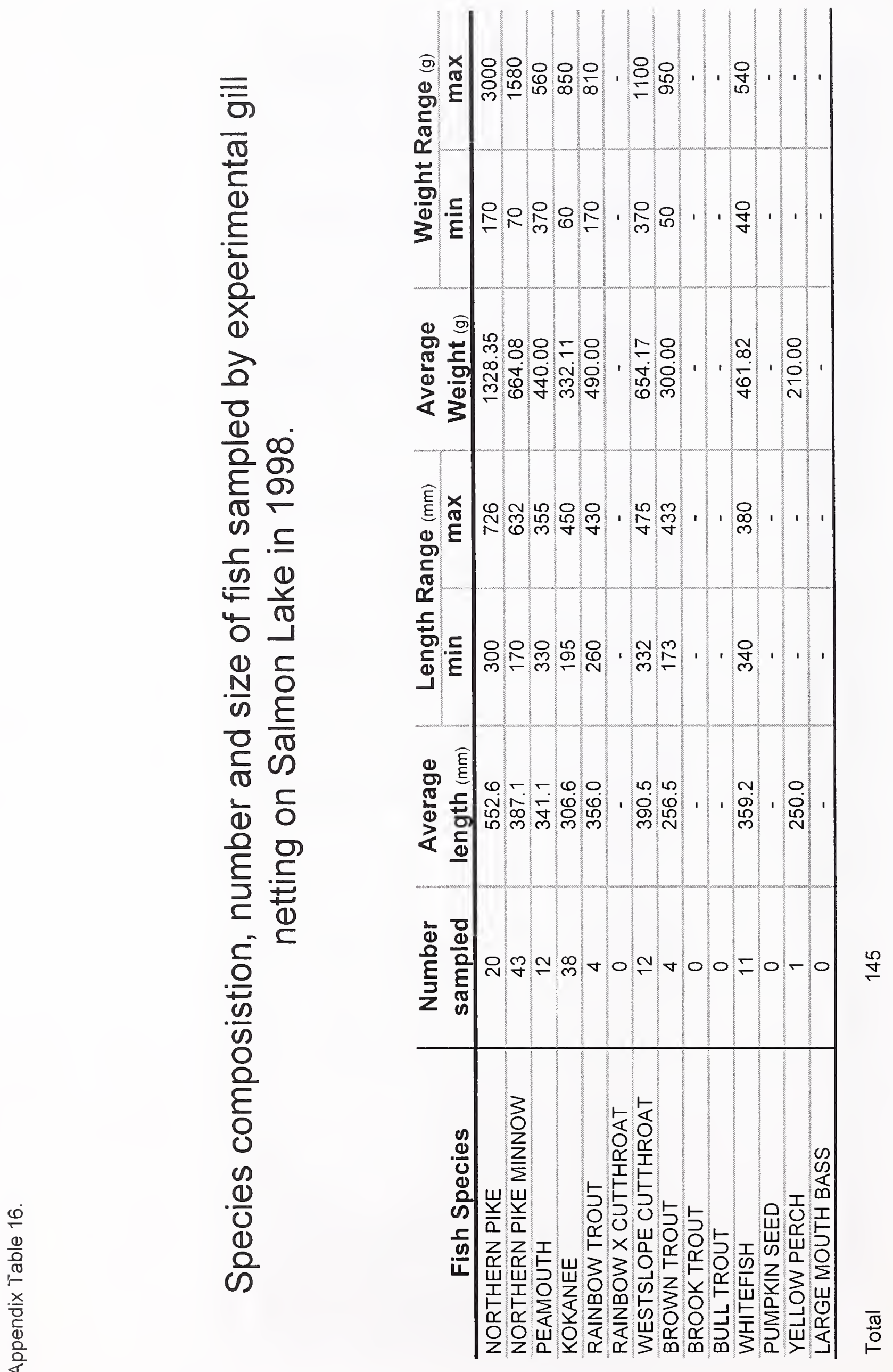



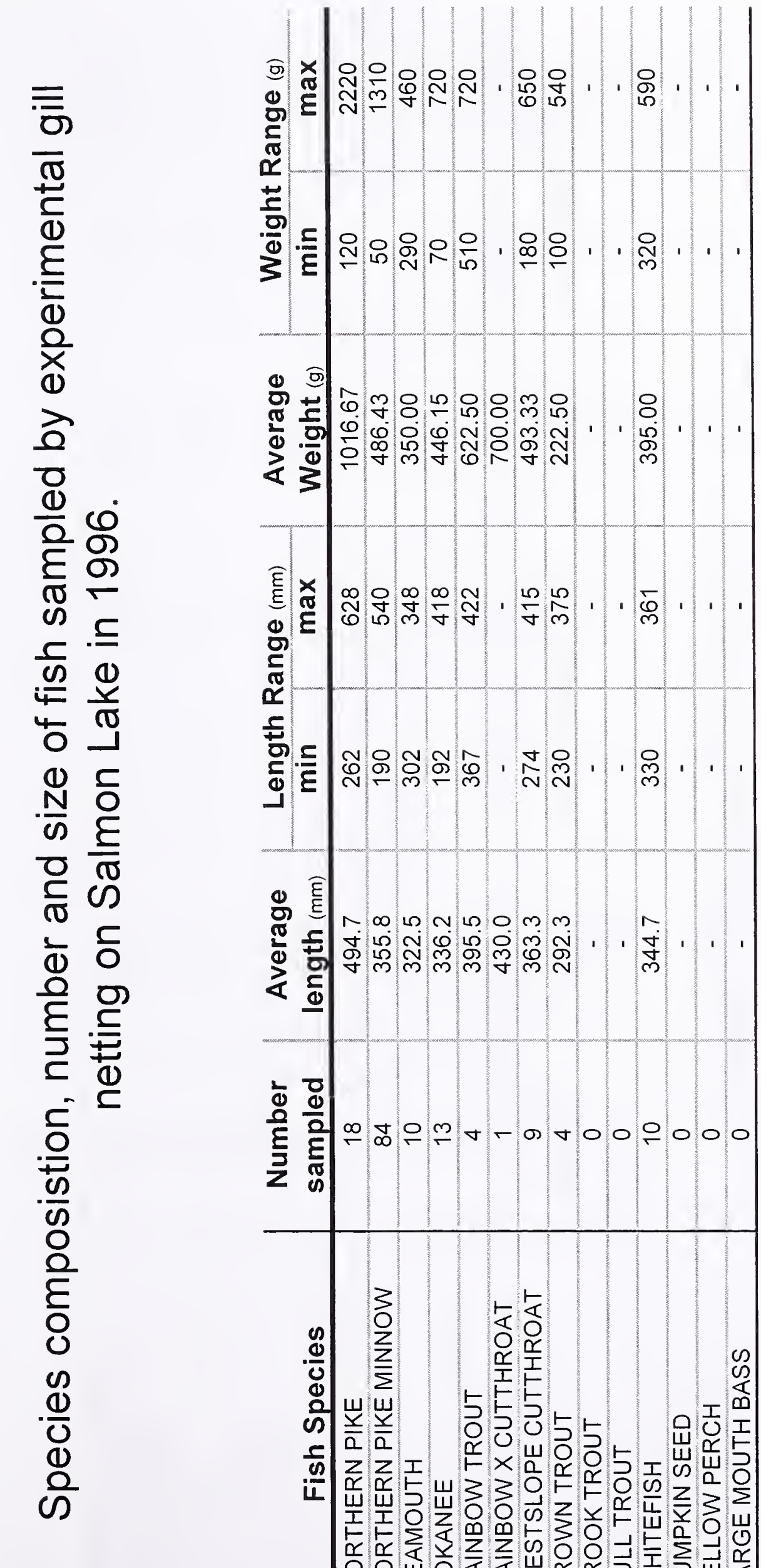

L
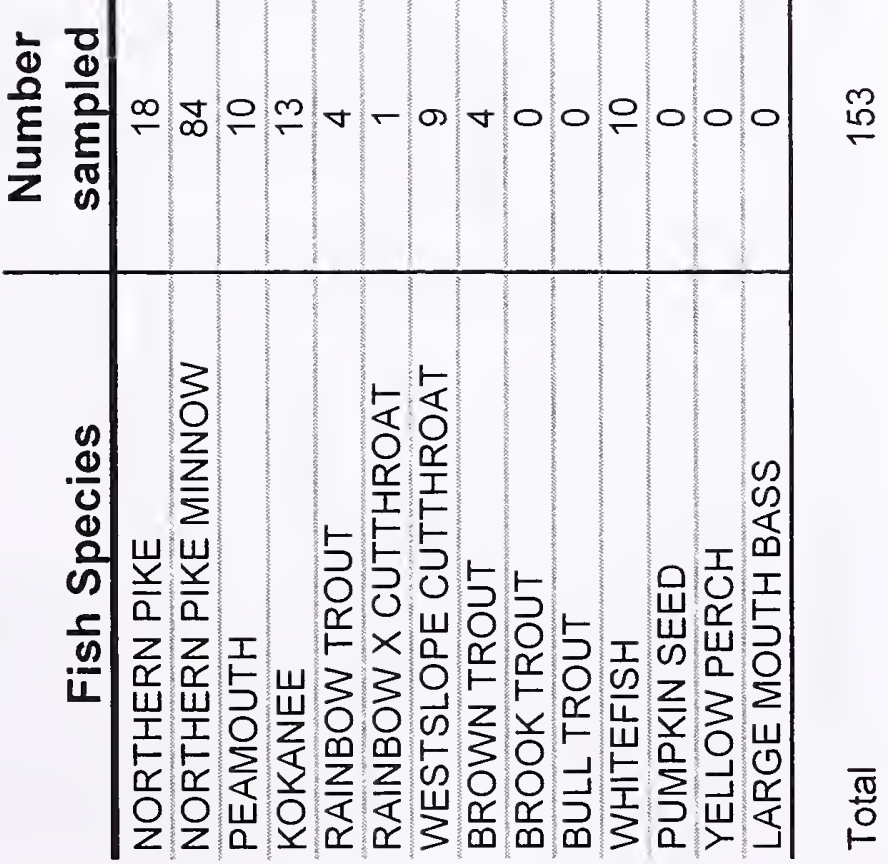


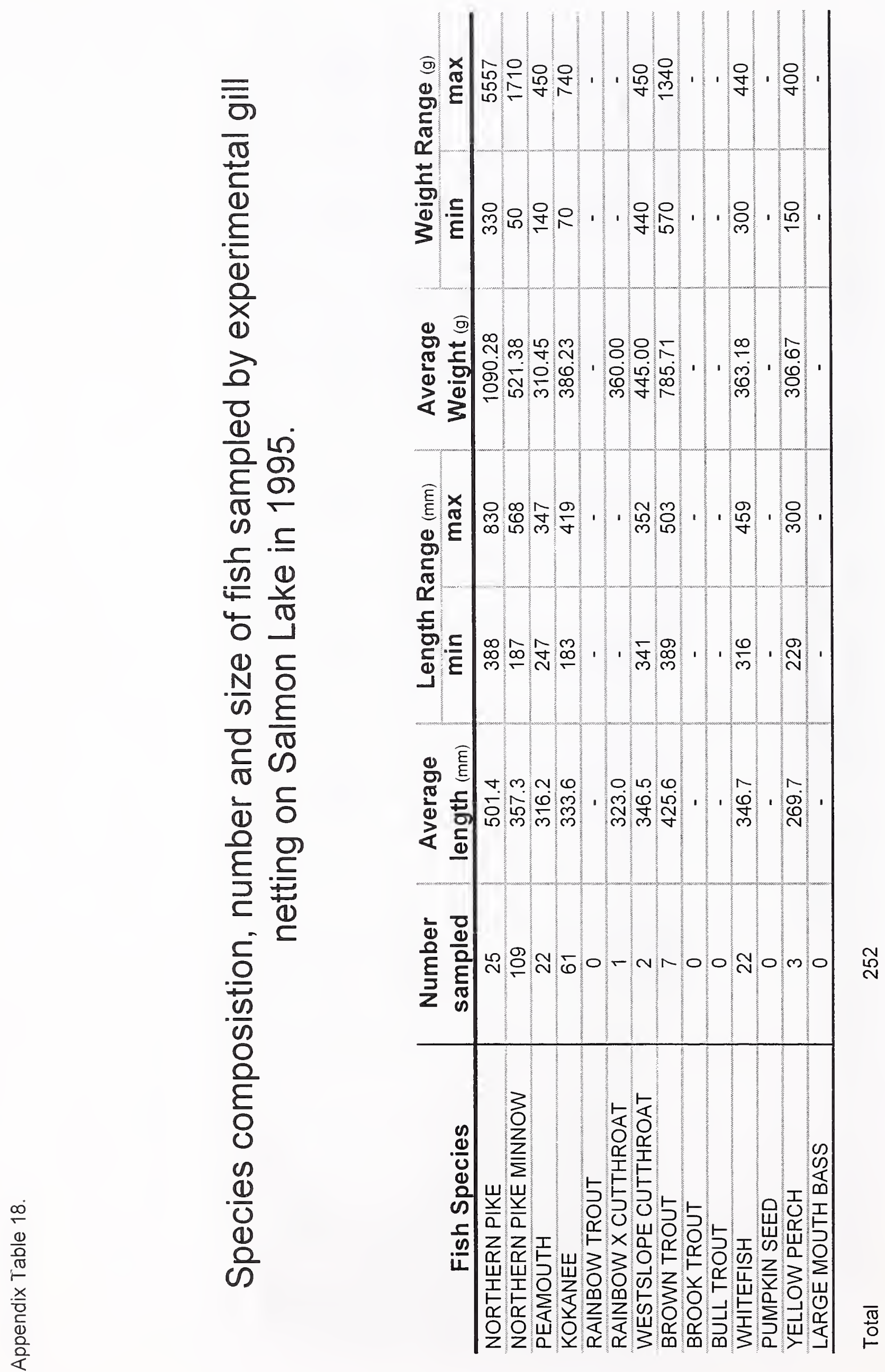



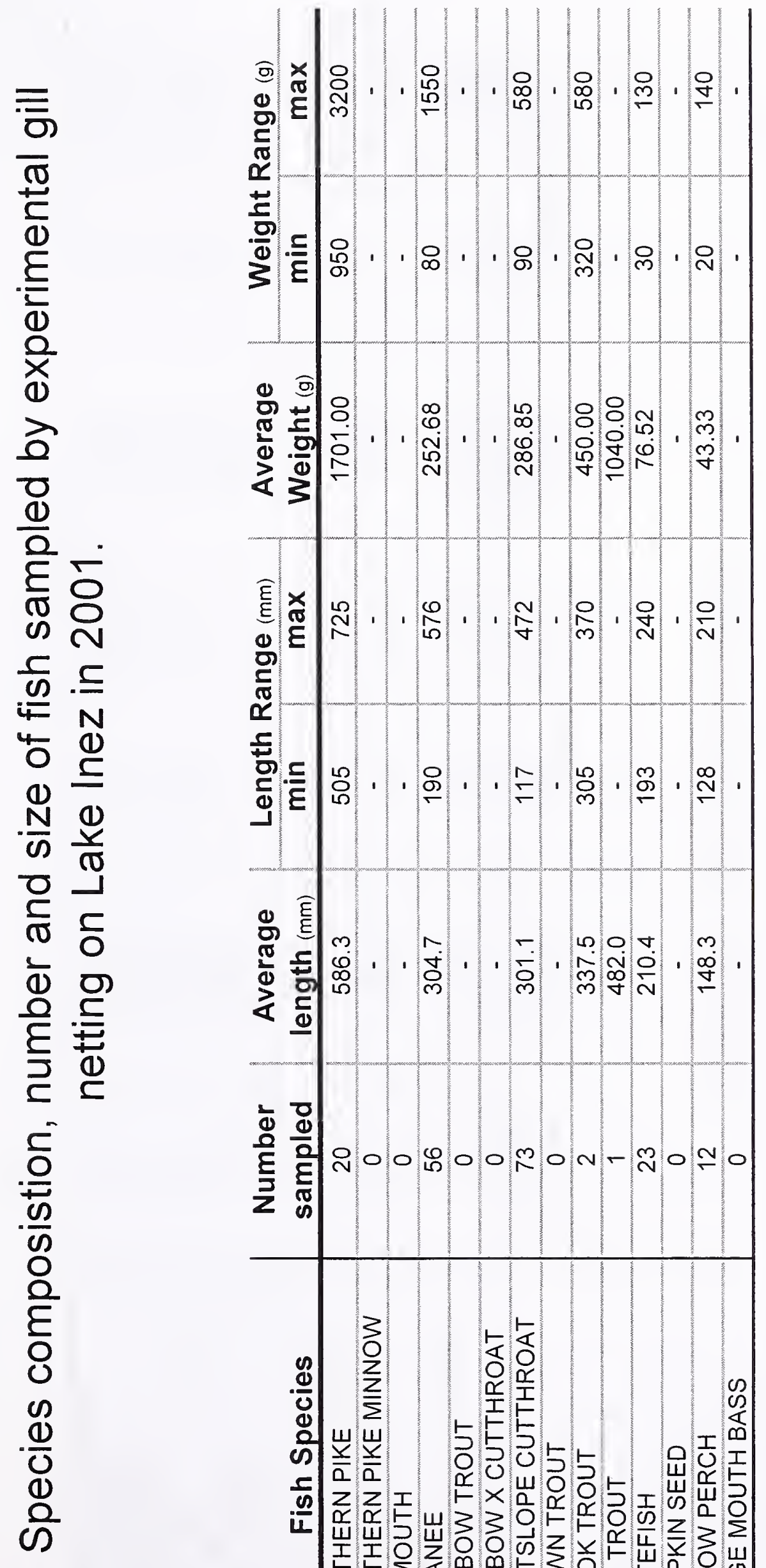

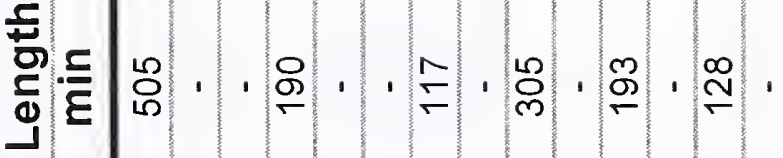




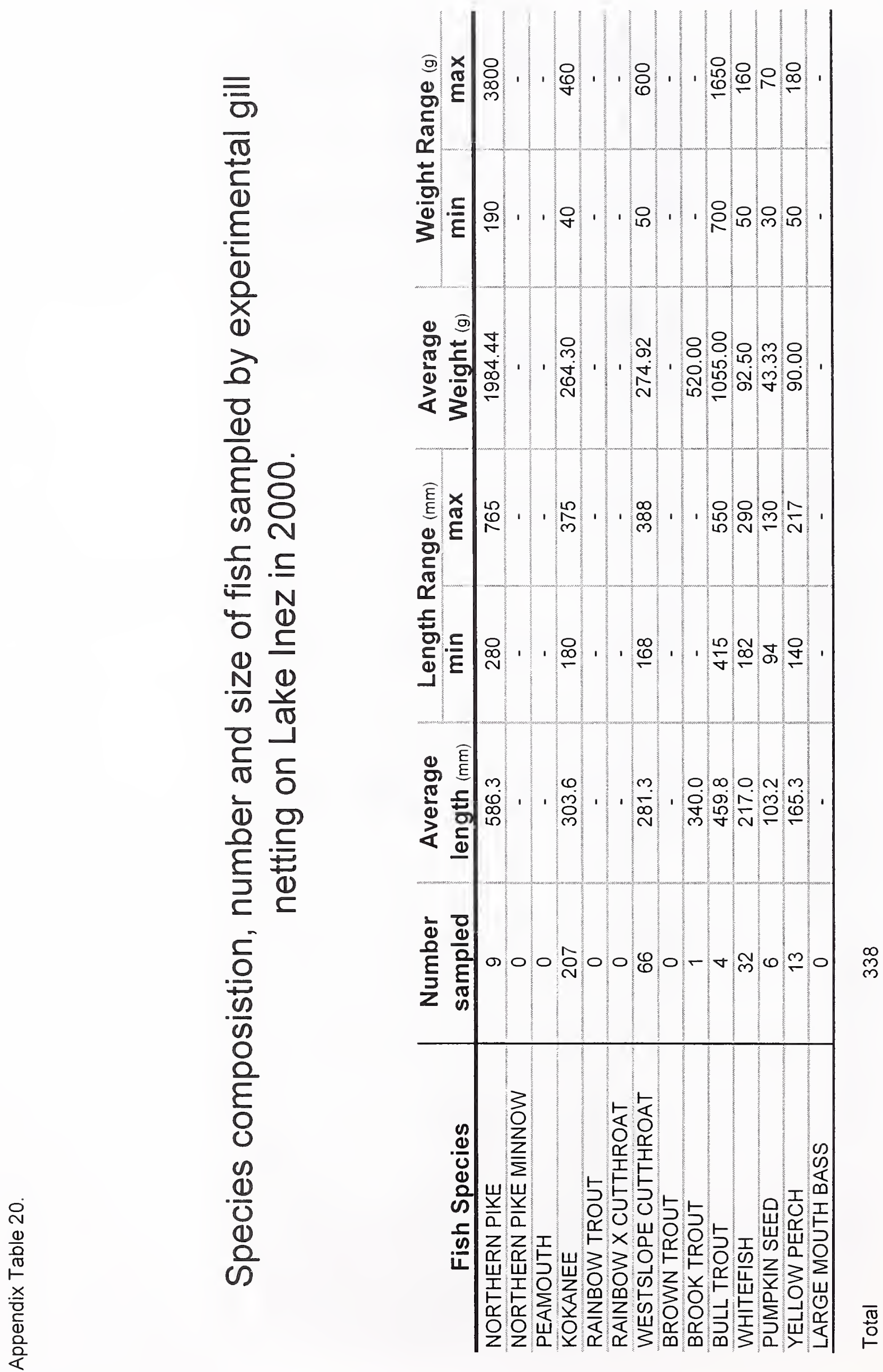



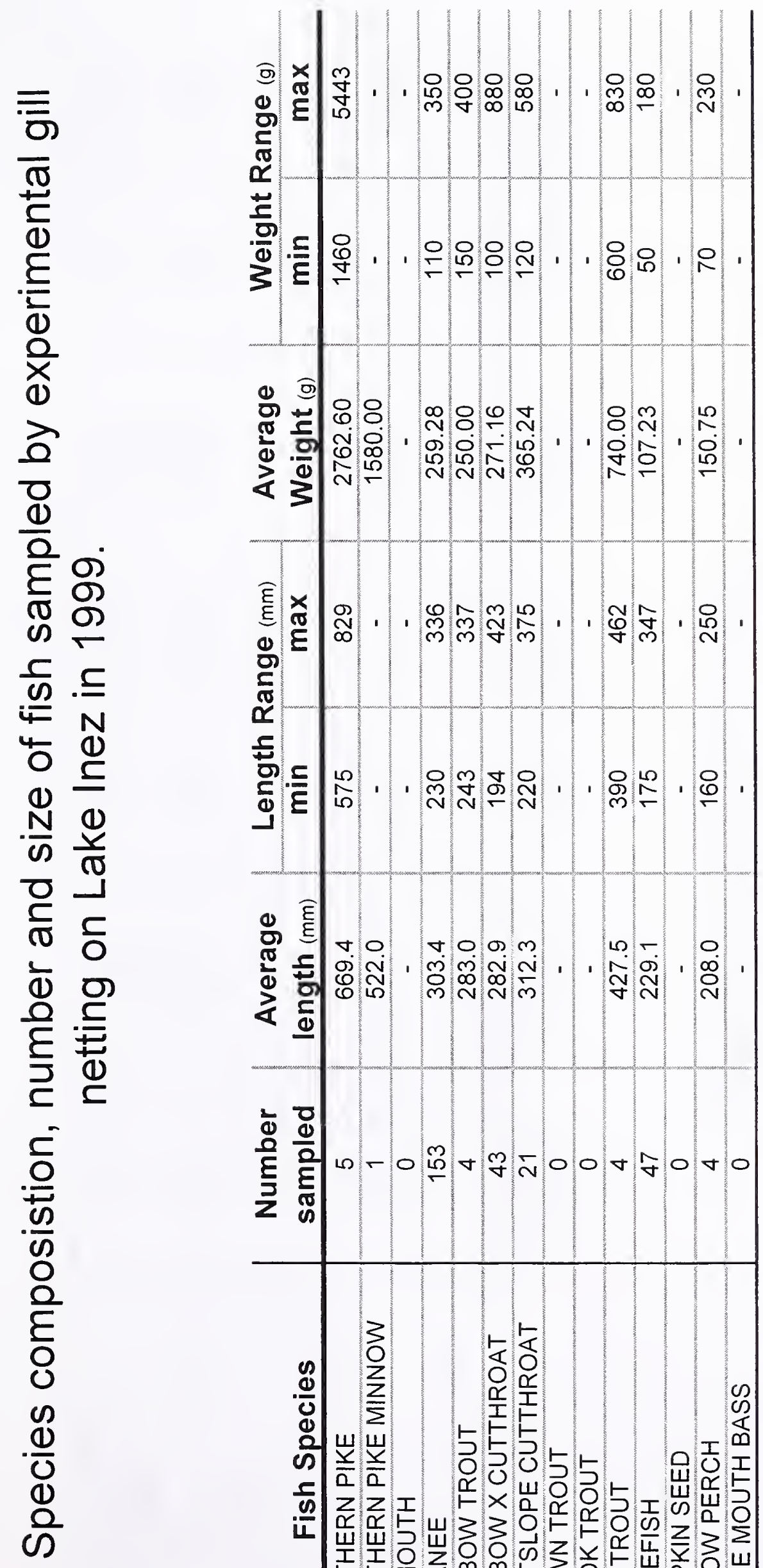

苟
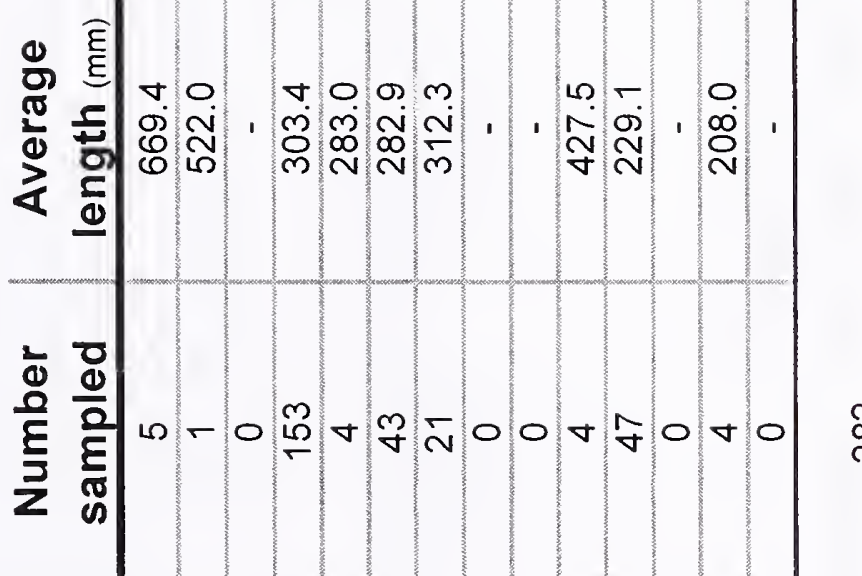

$\stackrel{\sim}{\sim}$

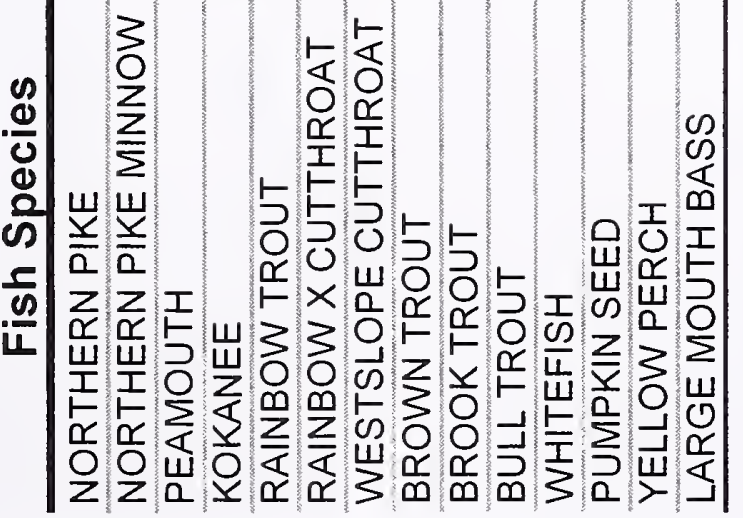




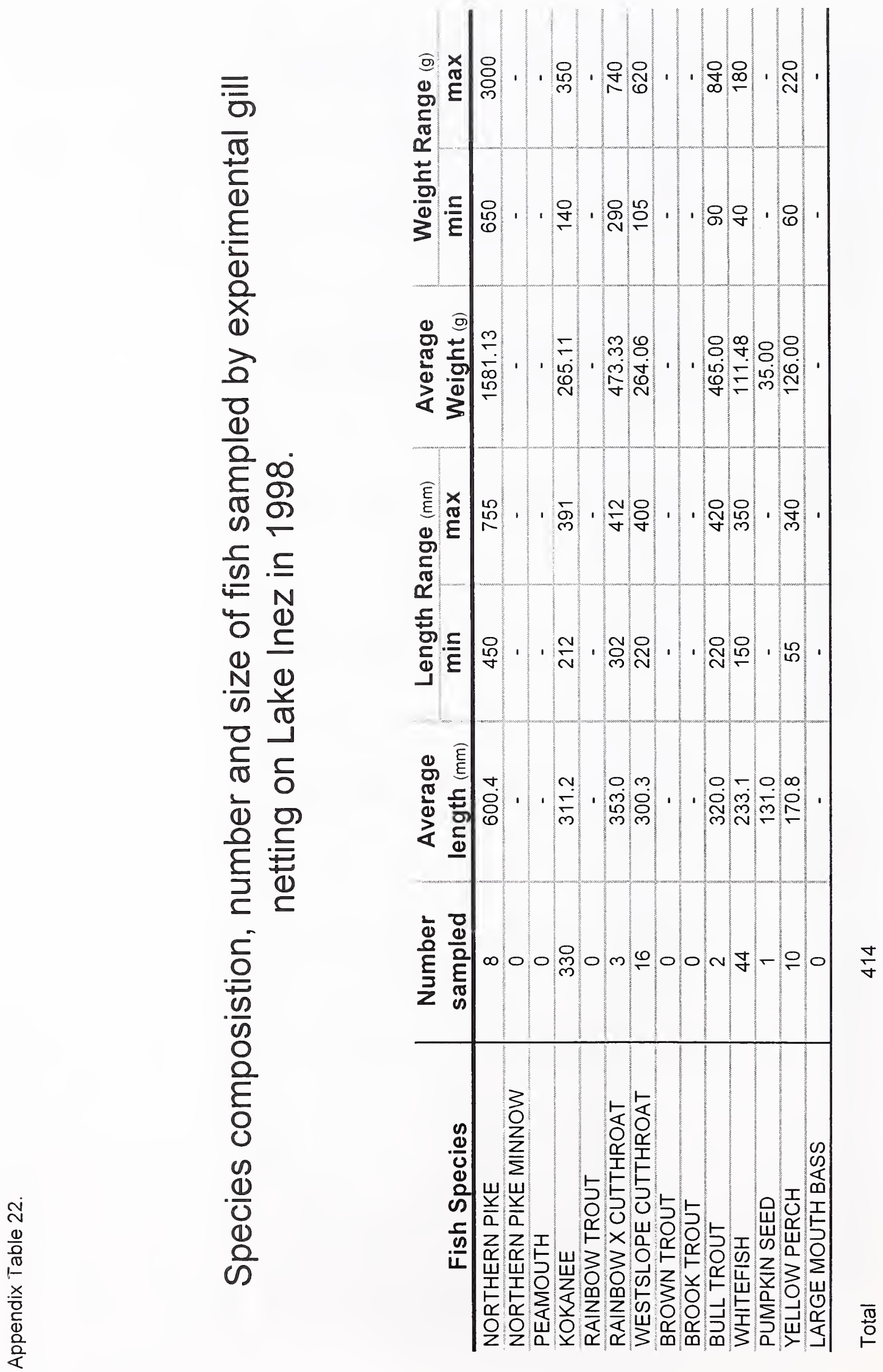



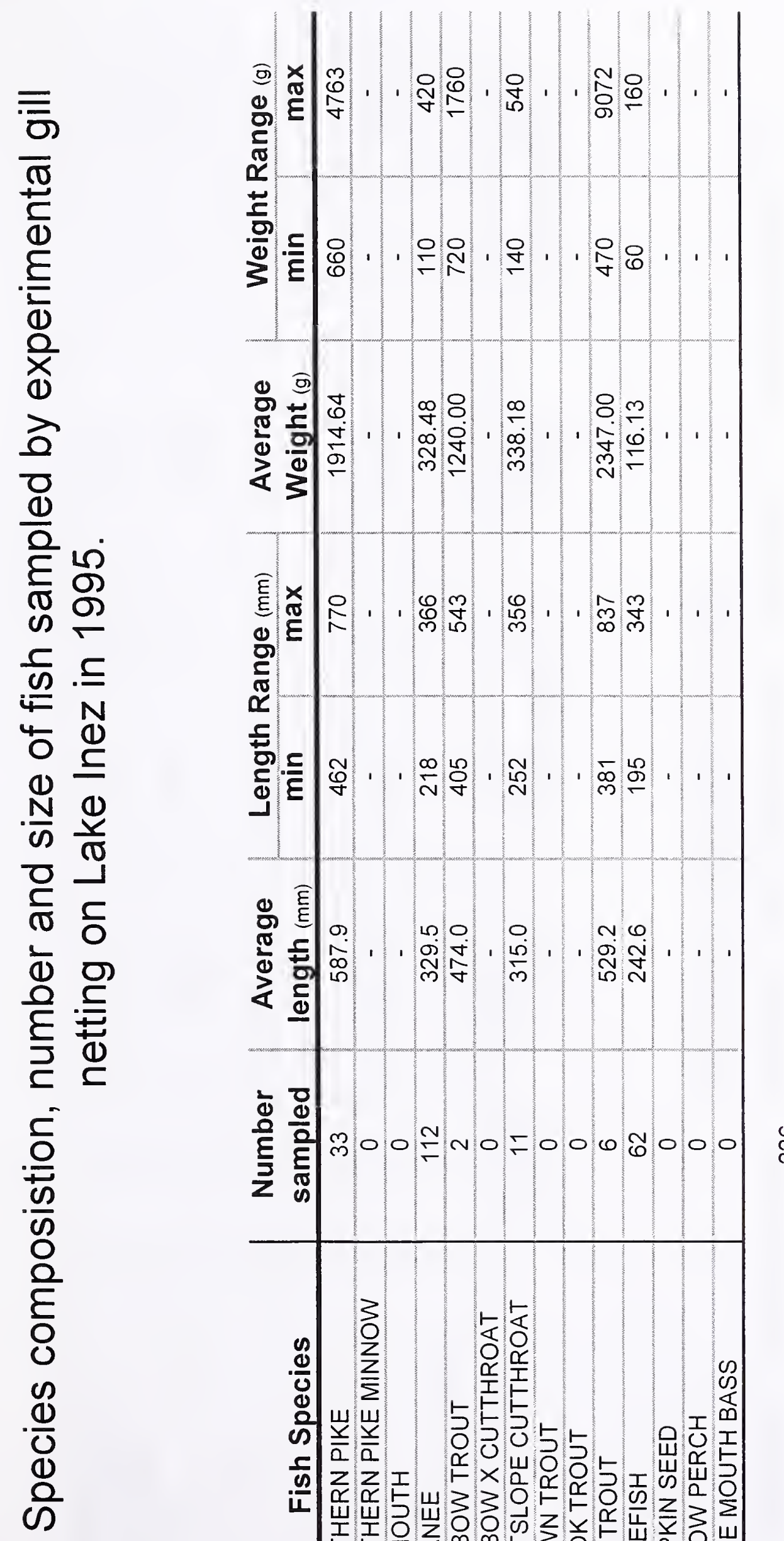

$\stackrel{\mathscr{N}}{N}$

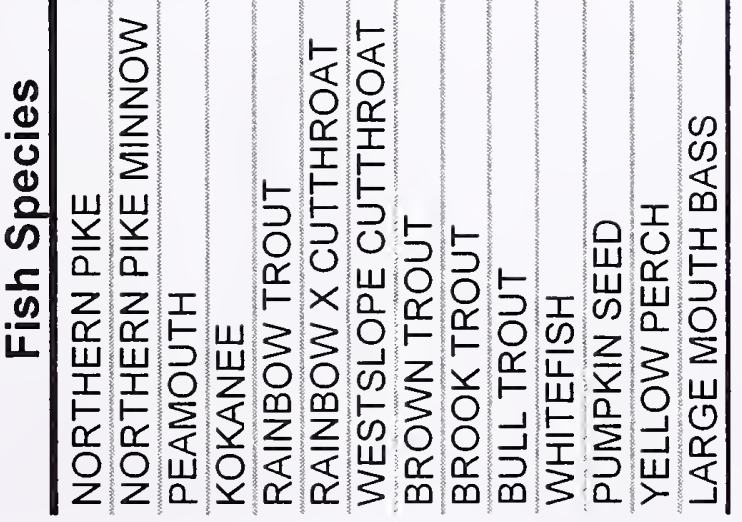




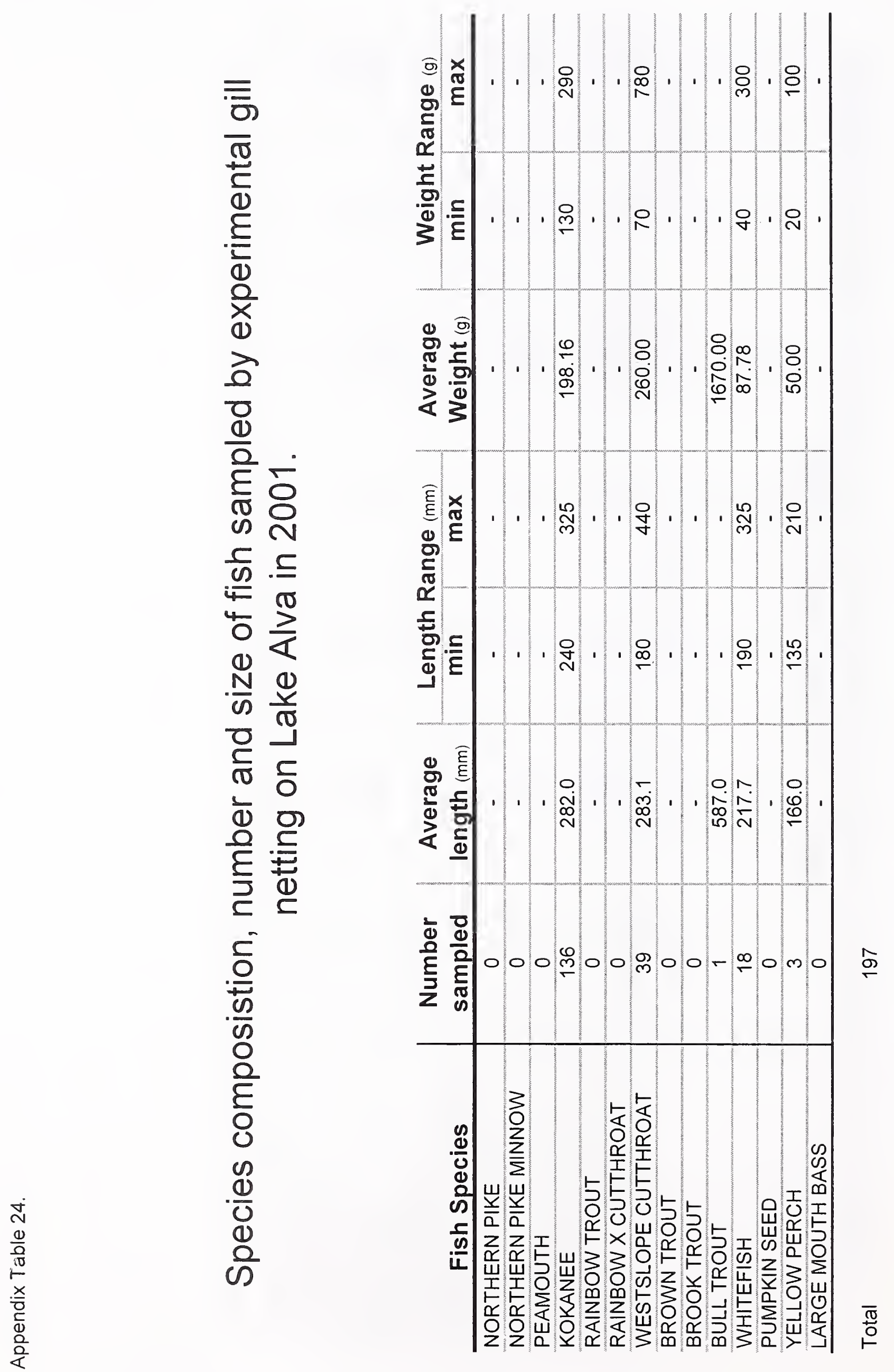



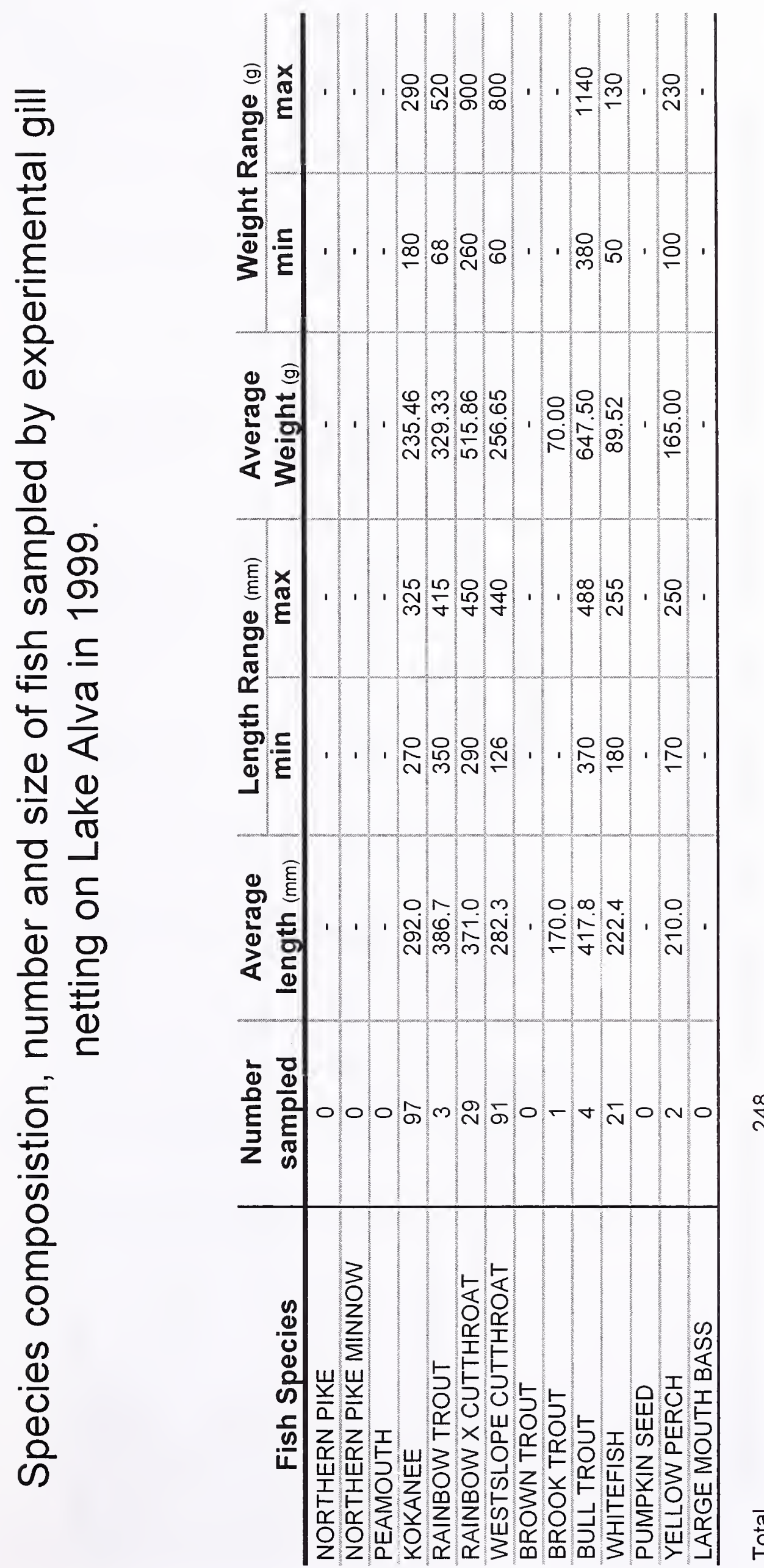


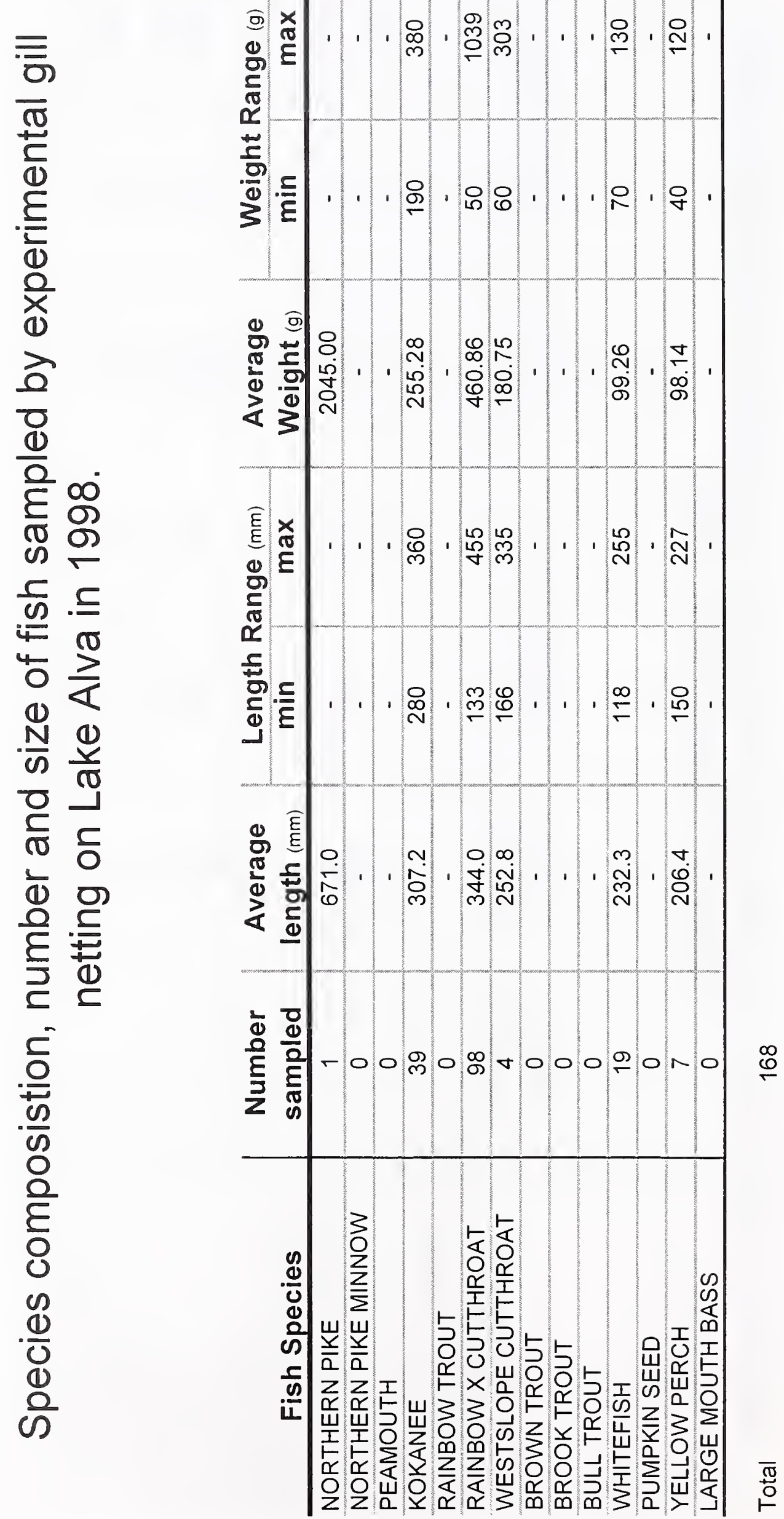



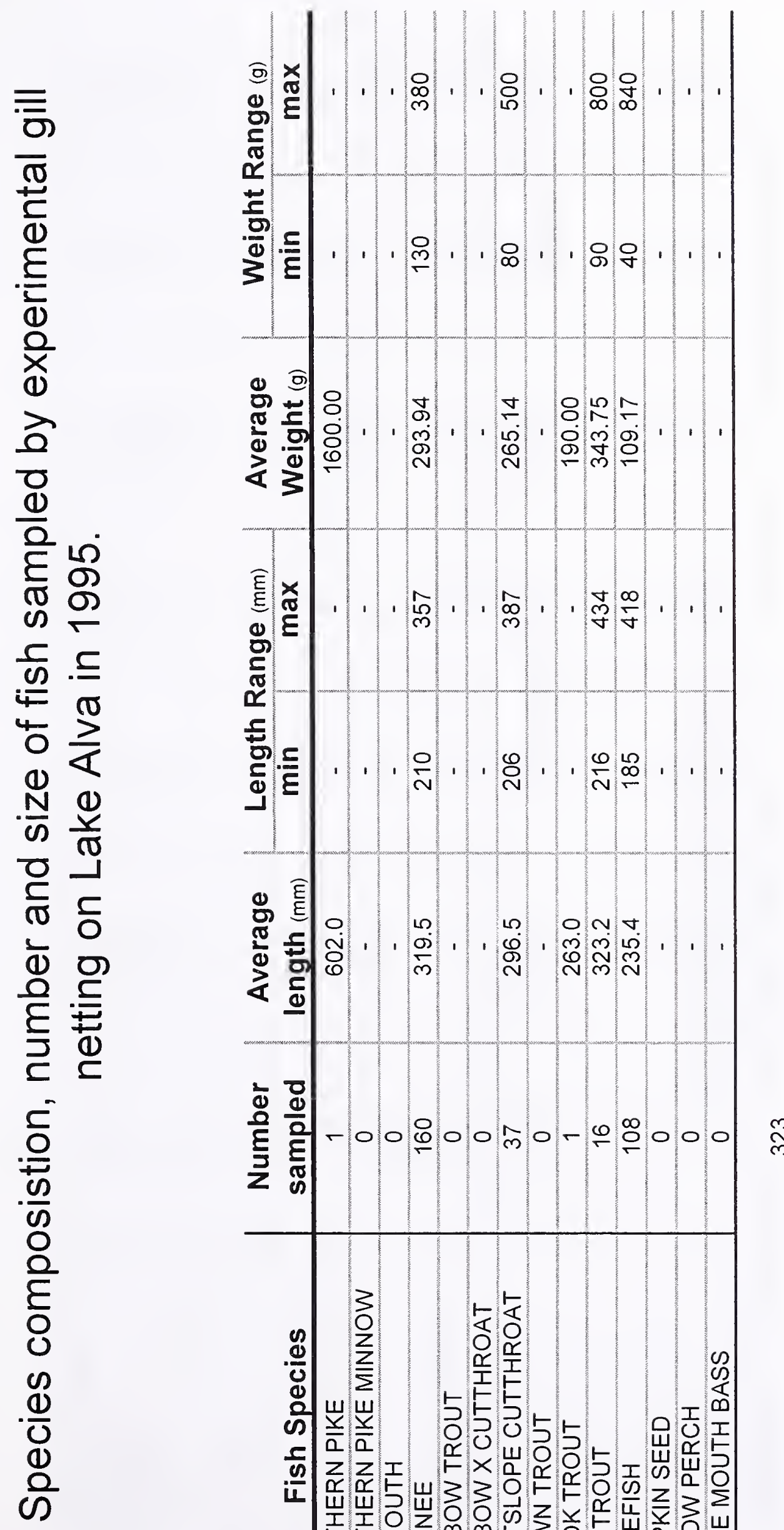

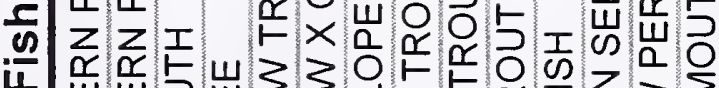

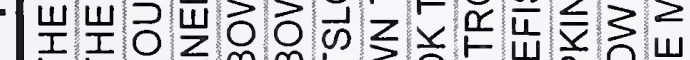

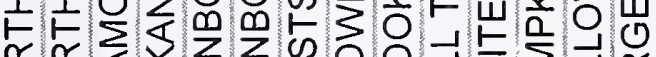
家 


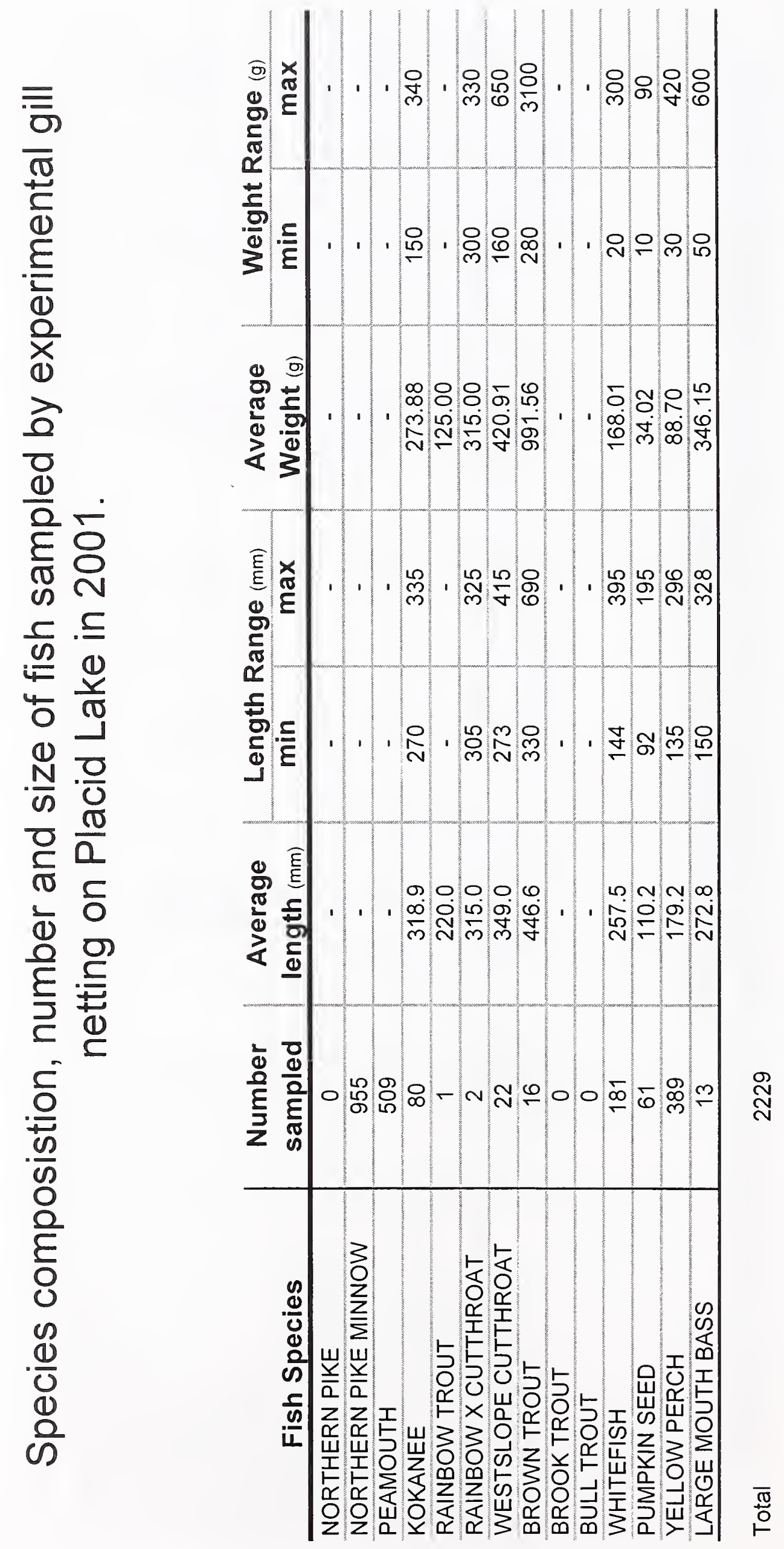




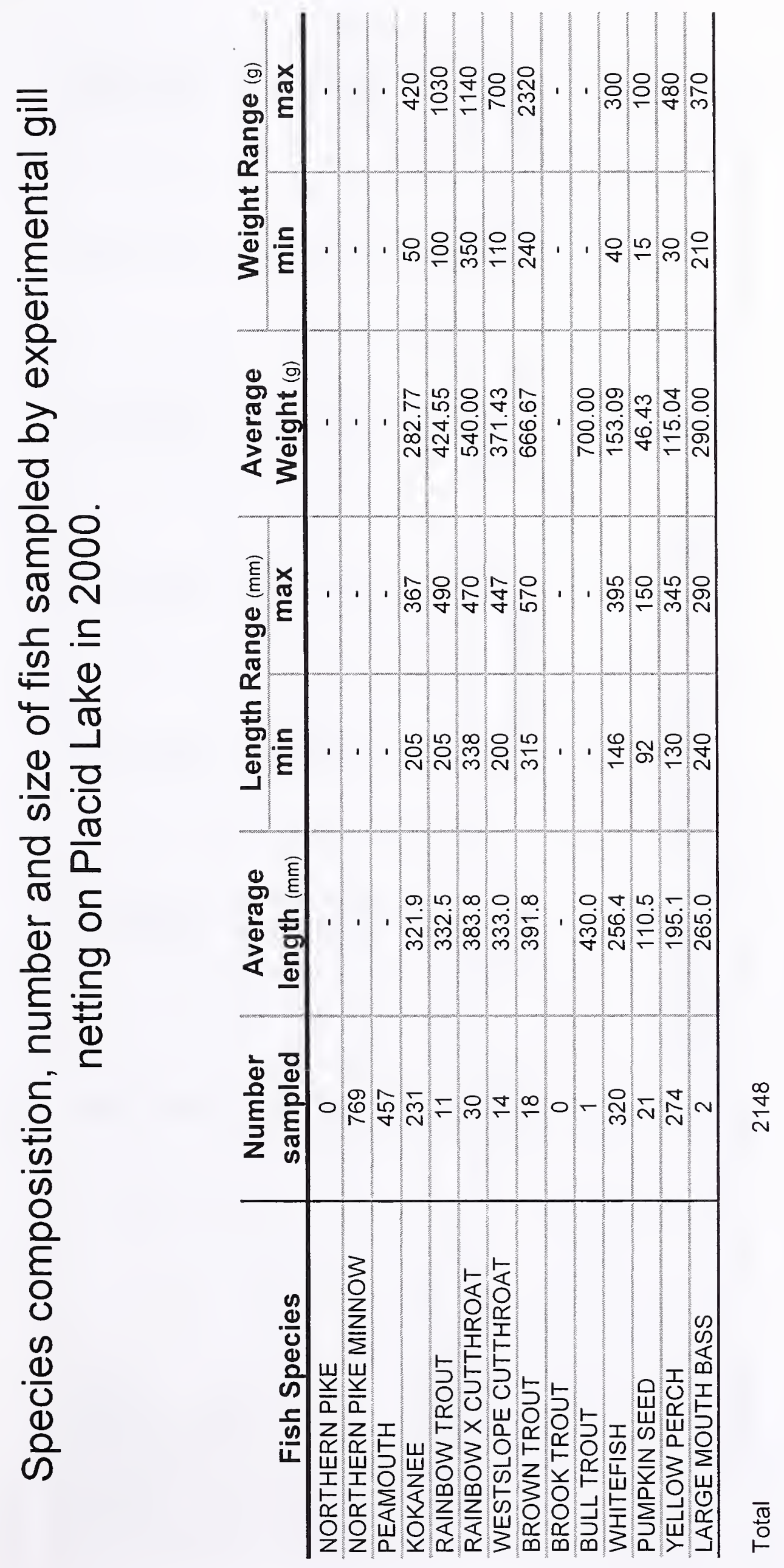




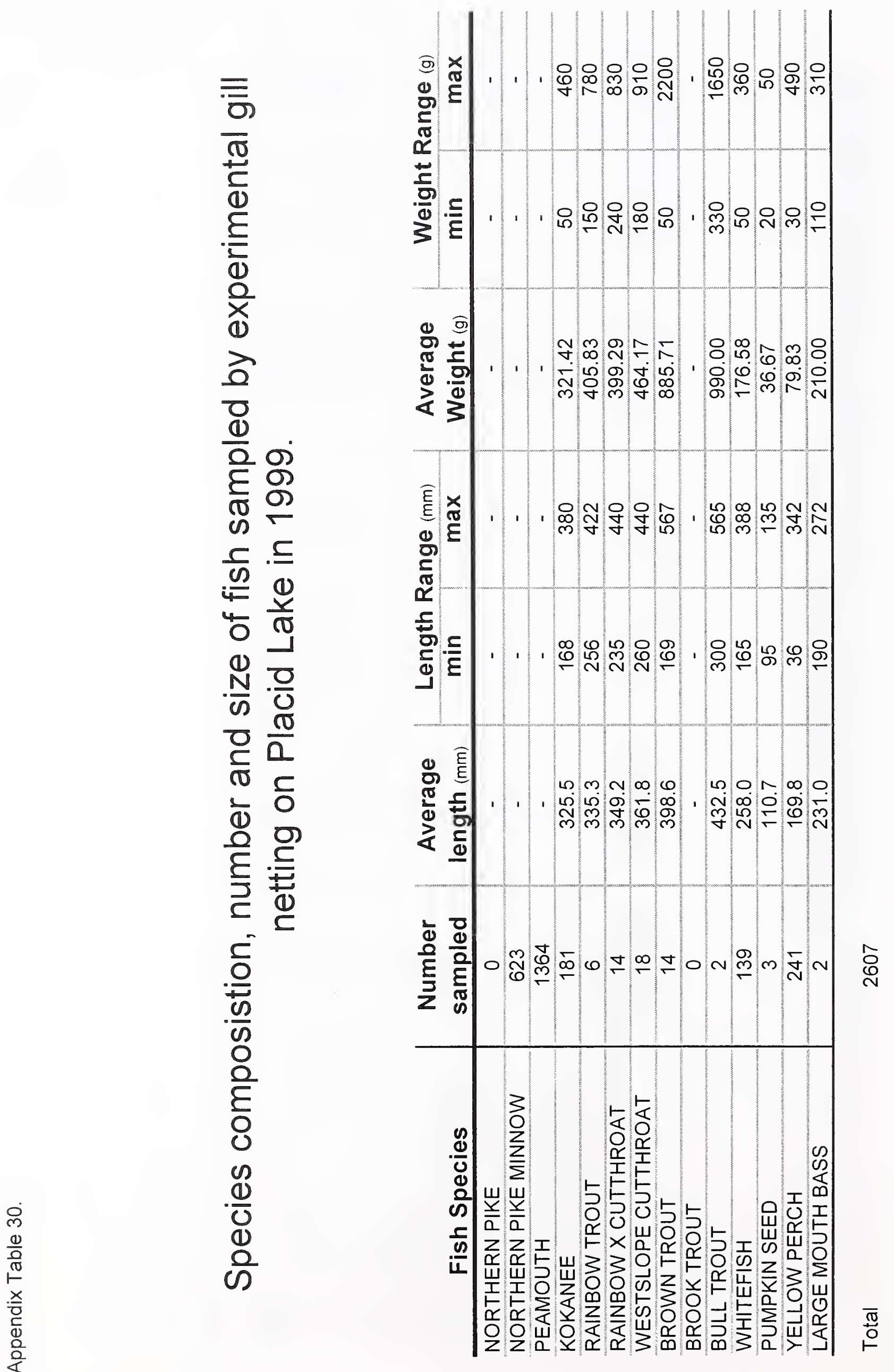




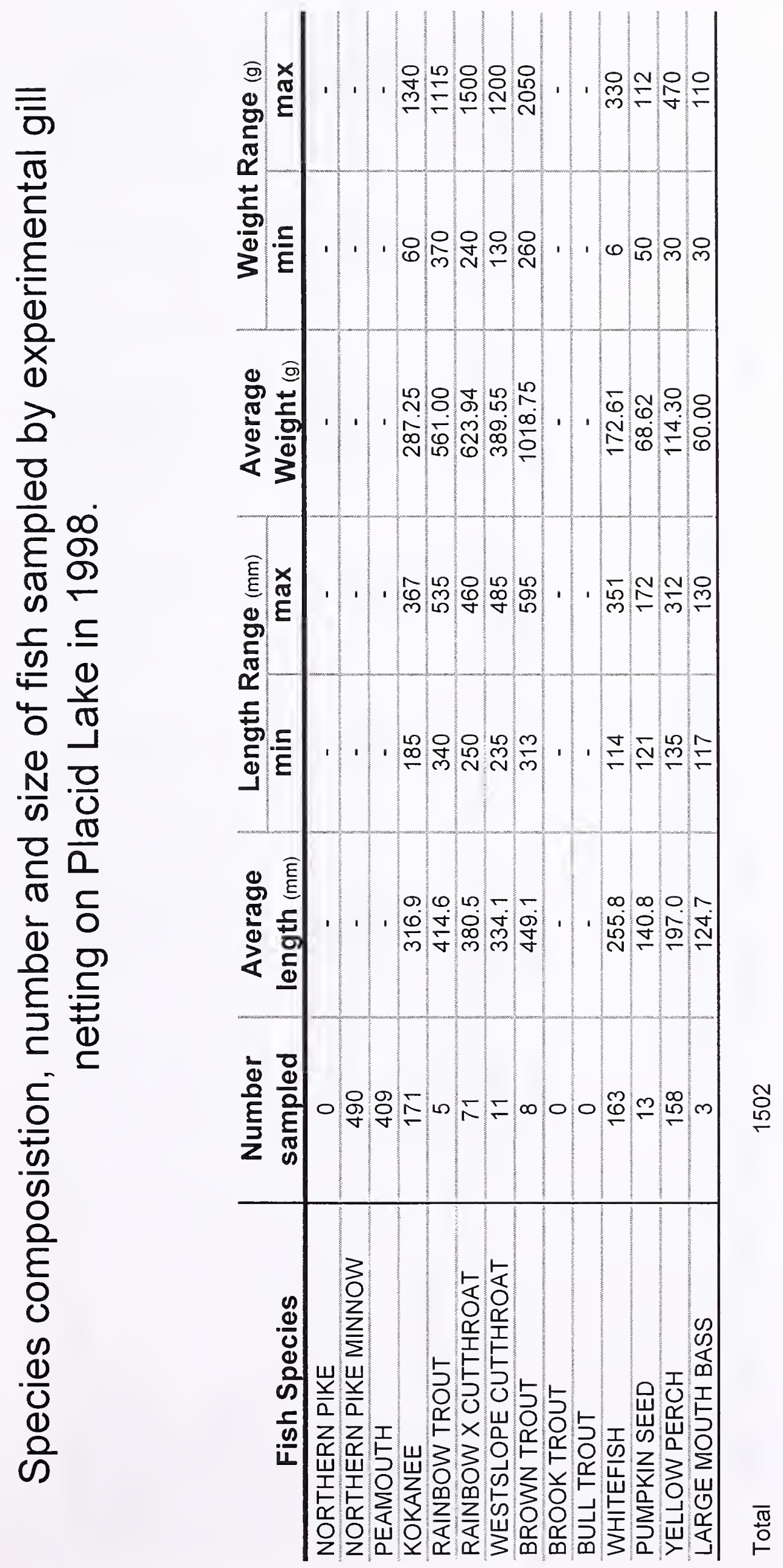




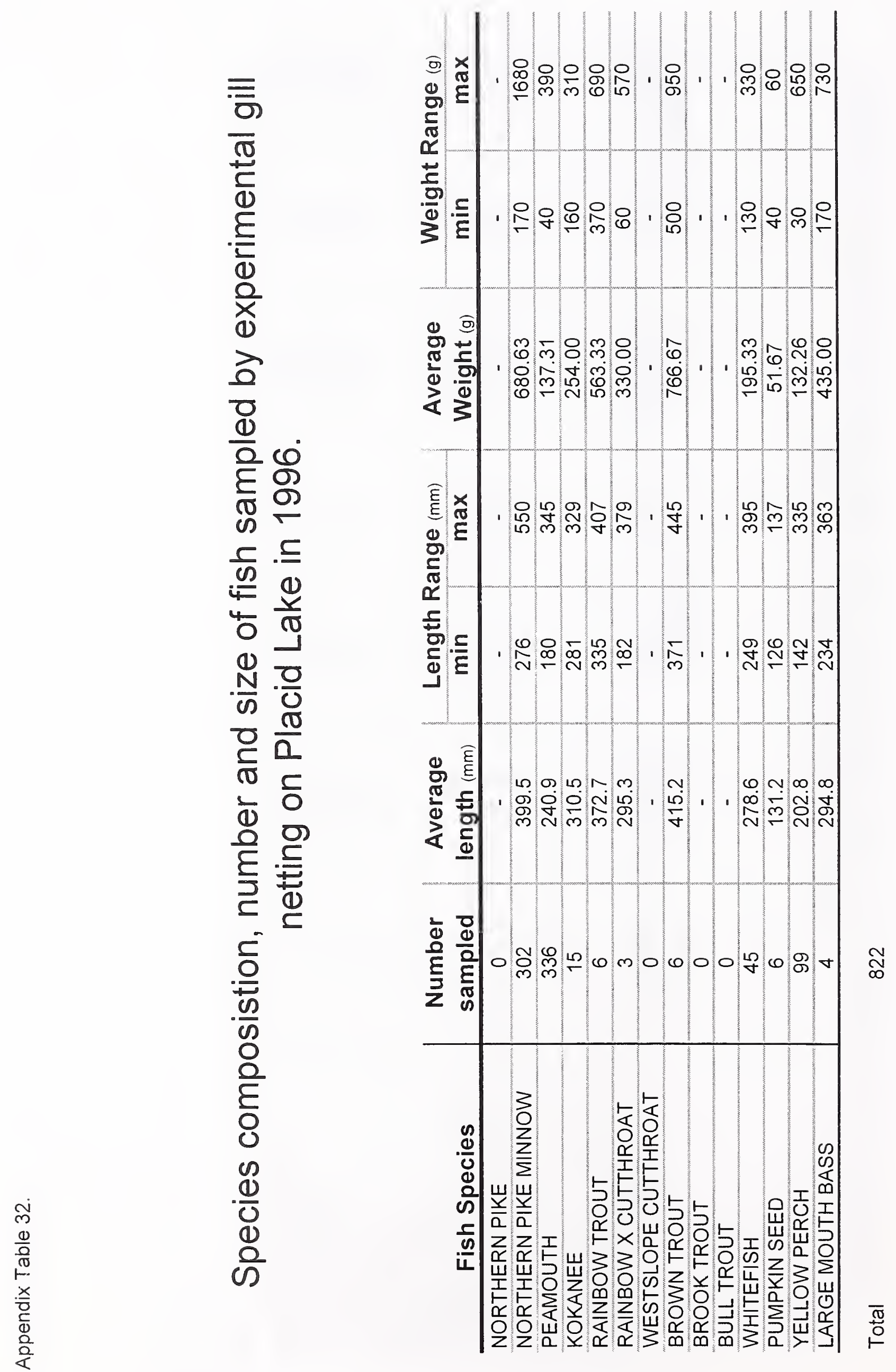



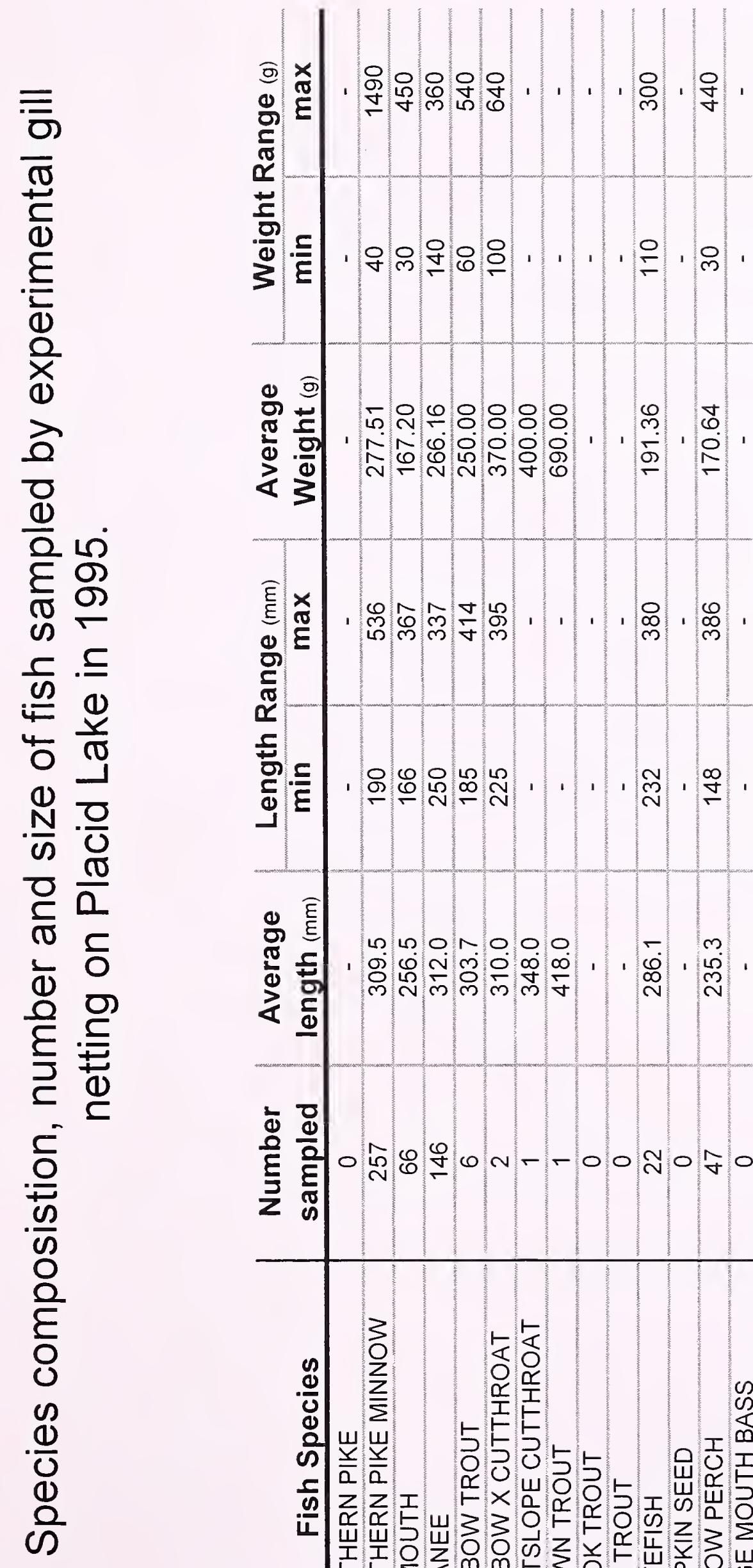

.

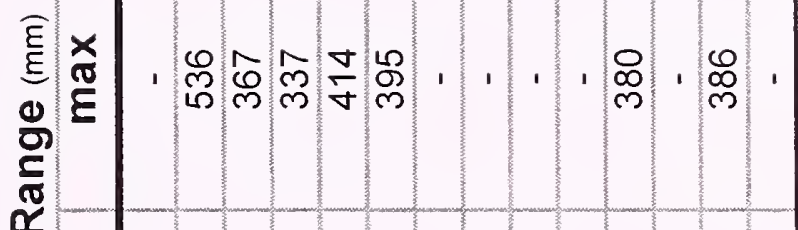

둥

卤

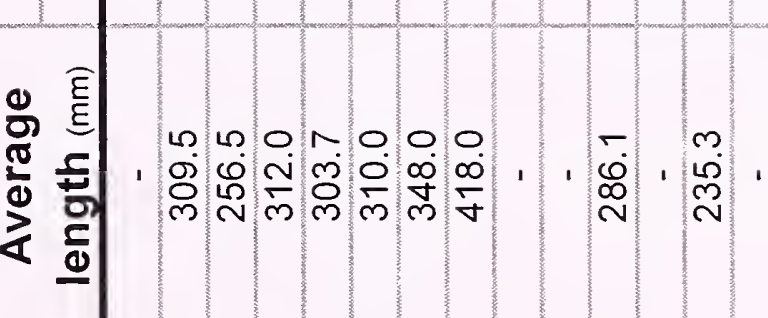

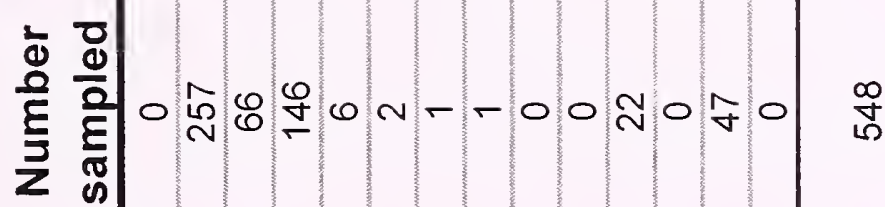

$m$
$m$
$\frac{0}{0}$
$\frac{0}{\sigma}$
$\frac{x}{0}$
$\frac{x}{0}$
0
0 


